\title{
150 years of plans, geological survey and drilling for the Fréjus to Mont Blanc tunnels across the Alpine chain: an historical review
}

\author{
Giorgio V. Dal Piaz (1) \& Alessio Argentieri (2)
}

\begin{abstract}
Since Roman age, people living on both sides of the Alps had been seeking different 'north-west passages', first overriding the mountains and then moving under them. The first idea of a tunnel under the Mont Blanc was envisaged by de Saussure in 1787. In the $19^{\text {th }}$ century a growing railway network played a fundamental role for the Industrial Revolution, but was hampered for the southern countries by the barrier of the Alps, so that modern transalpine railways became essential for the Reign of Sardinia. This paper presents an historical review of first suggestions, projects, field survey, failed attempts and successful drilling works across the Alps, from the Frejus (1871), San Gottardo (1882) and Simplon (1906) railway tunnels to the Grand St Bernard (1964) and Mont Blanc (1965) highway tunnels, relived within the advances of regional geology and mapping. The Fréjus tunnel was conceived by Medal, projected by Maus between Modane and Bardonèche and approved by a ministerial commission, but it was abandoned due to the insurrection of 1848. Later, it was taken up again, developed by Sommeiller, promoted by Cavour himself, and approved in 1857. Technical management was assigned to Sommeiller, Grattoni and Grandis. Fréjus was the first, longest and innovating railway tunnel in the world: drilling began in 1857 and ended in December 1870, thanks to a new drilling machine powered by compressed-air. Its inauguration took place on September 1871. When the Fréjus drilling was still in progress, John Fell built a mountain railway between Piedmont and Savoy, through the Mont Cenis, following the Napoleonic road. During its four years of work (18681871 ) it managed to transport about 100,000 travellers, but it was forced to close down when the Fréjus railway tunnel was opened. The geological advances and mapping in the Western Alps by the mid-19 $9^{\text {th }}$ century provided information and reliable tools for better planning of great engineering works, but tunnel designs were not always based on a geological survey: the main exceptions were represented by GIORDANO (Gottardo, 1881) and BARETTI (Mont Blanc, 1880). The former tunnel was drilled, the latter was not accomplished, as other projects were instead preferred across the Western Alps, Colle di Tenda (1898) and then Simplon (1906). After new hopes, the geological study on four project tunnels under the Mont Blanc by Franchi, Kilian and Jacob (FRANCHI et alii, 1908), and further disappointments, decisive moves to achieve the underground connection between Courmayeur and Chamonix were made by Dino Lora Totino who requested a project to Vittorio Zignoli. Meanwhile, a geological survey for radioactive minerals was promoted by CNRN on the Italian side of the Mont Blanc: field work was performed by Baggio and his staff, and their best result was the discovery of mylonitic-cataclastic shear zones crossing the tunnel route. Their work continued during the drilling inside the Italian part of the Mont Blanc motorway tunnel, started in 1959 and ended in 1962: systematic geological, structural and application data were acquired by Mezzacasa during excavation and studied by Baggio, Elter and Malaroda, whereas the French side was surveyed by Gudefin and studied by Vittel and others after the end of excavation. This paper is meant to be a grateful tribute to all scientist and technicians that, thanks to geological studies, maps and sections, allowed deep mountains to be metaphorically transparent, thus making it easier and safer to physically go through them.
\end{abstract}

(1) Società Geologica Italiana, Sezione di Storia delle Geoscienze.

(2) Città Metropolitana di Roma Capitale, Dip. VI- Servizio 3 Geologico e difesa del suolo, protezione civile in ambito metropolitano - Società Geologica Italiana, Sezione di Storia delle Geoscienze. Corresponding author e-mail: gv.dalpiaz@gmail.com
Geology and tunneling have close interactions and mutual benefits. Preventive geology allow to optimize the technical design, reduce costs and minimize bitter surprises. Conversely, systematic survey during excavation of deep tunnels has provided innovative data for the advance of geosciences.

\section{KeY words: history of geosciences, Fréjus and Mont Blanc, transalpine tunnels, Western and Central Alps.}

\section{INTRODUCTION}

The ancient roads which ran from Rome to the provinces of the Roman Empire formed a vast network of paved surfaces-works of extremely advanced civil engineering, some of which led over the Alps with safe, permanent bridges and viaducts, except for the winter closure of high-altitude passes (Agavit Pasouino, 1970). Tito Livio ( $A b$ urbe condita) immortalised the daredevil crossing undertaken by the Carthaginian Hannibal Barca during the Second Punic War (218 B.C.), heading an army of tens of thousands of soldiers and 37 elephants. Two thousand years later, Napoleon Bonaparte succeeded in the arduous task of crossing the Gran San Bernardo Pass $(2,473 \mathrm{~m}$ a.s.l.) and later chose the Col du Mont Cenis (Moncenisio, 2,083 $\mathrm{m}$ a.s.l.) where, from 1803 to 1805 , built a large-scale pass with many hairpin bends and gradients suitable for cavalry and heavy artillery (LESCA, 1993).

During the first half of the $19^{\text {th }}$ century, journeys and transportation were innovated thanks to the development of railways, which played a fundamental role in spreading the Industrial Revolution (SELLARI, 2011). The first railway was English, $42 \mathrm{~km}$ long, and was built to transport coal from the Darlington mines to the port of Stockton-on-Tees: inaugurated in 1825, it used 'the first one', the steam engine built by George Stephenson. The first passenger line, 48 $\mathrm{km}$ from Liverpool to Manchester (1830), was a success and favoured the rapid development of English, European and Italian railways. Before the Unity of Italy, the Reign of the Two Sicilies had built a railway from Naples to Portici $(7.64 \mathrm{~km})$, inaugurated on October $3^{\text {rd }}, 1839$ by Ferdinando II di Borbone: this was followed by others connecting Milan-Monza (1840), Padova-Mestre (1842), Pisa-Livorno (1844) and many others, to the $267 \mathrm{~km}$ of the 'Lombardisch-Venetianische Staatsbahn' (Milan-Venice), completed in 1857.

The problems posed by the barrier of the Alps and crossing them with modern railways became essential for the modernisation politics of the Reign of Sardinia and then for the young Reign of Italy (Collotti \& Collotti Psichel, 1974; Romano, 1977). Among the various proposals 
discussed, Camillo Benso, Count of Cavour, thought that priority should be to link Turin with Chambéry, the capitals of Piedmont and Savoy, by means of a tunnel more than $12 \mathrm{~km}$ long under the frontier of Mont Fréjus (2,936 $\mathrm{m})$, between Bardonèche and Saint Michel-de-Maurienne (Modane). However, it should be noted that the names Mont Cenis, Cenisio and Moncenisio have often been used for the Fréjus railway tunnel: the two points are both located at the top of the Val di Susa, but they were more than $24 \mathrm{~km}$ away: the former was the pass and the latter the tunnel, first for rail and, from 1980, also for motorway traffic (Conte, 1863; Elie de Beaumont, 1871a, b; Cialdini, 2011). The Fréjus tunnel was the first railway tunnel in the world: excavations began in 1857 and the inauguration took place on September $17^{\text {th }}, 1871$. The Fréjus Tunnel was immediately used by the Indian Mail, the classic passenger and goods service between London and Bombay which, abandoning the long journey all the way round Africa, could now be the continental line from Calais to the Italian port of Brindisi and the Suez canal (LESCA, 1998).

The Fréjus enterprise was soon followed by other plans and the building of the large-scale railway tunnels of San Gottardo-St Gotthard (1882), Colle di Tenda (1898) and Sempione-Simplon (1906), at that time preferred to road tunnels. However, mention must be made of the ancient 'Pertuis du Viso' or 'Buco delle Traversette', a gallery $65 \mathrm{~m}$ long, excavated in the $15^{\text {th }}$ century by the Marquis of Saluzzo, under the high Colle delle Traversette (Cottian Alps), to allow passage of men and mules along the 'salt road' to France (VACCARONE, 1881; CHABRAND, 1910) and to the $64 \mathrm{~m}$ long Urnerloch, built along the San Gottardo road in 17071708 (VIganò, 2007). A true tunnel was that of the Colle di Tenda (Maritime Alps), 3,186 m long, the first Alpine road tunnel and worldwide the longest (CAVINato et alii, 2006). Described in a detailed geological section by BALDACCI \& FRANCHI (1900), the Tenda tunnel was built between 1873 and 1882 , to improve the passage of carriages and stagecoaches along the Italian road from Turin towards the Ligurian coast; soon after it was followed by the longest $(8,099 \mathrm{~m})$ and deepest railway tunnel (1898). There were also projects for other road tunnels, although it was only during the second half of the 20th century, with the revenge of rubber over iron for excavating motorway tunnels of the Grand St Bernard and Mont Blanc across the Pennine and Graian Alps, that many others followed them.

The various studies and plans for the Mont Blanc tunnel are the recurrent theme of this historical contribution. The first idea of linking Savoy with Val d'Aosta with a road tunnel between Chamonix and Courmayeur came from the Genevan Horace B. de Saussure (1740-1796), who had reached the summit of Mont Blanc (1787) after the climbs of Paccard and Balmat (1786), which de Saussure had promoted. His words were prophetic: 'Je vois deux vallées où l'on parle la meme langue, les peuples sont les memes. Un jour viendrà où l'on creusera sous le Mont-Blanc un voie charretière, et ces deux vallées, la vallée de Chamonix et la vallée d'Aoste, seront réunies'. In his 'Voyages dans les Alpes' de Saussure had also seen and described the Val d'Aosta side of Mont Blanc, from the Col de la Seigne to Courmayeur and the Col Ferret, with ascents to the glacier of Miage, Pavillon du Mont Frety and Mont Chétif. After many hopes and disappointments, the Mont Blanc road tunnel was finally built between early 1959 and August $14^{\text {th }}, 1962$, when the last mines broke the diaphragm which separated the tract of tunnel made by the Italians from that of the French. Once internal works had been completed, the tunnel was inaugurated on July $16^{\text {th }}, 1965$, in the presence of Italy's president Giuseppe Saragat and France's Charles De Gaulle.

One hundred and fifty years have passed since the Fréjus tunnel was opened, and more than half a century from that of Mont Blanc: we believe that these epic works should be remembered, together with the names of their promotors, supporters, engineers and geologists. This paper, with emphasis on geology, follows the history of these tunnels in the Western and Central Alps, the various studies and projects, often over-ambitious, their building and basic geological research, and Giordano's applications for San Gottardo and those of Baretti and then of Franchi, Kilian and Jacob for Mont Blanc, until the field work by Paolo Baggio and Giuseppe Mezzacasa during the drilling of the Italian part of the Mont Blanc motorway tunnel. Lastly, research on the French part of the tunnel will be briefly mentioned, from the survey carried out during excavation by the engineer Gudefin of the BRGM, to the outside work done by Georges Vittel when the tunnel was finished, and the petrographic study completed twenty years later by Borghi, Gallo and Porro of an original collection of samples. Transalpine large base tunnels, recently drilled or in progress, are not considered in this historical journey.

Information on historical projects and tunnelling in the Western Alps was mainly provided by Maus (1850), Paleocapa (1850), Conte (1863), Whymper (1871), Bonelli (1880), Schardt (1903a-b), Schmidt (1907), TAJANi (1939), JELMONI (1948), GuichoNNET (1952), RouILLIER (1955), BAGGIO (1958, 1964), JANIN (1962), GuICHONNET \& BERNIERI (1963), LAPORTE (1963), Vitel (1965), Zignoli (1965), Bertoglio \& Chabod (1966), Gudefin \& Vitel (1971), Lesca $(1993,1998)$, Ransom (1999), Duc (2001), Cialdini (2011), CoRsi (2018) and on the websites of the Società Italiana per il Traforo del Monte Bianco (SITMB), the French company (ATMB), the more modern GEIE-MTB, and the Società di Gestione del Tunnel del Gran San Bernardo (SITRASB). We have reported the exact words or have tried to translate faithfully the descriptions and opinions of the main protagonists of this geological and technical history, although at times they may seem repetitive or in contrast with those of others, by inserting where necessary the corresponding modern terms, explanations and a few personal comments.

\section{FROM HORSE-DRAWN CARRIAGES TO THE RAILWAY TUNNELS OF FRÉJUS AND MONT CENIS}

Mont Cenis (Moncenisio, Cenisio in Italian), crossed since time immemorial, had become popular by famous travellers like Montaigne, Alfieri and Chateaubriand, who crossed it in 1803, when work was beginning on the Napoleonic road. It is difficult to imagine, these days, how the Alps were passed before the tunnels were built. In the mid-19 $19^{\text {th }}$ century, the journey from Paris to Turin required a minimum of thirty-five hours and involved some tracts by train, some by boat, and yet others in carriages (CIALDINI, 2011). To pass Mont Cenis, the train arrived only as far as St Jeanne-de-Maurienne; its passengers then continued in stagecoaches which, if everything went well, reached Susa in six hours, and from there travellers took the railway to Turin. The Compagnia Vittorio Emanuele, which managed 
the Mont Cenis service, had a fleet of 280 carriages, sledges and trucks for goods and passengers: despite the high prices and the difficulties involved in changing carriages, 40,000 travellers and 22,000 tons of goods crossed the pass every year.

\section{Henry Maus' plan}

It was Giuseppe Francesco Medail (1784-1844), a customs commissioner from Bardonèche (modern Bardonecchia), who first launched the idea of a railway tunnel under Mont Fréjus, the ideal solution to improve the otherwise difficult links between Piedmont and Savoy. Following information from CIALDINI (2011), in 1839 and 1840 Medail sent two reports proposing the plan to the Sardinian government, but did not receive any answers: railways were not yet part of the government's programmes, although they were mentioned in the Second Congress of Italian Scientists in Turin (1840). In 1841 Medail did not give up hope, and sent a third report to King Carlo Alberto, which began with these provocative words (translation): 'All illuminated minds know that easy and ready ways of communication are the essential basis for the prosperity of nations.' His proposal was corroborated with an accurate topographic map of the area, showing the route of the tunnel between Bardonèche and Modane (the proposal later adopted by Sommeiller), executed on Medail's orders by the officer of Civil Engineering Ignazio Porro. Also in this case, nothing was done. Three years later Medail died while travelling from Lyon to Turin, without ever succeeding in being received by the King and discussing the project with him.

Meanwhile, in 1841 a preliminary project for the Fréjus tunnel had been proposed by the Belgian engineer Henry J.M. Maus (1808-1893), a railway expert, on behalf of Luigi des Ambrois de Nevâche (1807-1874) from Val Susa, at that time general superintendent of Nice. In 1845, nominated minister by King Carlo Alberto, des Ambrois commissioned Maus to write a 'preparatory study' to assess the possibility and conditions of digging the Fréjus tunnel, with the geological collaboration of Angelo Sismonda (1807-1878), a famous professor of mineralogy at the University of Turin. Confirmed by French colleagues, including Elie de Beamont, Lory and Mortillet, the study described the type and quality of the rocks along the proposed tunnel and the possibility of flooding, sometimes considerable, but excluded serious hindrances as regarded excavations: 'Sismonda's studies had made the mountain transparent' was the brief comment appearing in a newspaper of the times (CIALDINI, 2011).

Maus's project (February $8^{\text {th }}, 1849$ ) involved a tunnel between Modane and Bardonecchia, 12,290 metres long, with a southern entrance at 1,364 $\mathrm{m}$ a.s.l., under Moncenisio (in fact, Mt Fréjus) without intermediate digging. An excavating machine, called a 'mountain slicer', planned and tested by Maus himself, would have allowed work to be carried out in less than ten years: the machine was composed of a truck with a frontal system of percussion excavators activated by cables which transmitted energy from a hydraulic engine installed at the mouth of the tunnel; as excavation advanced, these trolleys had to become longer and longer, and they would also pose problems of technical management (MAUS, $1850 \mathrm{a}-\mathrm{b}-\mathrm{c}$; CIALDINI, 2011).
In July 1849 Maus's project was examined and approved unanimously by a commission composed of Giovanni Galvagno, minister for public works (chairman), Pietro Paleocapa, Ignazio Giulio (senators of the Realm), Carbonazzi, Melano and Barbarava (inspectors of Civil Engineering), Menabrea (foreign minister), Cavalli (artillery major) and Sismonda himself. The minutes of the commission appear in 'Report by Cavaliere Enrico Maus and report by the inspector Cavalier Pietro Paleocapa' (MAUs, $1850 \mathrm{a}-\mathrm{b})$. The insurrectional actions of 1848 put an end to the project, including Maus's intricate excavation system.

The Giovi railway tunnel (1848-1853) had been an important experience, from the viewpoint of assessing the technical problems of excavation effected entirely by hand, with the support of Pietro Paleocapa to reach beyond the Appennine watershed, along the Turin-Genoa line. The tunnel was 3,265 m long - very long for such an enterprise - but nothing when compared with the unknown problems of the much longer Fréjus tunnel.

\section{The FréJus Railway Tunnel}

About ten years later, the Fréjus Railway Tunnel project was taken up again and developed by Germain Sommeiller (1815-1871), supported and presented in Parliament by Luigi F. Menabrea (1809-1896) and Pietro Paleocapa (1788-1869), the new minister for public works, first with d'Azeglio and then with Cavour. On August 15th 1857 , the Chambers approved the building of the BussolenoModane railway with its tunnel. Speaking in Parliament, Cavour pronounced that he was in favour of the project: 'Lastly, I declare openly, I have faith in the engineers who proposed this enterprise, and I do this because I know, as minister and as a private citizen, their capacity and honesty, and I will say more, their modesty; because I know that these engineers, throughout their long and luminous careers, have always maintained much more than they had promised'.

Technical management of the works was assigned to Sommeiller, Grattoni and Grandis, young engineers of the Royal Civil Engineering: after their degrees from the University of Turin, they had been sent to Belgium and England to specialise in the railway sector, on the suggestion of Carlo Ignazio Giulio (1803-1859), trusted councillor of King Carlo Alberto. The Fréjus tunnel, 12,234 m long, was built between 1857 and 1870, twelve years less than the original forecast for excavations by hand, based on the example of the Giovi case, thanks to the efficiency of a new type of pneumatic drill: conceived by the Genevan physicist Colladon and the Milanese engineer Piatti, it had been planned and perfected by Sommeiller and tested by a governmental technical commission composed of Luigi Des Ambrois (chairman), Carlo Ignazio Giulio, Federico Menabrea, Dionigi Ruva and Quintino Sella (PALEOCAPA, 1850; Sommeiller, 1857; Piatti, 1858; Conte, 1863; Grandis et alii, 1863; Treves, 1864). The first compressed-air drilling machinery reached the front of the excavation on January $12^{\text {th }}, 1861$, but only on January $25^{\text {th }}$, 1863 it started operating in the Bardonecchia side, after technical innovations developed by Sommeiller and his engineers (Conte, 1863; Lesca, 1993, 1998; Cialdini, 2011; Corsi, 2018). Sommeiller periodically reported to Parliament and the city council of Turin regarding the ongoing escavations and, rightly, did not forget to praise the workmen, who were 'full of courage and energy, and untiring' (SOMMEILLER et 
alii, 1863). The last rocky diaphragm was perforated by the drilling machine by Christmas 1870 and excavations were finished the day after (Giordano's eyewitness account), while the inauguration took place on September $17^{\text {th }}, 1871$, in the presence of King Vittorio Emanuele II and with a celebrative speech by Quintino Sella, rightly praising the ability of the Piedmont engineers (Bignami, 1861; Palmero, 1872; Cialdini, 2011; Dal Piaz, 2013).

The Fréjus railway tunnel was a highly innovative excavation, using or developing during the work many new technologies, such as topographic surveys, the electric telegraph, hydraulic power, compressed air, metallurgy and the vulcanisation of rubber, integrated harmonically to achieve a project which many believed was utopistic and destined to fail (LEsCA, 1993).

The tunnelling work also attracted an unexpected visit from Edward Whimper, an event little known in Italy. A young English designer-engraver, Whimper had been sent to the Dauphinois Alps in 1860 to produce sketches of great Alpine peaks for editorial purposes. Before beginning the epic battle for the conquest of the Matterhorn (Monte Cervino), in 1861 Whimper had seen the works ongoing in the Mont Cenis (Fréjus) tunnel from the French side, and had made many drawings which appear in his book 'Scrambles amongst the Alps', including his famous picture of the drilling machine and the workmen (Fig. 1a), which was reproduced in many articles without mention of the artist's name.

The drilled rocks were described in a note by GIORDANO (1871), proceeding from the Italian side towards the French exit (further information in ELIE DE BEAUMONT, 1871a, b): i) beige limestone, schistose, partly micaceous, with veins and geodes of white quartz, in layers dipping $20^{\circ}-30^{\circ}$ north-west: length about $9,394 \mathrm{~m}$; ii) alternations of crystalline limestone, more or less dolomitic, anhydrite, carnieule (vacuolar dolomite), chloritic and serpentinitic schists, like the preceding ones: about $356 \mathrm{~m}$; iii) compact quartzite, with some anhydritic nodules, in almost vertical

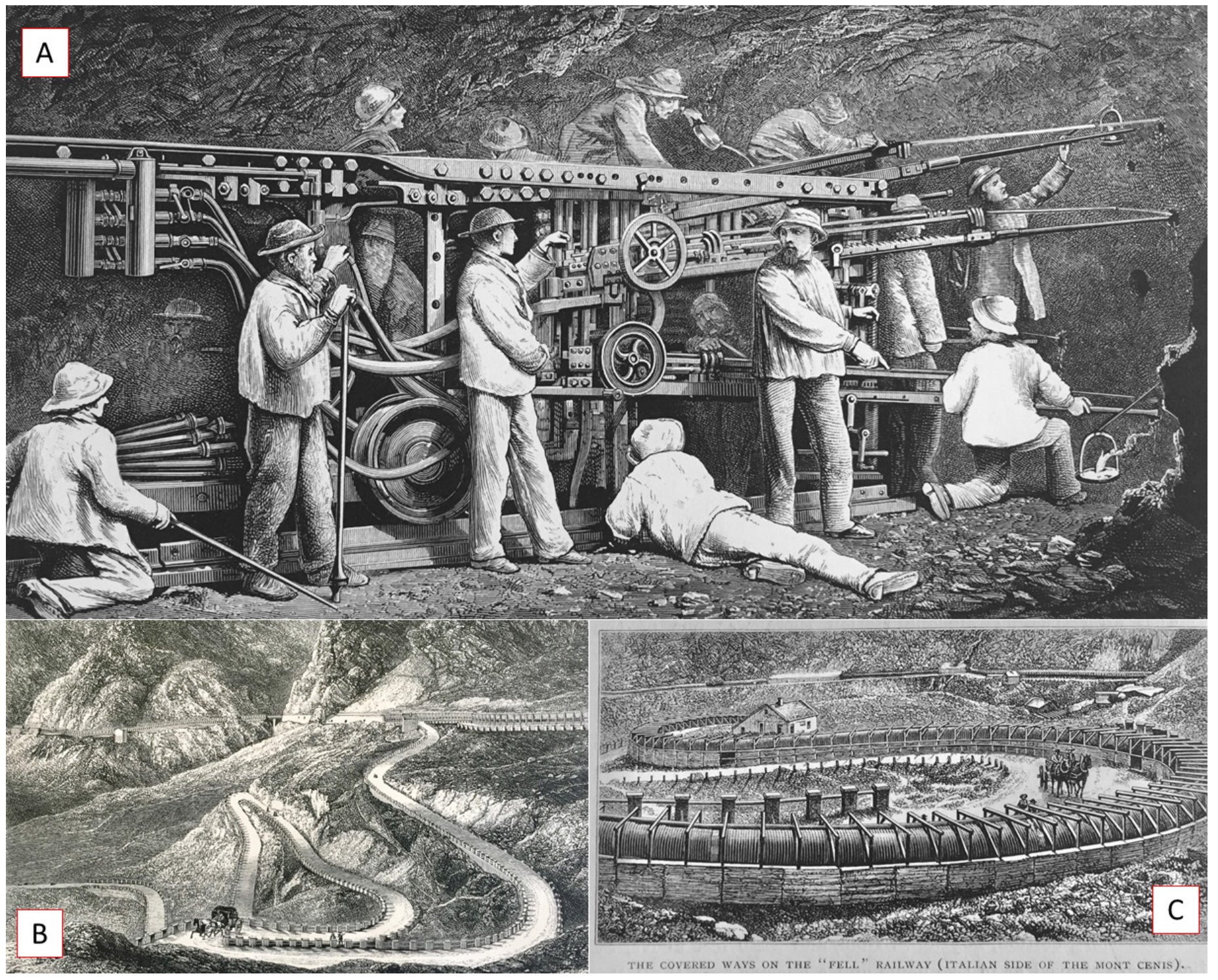

Fig. 1 - Sketches by Edward Whymper from his visit to the "Grand Tunnel" in 1861 (Scrambles amongst the Alps, 1871): (A) Drilling machine and the workmen in Mont Cenis tunnel, French side; (B) Mont Cenis Napoleonic road and Fell's railway; (C) covered ways on the Fell's railway, Italian side. 
banks: $388 \mathrm{~m}$; iv) sandstone and black schists, with traces of the 'anthracitic terrain' of Savoy, in straightened and contorted banks: 2,096 m. Water seepage was very seldom found, and rock temperatures were lower than foreseen. Between 1861 and 1870, Sismonda carefully prepared a lithological collection of the Fréjus tunnel, in several series, to be given to the leading naturalistic museums in Europe. One of them is now in the Museo Regionale di Scienze Naturali (MRSN) of Turin and contains more than 570 samples.

\section{Fell's Railway Plan for the Mont Cenis Pass}

In 1866, when the Fréjus tunnel was still under construction, the English engineer John Barraclaugh Fell, financed by a group of British entrepreneurs, built a railway connection, $78 \mathrm{~km}$ long, between Susa (503 m) and Saint Michel-de-Maurienne $(698 \mathrm{~m})$ through the Mont Cenis $(2,083 \mathrm{~m}$; in this case, the true pass), following the Napoleonic road (Fig. 1A and 1C) (WhYMPER, 1871; RANSOM, 1999; CiAlDINI, 2011). In the steepest tracts and narrowest curves, the railway had a third central rail, on which two supplementary engines acted, both in traction and braking (Fell's system). The convoy was composed of a steam locomotive, three passenger carriages (with a total of 36 seats) and three freight wagons. The journey lasted five hours, at a medium speed of $15 \mathrm{~km} / \mathrm{h}$.

The Fell Mont Cenis railway was an ephemeral project, although during its four years of work (1868-1871) it managed to transport about 100,000 travellers, including the Indian Mail, but was obliged to close down when the very faster and capable Fréjus railway tunnel was opened; the latter is still used for transfrontier and international links while awaiting the completion of the Euro-Alpine Turin-Lyon base tunnel. The rails of the Fell railway were dismantled and re-used in Brazil for the 'Estrada del Ferro Cantagalo' (CIALdinI, 2011).

\section{FURTHER DISCUSSIONS ON THE MONT BLANC WHILE DRILLING OF A ROAD TUNNEL BETWEEN AOSTA AND VALAIS IS ABANDONED}

De Saussure's hopes of drilling a tunnel under Mont Blanc had a first real rebound in the early $19^{\text {th }}$ century when, after Napoleon's defeat, the Congress of Vienna (1814) had re-assigned Piedmont and Savoy to the Reign of Sardinia, also adding Liguria. Once back on the throne, Vittorio Emanuele I (1759-1824) asked the cities of the Sardinian States to inform him of their needs for development: Courmayeur expressed its wish for a tunnel under Mont Blanc, to link it with Chamonix, but this request was not followed by any project.

The idea was taken up again by the lawyer Laurent Martinet (1799-1858) who, in the Feuille d'Annonces of Aosta in 1844, had reproposed a tunnel under Mont Blanc from les Bossons, near Chamonix, to Entrèves, along the track which, over a century later, was approximately followed by the motorway tunnel.

After the second war of independence, the Treaty of Turin (1860) had accepted the passage of Nice and Savoy from the Reign of Sardinia to France, conferring its political character and accentuating the isolation of Courmayeur and Chamonix. After the completion of the
Turin-Genoa railway, in 1858 the engineer Joseph Bonelli (1880) had presented the government with a project for another railway line from Turin to Geneva, with a tunnel under Mont Blanc. Two tracks were proposed: one from Prè-St-Didier to Taconnaz, south-west of Chamonix (18.5 $\mathrm{km}$ long), the other from Courmayeur to Taconnaz (16 $\mathrm{km}$ ), both believed to be possible and technically simple by Godin de Lépinay, engineer of the Ponts et Chaussées (Bonelli, 1880; Rouiller, 1955; Zignoli, 1965). As regards definite developments, no geological studies are known.

Instead, this time a road was proposed between the valley of Grand St Bernard, north of Aosta, and the valley of Entremont in Valais, favoured by the Canon Georges Carrel with the support of the deputy Laurent Martinet and an agreement with the Helvetic Confederation (1851). The project had been presented in 1852 by Luigi Guallini, head engineer of public works of the Reign of Sardinia. He had proposed a tunnel under the Col de Menouve (modern Menovy, 2,765 $\mathrm{m}$ a.s.l.) between the Grand St Bernard pass and the massif of Mont Velan, about 2,330 m long, $6 \mathrm{~m}$ wide, and with a southern entrance at 2,350 m. In 1856 the Senate and Chamber of Deputies had approved the project, and a decree by Vittorio Emanuele II (February 13 $3^{\text {th }}, 1856$ ) authorised the extraordinary expense of 185,000 lire. This was true folly: the works, assigned to the company Sogno and Serra of Aosta, immediately began work on the two sides, but stopped the following year, due to excessive altitude, serious environmental difficulties, and insufficient funds. The Menouve valley was definitively abandoned, maintaining its natural beauty.

According to the modern topographic and geological maps of the Regione Autonoma Valle d'Aosta, the southern entry would have been located between the Tsa de Menovy $(2,240 \mathrm{~m})$ and Tsa Nouva $(2,405 \mathrm{~m})$ pastures. Starting from the southern entrance, it would have had to cross obliquely the following tectonic units of the middle-Penninic Grand St Bernard nappe system: i) the polymetamorphic basement of the Siviez-Mischabel unit; ii) the silico-clastic postVariscan rocks of the Gran Testa; iii) the polymetamorphic basement of the Ruitor unit (for details, see BIGI et alii, 1990, Gouffon, 1993, and De Giusti et alii, 2004).

\section{ADVANCES IN GEOLOGICAL RESEARCH AND MAPPING IN THE WESTERN ALPS}

Now let us see the state of geological knowledge on the Western Alps. By the mid-19 ${ }^{\text {th }}$ century, geological exploration of the Western Alps had made considerable progress, as shown by SismondA's studies $(1839,1845)$, the 'Carte géologique de la France', 1:500,000, of DuFrÉnoI \& Elie de Beaumont (1840-1841), the 'Carte géologique du Dauphiné (Isère, Drôme, Hautes-Alpes)' at 1:250,000 of LoRy $(1857,1858,1860)$, the 'Carta geologica della Savoia, Piemonte e Liguria' at 1:500,000 of SISMONDA (1862-66), the 'Karte der Penninischen Alpen' at 1:200,000 of GerLach (1869), with illustrative notes and, in particular, the handdrawn 'Carta geologica delle Alpi Piemontesi' by BARETTI et alii (1860-1879), also called Gastaldi's 'Gran Carta', composed of 29 sheets, scale 1:50,000 (CAmpanino \& Polino, 2002; DaL PIAZ, 2013).

The fan-like shape of the Mont Blanc granite had been rightly envisaged by Forbes (1843) and STUDER (1851) (Fig. 2A and $2 \mathrm{~B}$ ). Of special interest as regards the Mont 


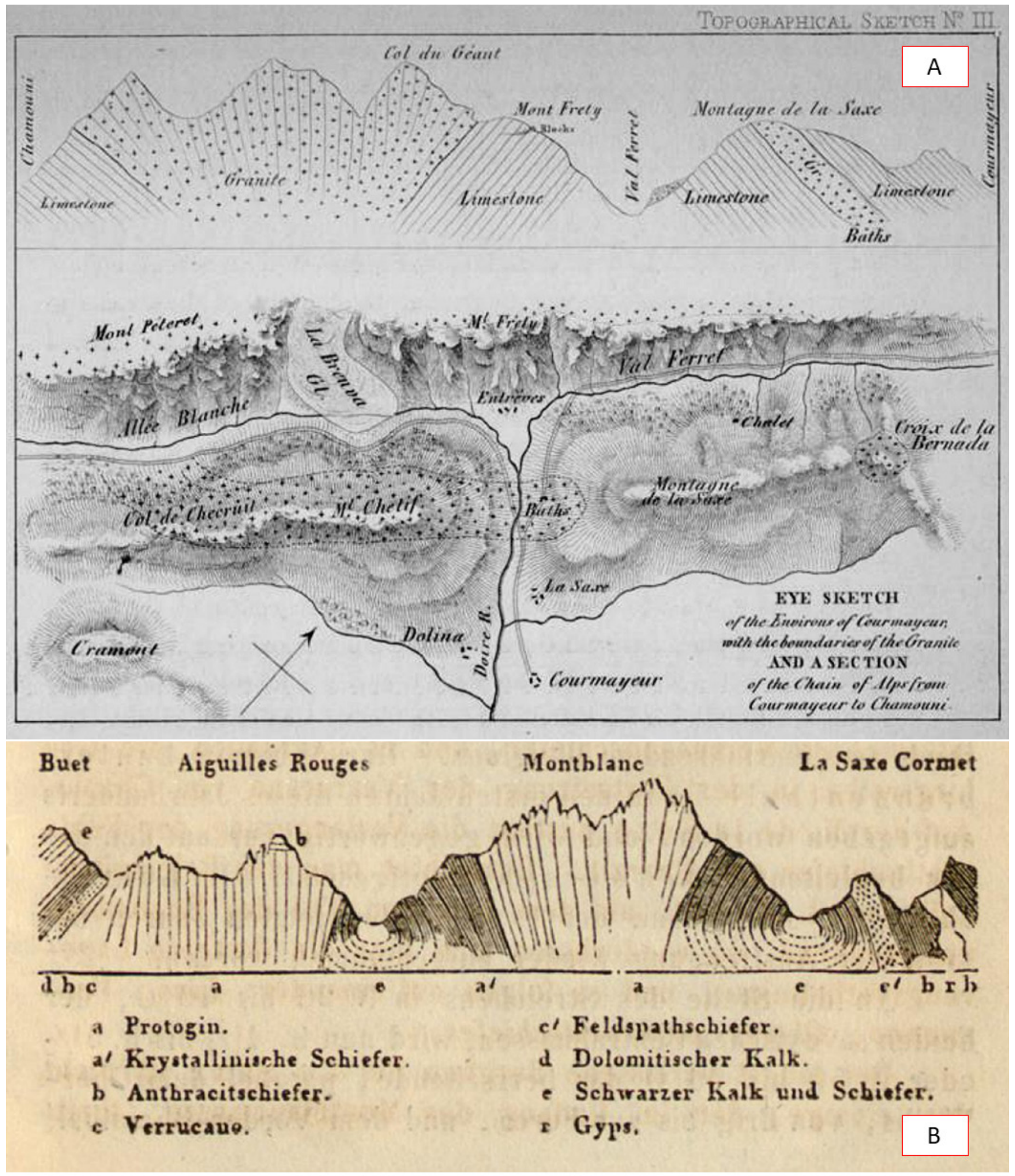

Fig. 2 - Fan-like structure of the Mont Blanc massif drawn by (A) the Scottish James D. Forbes (1843) and (B) the Swiss Bernard STuder (1851).

Blanc massif and the possible plan for a tunnel could have been clearly shown by the mapping and basic research of Alfonse Favre (1815-1890), professor of geology and paleontology at the Academy of Geneva, by Charles Lory (1823-1889), professor of natural history at Grenoble, and by Domenico Zaccagna (1850-1940), with a degree in 
engineering from Turin, upgraded at the Ecole des Mines in Paris, and member of the Royal Italian Geological Survey.

In his 'Carte géologique des parties de la Savoie, du Piémont et de la Suisse, voisines du Mont-Blanc', scale 1:130,000 (1862) and his monumental illustrative notes (1867 a-b) Alphonse Favre had described the nucleus of older granite (named "la protogine" by JURINE, 1806) and the surrounding 'stratified units' with observations, drawings and accurate measurements, confirming the fan-like shape of the massif. Favre believed in the normal stratigraphic succession of rocks outcropping in the region, structured in a series of flanking synclinal and anticlinal folds, with cylindrical geometry and partly eroded or buried: the syncline core consisted of the Jurassic terrains (mainly Cretaceous) of Chamonix and Val Veny, bordered by thin Triassic dolostones, whereas the schists and the nucleus of gneissic granitoid (protogine) of Mont Blanc were believed to be older than the surrounding schists. Favre had also mapped and reconstructed in sections the granite and schistose porphyries of the Mont Chetif-Montagne de la Saxe ridge (anticlinal), near Courmayeur, and their partial overturning on the black limestones and clayey schists 'evidemment triasiques' of Val Ferret (syncline), constituting 'la superposition monstrueuse des roches primitives sur les secondaires' observed by de Saussure. To the south, the Mesozoic terrains of the Crammont sink under the Carboniferous terrains of the Thuile valley in overturned succession.

Graduated in 1846, Charles Lory had begun to study the Briançonnais and the problem of Carboniferous sandstones in 1857. The results of his research are illustrated in the 'Description géologique du Dauphiné, notes to the above-mentioned map (LoRY, 1858, 1960). This was followed by the 'Carte géologique de la Maurienne et de la Tarentaise (Savoie)' and completed with the 'Carte géologique du département de la Savoie', scale 1:150,000 (LoRY et alii, 1869). In the section for the high Valle d'Aosta, between the massif of Mont Blanc and the village of $\mathrm{La}$ Salle, the map shows the following succession: i) schistose Jurassic sediments between the basement (protogine and ancient schists) of Mont Blanc and the chloritic-micaceousamphibolic gneiss of Mont Chetif; ii) quartzite, dolostone, evaporite, chalk, carnieule and prevailing Triassic schistes lustrés, extending from the southern flank of Mont Chetif to the valley of La Thuile, where they sink below the Carboniferous schists and conglomerates (section later upgraded by FranchI, 1907, and FRANCHI et alii, 1908). Lory's main innovation was to report the presence of large faults, both between the crystalline massifs of Mont Blanc and Brévent (Aiguilles Rouges), causing deepening of the Liassic beds in the Chamonix valley, and those in the Valle d'Aosta: the former among the Jurassic schists of Entreves and the overlying gneiss of Mont Chetif, the latter between the Triassic successions of CourmayeurMorgex and the overlying Carboniferous schists, no longer in the stratigraphic relationship maintained by Favre, but in tectonic contact. It should be noted that these were medium-angle faults 'along the strata', which today we call frontal ramps or thrusts and which they in fact are, since the former is the tectonic contact between the Helvetic and Ultrahelvetic units and the latter the Penninic frontal thrust.

To complete the project for the new Geological Map of Italy, the Geological Committee had engaged Domenico
Zaccagna to carry out the mapping of the Maritime Alps (1883), then of the Cottian Alps (1884-85) and, lastly, together with his colleague Ettore Mattirolo, of the Mont Blanc massif (1886), with extensions to Savoy and the Nice region (1887), an immense field work (BARALE et alii, 2018). These researches had been described in the memoir 'Sulla Geologia delle Alpi occidentali' (ZaccaGna, 1888), and related 'Carta Geologica delle Alpi occidentali', scale 1:1,000,000, and several sections at 1:100,000, including those across the Chamonix valley, Mont Blanc and the Valle d'Aosta, extending as far as Valgrisanche (not suitable for reproduction). Among the most important new results was the identification in the Maritime and Cottian Alps of extensive bodies of 'anagenite' (conglomerate) and schistose gneissic porphyroid, correctly referred to the Permian, and their presence also at the Mont ChetifMontagne de la Saxe-Testa Bernarda ridge, which Favre and Gherlach had attributed to the archean basement. The section shows the Permian succession which dips below the Triassic dolomitic limestone of $M$. Brisè and the Tête de la Tronche (Val Sapin), followed above by the calc-schists of the Crammont, attributed to the Triassic, in accord with Lory. However, Zaccagna did not believe in the existence of Lory's faults, but returned to the model of a normal stratigraphic sequence within a large recumbent synform, with an axial plane dipping SE as far as the Carboniferous successions. Zaccagna was also in favour of the traditional older age of the greenstone zone of GASTALDI (1872), including the calc-schists with associated greenstones (metamorphic ophiolite) of the Graian Alps; these were the successions which, shortly after, Franchi had rightly attributed to the Mesozoic in 1898, providing the regional stratigraphic basis for the nappe-bearing structure of the whole Western Alps drawn by Emile Argand (details in DAL Piaz \& Dal Piaz, 1984 and Masson, 1983).

We have no evidence of a direct involment of Favre, Lory and Zaccagna in the possible applications of their field research to tunnel projects like those of Mont Blanc. This plan was taken up again by Martino BARETTI (1881) and completed with accurate geological, structural and technical data and expected features regarding drilling, rock stability and hydrology, as inferred from a detailed surface geological survey.

\section{THE SAN GOTTARDO RAILWAY TUNNEL}

In 1865 Stefano Jacini (1826-1891), Italy's new minister for public works, had set up a commission for a comparative geological study of the three large railway tunnels, then planned across the Italo-Swiss Alps: San Gottardo, Lucomagno and Spluga, with many variations (Dal Piaz \& Argentieri, 2019). The committee, composed of Angelo Sismonda (chairman), Antonio Stoppani and Felice Giordano (referent) had carried out - within the short space of time conceded to them - a geological study of the topographic tracks put forward by the Promoting Committee and the Province of Milan. They stated, with pleasure, the following comments: 'in our country, it is very rare that, before beginning a colossal work of public construction, the work was not only examined from the political and economic aspects, but also from the scientific one, and the public has been informed of the results obtained from them' (SISMONDA et alii, 1865). The commission 
confirmed the feasibility of three tunnels and their substantial equivalence from the geological and technical viewpoints, and requested the political and economic powers to make a definitive choice. For substantial political and commercial reasons, the choice fell in favour of the San Gottardo railway tunnel across the Lepontine Alps. In 1869 - the same year as the opening of the Suez Canal - Switzerland, Italy and Germany decided to begin work, estimated to last for nine years, and signed an agreement (Bern Convention) to finance the enterprise: Italy would contribute with 45 million Swiss francs, and Germany and Switzerland with 20 million each.

\section{The study by Felice Giordano}

Geological study of the route was carried out in summer 1871 by Felice Giordano (1825-1892), inspector of the Royal Corps of Mines, with the collaboration of the young engineers A. Alessandri and F. Momo, with assistance from prof. Bartolomeo Gastaldi (1818-1879) for the petrographic analysis of many samples. His report had been printed in 1872 and then published in the 'Memorie descrittive della Carta geologica d'Italia' (1873) with the title (translated) 'Geological examination of the Alpine Chain of San Gottardo which must be crossed by the great tunnel of the Italo-Swiss railway' (DAL PIAZ, 1996; Console, 2016; Dal Piaz \& Argentieri, 2019). Dated 1871, it contained a geological map of the San Gottardo (scale $1: 50,000$, surveyed at about $1: 15,000)$ the sections and planimetry of two straight tracks, slightly divergent, from Goeschenen to Airolo (C-D on the geological map), which was the preferred one, and from Goeschenen to Madrano (C-E), respectively 15.07 and $15.75 \mathrm{~km}$ long. The memoir includes a detailed description of the rocks expected to be found along the tunnel, in succession from south to north (nature, age, attitude, thickness, hardness or resistance to drilling, stability and construction materials), as described below.

\section{The rocks of the Tunnel}

Referring to the geological map and the sections (Fig. 3A and 3B) of the route between Airolo (elevation $1,155 \mathrm{~m}$ a.s.l.) and Goeschenen $(1,110 \mathrm{~m})$, we summarise here Chapter III of the monograph entitled 'Descrizione delle rocce da attraversarsi colla galleria'. The entrance near Airolo avoided the permeable belt of limestone, dolomitic rocks and evaporitic beds exposed south of the village, which was crossed by the Madrano-Geschenen variant, and to penetrate directly the crystalline basement of the 'Giogaja del Gottardo', which extended to the Andermatt lowland. Starting from Airolo, these are the lithotypes and structural attitudes foreseen in eight separate sectors of the tunnel, which trended N04W:

(1) Sector $0 \rightarrow 620 \mathrm{~m}$ : micaschist passing to micaceous gneiss, with abundant dark red garnet and quartz veins, schistosity and bedding dipping NW by $40^{\circ}-50^{\circ}$.

(2) Sector $620 \rightarrow 3,530 \mathrm{~m}$ (segment length: $2910 \mathrm{~m}$ ), under the Alpe di Seipscius: crystalline schists rich in amphibole with metric banks of blackish amphibolite; attitude similar to the preceding one.

(3) Sector 3,530 $\rightarrow 5,210 \mathrm{~m}(1,680 \mathrm{~m})$, under the lake of Sella: foliated gneiss with nodules of white feldspar
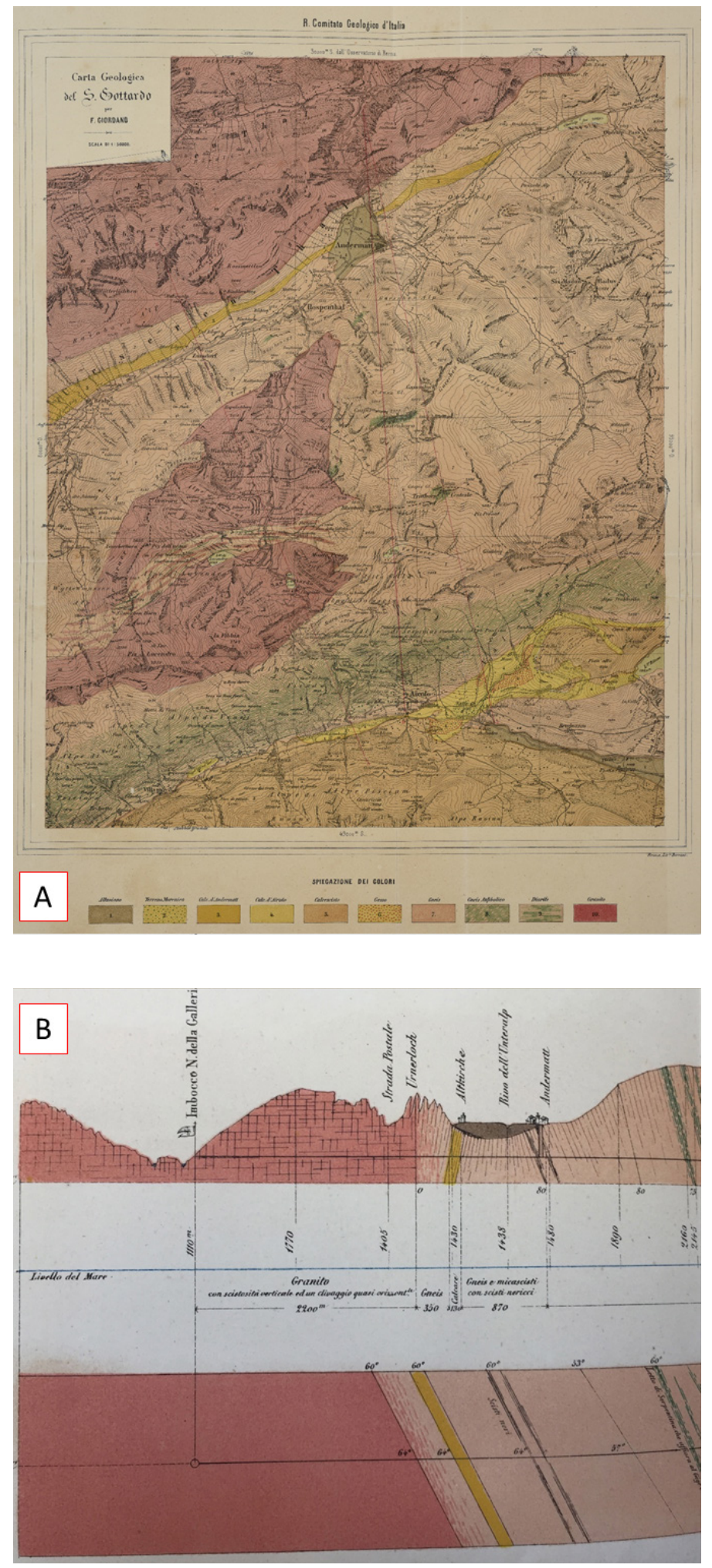

Fig. 3 - Geological study for the San Gottardo tunnel carried out by Giordano in summer 1871 and alleged to the memoir 'Esame geologico della catena alpina del San Gottardo che deve essere attraversata dalla grande galleria della ferrovia italo-elvetica' (GIORDANo, 1873): (A) geological map at 1:50,000 scale of the Gottardo massif; (B) details of section and planimetry at tunnel level of the northern part of the Airolo- Goeschenen profile, showing from the right the Gottardo paraschist complex with intercalations of serpentinite and black schists, the Andermatt alluvial plain with the crystalline limestone hidden below Altkirche, the vertical contact near Urnerloch between gneissic schists and granite of the Aar massif (sectors 5-6-7). 
(modern gneissic granitoids), similar direction, with progressively accentuated dip.

(4) Sector $5,210 \rightarrow 11,520 \mathrm{~m}(6,310 \mathrm{~m})$ : in the first $1,685 \mathrm{~m}$, under the Guspis valley, predicted alternations of micaschist and finely schistose gneiss with intercalations of green rocks (amphibolite and diorite) outcropping at Tritthorn and mainly at the Kastenhorn ridge $(2,977 \mathrm{~m})$; this is the central tract of the fan-like structure, dipping first NW by $60^{\circ}$ and then SE by $75^{\circ}$. The schists and gneiss north of Kastenhorn (the following 4,625 m) are probably free of other large intercalations of greenstones, except for the possibility of finding a talc-serpentinitic mass at about 9,800 $\mathrm{m}$ from the Airolo entrance, inferred from those rocks outcropping both west (talcschists, at the village of Gigè, above Hospenthal) and east (green serpentinite, Unteralp valley) of the route; crystalline schists continued to the Andermatt plain, without substantial variations and always with very steep schistosity to the south-east.

(5) Sector $11,520 \rightarrow 12,390(870 \mathrm{~m})$, subsoil of the alluvial plain of Andermatt, inferred from surrounding areas (Fig. 3B): ash-gray micaceous schists, finely zoned and passing to gneiss, alternating with banks of blackish coal schists, possibly of Carboniferous age; schistosity first dipping SE by $80^{\circ}$, then vertical, and then NW by $80^{\circ}$.

(6) Sector $12,390 \rightarrow 12,520(130 \mathrm{~m})$ : hectometric bank of lastroid crystalline limestone (cipollino), from saccaroid to very micaceous, embedded in gneissic schists, partly exposed under the old church (Altkirche) north of Andermatt; trending $\mathrm{N} 60^{\circ}$, subvertical to strongly dipping NW, thickness about $130 \mathrm{~m}$.

(7) Sector $12,520 \rightarrow 12,870(350 \mathrm{~m})$ : towards the Urnerloch road tunnel, the usual gneiss, more or less schistose, is followed in vertical contact by the granite of the northern chain (Fig. 3B). The Urnerloch, the oldest gallery for Swiss road traffic, $64 \mathrm{~m}$ long, had been drilled with black powder explosive by the Ticinese engineer Pietro Morettini in 1707-1708 to allow passage for people and mules (Viganò, 2007), later several times amplified, starting with the building of the San Gottardo road (1830).

(8) Sector $12,870 \rightarrow 15,070(2,200 \mathrm{~m})$, as far as the northern entrance of Goeschenen: more or less homogeneous granite with feldspar crystals; pervasive vertical joints in the usual regional trend $\mathrm{N} 60^{\circ} \mathrm{E}$ and frequent subhorizontal cleavages.

\section{The schistose granite west of the road and its origin}

The monograph includes a third profile traced across the western sector of the map, from Bedrina to Zumpdorf (A-B), partly along the San Gottardo road from Airolo to Hospenthal (Fig. 3B), without proposing it as a suitable railway variant. One tract was to be chosen for the Gotthard highway tunnel, 16,942 m long, inaugurated in 1980 after ten years of work (structural setting and brittle deformations reported by ZaNGERL et alii, 2006). Following Giordano, the area is distinguished by two large granitic bodies, absent in the other two tracks. The southern body (Fibbia granite) forms the true San Gottardo mountain group, being about $2.8 \mathrm{~km}$ wide and, west of the map, reappearing in the Monte Rotondo massif. The northern body (Gamsboden granite), more than $3 \mathrm{~km}$ wide, forms the peaks of Furkaegg, Schwarzloch and Winterhorn, and terminates with a very clear-cut eastern boundary which crosses the valley, about one kilometre west of the
Airolo-Goeschenen railway tunnel. The granitic bodies are both disseminated with feldspar crystals and, together with the surrounding schists, show evident schistosity trending $\mathrm{N}^{\circ} 0^{\circ}$, with high-angle dipping towards $\mathrm{NW}$ in the southern sector and towards SE in the northern one, confirming the great fan-shaped structure described in the preceding profiles. The granite bodies are separated by an 'intermediate schistose zone', 500-600 m wide, 'where every so often granite, gneiss and micaschists are arranged in parallel bands, several times alternating among themselves with such structural grades that they would appear to indicate their identical origin'. One could thus deduce that they were not igneous bodies intruding between schists and gneiss, but simply schists transformed into granite due to more intensive alteration (anticipating the metasomatic views of Baggio and Malaroda on the Mont Blanc granite). Instead, at other points, contacts appear completely 'irregular and bizarre', indicating that the granite was 'an originally mellow rock'. This now wraps large sections of schists, or occurs as dykes and veins of varying sizes which, starting from the main mass, lie between those gneiss and schists. Very fine examples of these injections are reported by Giordano slightly south of the San Gottardo Hospice and in many other localities of these granitic bodies.

Referring to modern geology (e.g., BIGI et alii, 1990; Steck et alii, 1999; OBERHänsli et alii, 2004; GlotzBach et alii, 2008, 2011; GunTLI et alii, 2016), Giordano's geological map, from south to north, consists of the following firstrank units: 1) North-Penninic Mesozoic calc-schist (the 'calceschist' of Giordano), front part, right side of the Val Bedretto, south of the Airolo entrance; 2) the Ultra-Helvetic massif of Gottardo, from Airolo to Urnerloch, slightly north of Andermatt; 3) the Helvetic Aar Massif, with the foliated granite of its internal edge, from Urnerloch to Goeschenen.

\section{Technical geology}

These applications of 'practical geology' are described in detail in the second part of Giordano's monograph.

Water seepage - Tunnelling may encounter problems of water flowing only in the tract in which the tunnel passes $300 \mathrm{~m}$ under the low plain of Andermatt, an ancient lake, now filled in, due to the Altkirche limestone which may allow water from alluvial deposits to infiltrate the tunnel. In this view, the possibility of drilling a vertical well about $310 \mathrm{~m}$ deep was evaluated to allow the water to drain away, which would improve aeration and provide an addition excavation front (although this proposal was not accepted).

Temperature - The topographic and altimetric conditions of the tunnel and the Gottardo chain above are almost equal to those of the Moncenisio (Fréjus), and their crystalline rocks, although differing, should have similar thermal conductivity. It was thus possible to state that, at the centre of the tunnel, the temperature of the rock would not exceed $27-28^{\circ} \mathrm{C}$ (underestimated), like the Moncenisio, and then would gradually decrease towards the entrances.

Rock hardness and solidity - The crystalline rocks of the Gottardo were predicted to be generally slightly harder and more resistent than the crystalline limestone of the Moncenisio. The granite and most of the foliated gneiss 
of the northern side of the Gottardo are the best rocks for drilling, being harder than the amphibolic schists of the southern side, with possible peaks for intercalations of massive greenstone, especially that of the Kastenhorn, although not reaching the extreme hardness of the Cenisio quartzite. Although the absence of quantitative data on the 'pratical experiments' (technical tests) carried out at the Mont Cenis with mechanical diggers (thus Giordano complained) it was probable that the mean daily advance of the Gottardo tunnel and the problems expected to arise during works of such dimensions, were similar to those encountered during the excavation of the Mont Cenis tunnel below the Cottian Alps, apart from its greater length. 'On the other hand, the precious experience already acquired by the Italian engineers' (Giordano implicitly believed that overseeing the works would be assigned to them), 'the considerable hydraulic power available near the entrances and, lastly, an excellent system of high-power drills, will overcome any difficulties, as the work will be put in capable hands and we hope that the work may be achieved in that limited number of years foreseen by the same engineers'.

Giordano believed that the crystalline rock of the tunnel was generally so solid that it did not require masonry cladding: this had been the case of the Urnerloch tunnel in granite and also that of the Madrano gneiss and micaschists, both extremely solid for many years. Possible exceptions might come from the southern sector, due to differing perforability between micaceous schists and interbedded banks of harder amphibolitic rocks, as well as the Andermatt limestone. In any case, as this was to be a railway tunnel, it would be prudent to cover at least the vault, work which would involve several hundred thousand cubic metres of solid walling, also necessary outside the tunnel itself.

Construction materials - Especially in the northern section, the surroundings could supply micaschist and granite, as excellent building and covering stone. Lowquality calc was available from the carbonatic rocks of Airolo and Andermatt, but hydraulic calc would have to come from the quarries in the distant plain. In addition, the sand obtainable from the local detritic covers was not of good quality, being rich in calcareous and evaporitic components; medium-quality products could be obtained, after sieving, from some alluvial deposits.

\section{DRILLING AND GEOLOGICAL SURVEYS OF THE TUNNEL}

In 1872, the contract was assigned to the 'Entreprise du Grand Tunnel du Gothard' by Louis Favre, an engineer and contractor from Geneva, with an offer to complete the works in eight years at an overall cost of 47.8 million francs; this was one year and 12 million lire less than the offer from the 'Società italiana per $i$ lavori pubblici' of the engineer Grattoni who, supported by Quintino Sella, proposed re-using the same qualified personnel and technical machinery already used for the Mont Cenis (Fréjus) tunnel (PAVARIN, 2020). The drilling machinery was thoroughly tested, and dynamite (a recent invention by Alfred Nobel, patented in 1867) was now available in the field of civil engineering.

The contract between the management of the 'Gotthardbahn-Gesellshaft' (Gotthard Railway Company) and Favre for building the 'Grossen Gotthardtunnel' was signed on August $7^{\text {th }}, 1872$, initiating works which, troubled by labour unrest and the deaths of at least 177 workers, were concluded on February $24^{\text {th }}, 1880$, when the last rocky diaphragm was broken: the tunnel was inaugurated on May 23 ${ }^{\text {rd }}, 1882$, connecting the cantons of Ticino and Uri and inaugurating the direct railway line between Milan and Zürich, the main transalpine axis between north and south Europe. It was an immediate success.

Geological study of the tunnel had been warmly proposed by Bernhard Studer (1794-1887), chairman of the Swiss geological commission, the best expert in the Alpine geology of the times. Reliefs during excavation for the tunnel were made in 1873 by C. Dress and, in the following four years, by F.M. Stapff, an engineer and geologist of the Gotthardbahn, responsible for sampling and monthly reports to the works management and the Swiss Federal Council. The work was briefly described in the monograph by STAPFF (1880): 'Profil géologique du St-Gothard dans l'axe du Grand Tunnel établi pendant la construction (1873-1880)', a special supplement to the reports of the Swiss Federal Council on the progress of work by the 'entreprise du St-Gothard' (for specific geological and technical details, including the description of the samples collected, see 'Geologische Tabellen und Durchschnitte ueber den grossen Gotthardtunnel', a special insert to the reports of the Swiss Federal Council on the Gotthard railway tunnel).

The monograph contains a coloured table with the geological profile of the tunnel from Airolo to Goeschenen, scale 1:25,000, with legends in French and German, executed by F.M. Stapff (Fig. 4). The geological description was subdivided into four sectors, from Switzerland to Italy, each with its own legend: i) the Finsteraarhorn massif, from Goeschenen to the Reuss river: gneissic granite, with intercalations of gneiss and porphyry dykes; ii) the Ursern basin, the alluvial plain of Andermatt: two subsurface synclinal folds, both subvertical and with round hinges, separated by a sheared anticline, the former composed of Ursern gneiss with quartzose banks and green rocks and a core of 'cipollino' marble and the latter of sericitic Carboniferous black schists; iii) the Gotthard massif, as far as Alpe Sorescia, including the Glockenthurmli, a watershed between the North Sea and the Mediterranean: it is composed of repeated alternations of various types of gneiss passing to micaschists, with a serpentinitic body and a few intercalations of amphibolitic rocks, and a fanshaped structure, disarticulated in its central-northern sector by systems of faults with normal kinematics; iv) the Tessin basin, to the slope of the Val Bedretto south of Airolo: the southern sector of the Gottardo fan, composed of alternating gneissic schists, black granatiferous micaschists and carbonatic schists with repeated stratoid intercalations of amphibolitic rocks and quartzitic schists, lying on the dolostone, marble and carnieule unit of Airolo.

Stapff's profile of the tunnel substantially confirms Giordano's forecast, with differences mainly due to the greater detail made possible by the larger scale. The main novelty was the brittle tectonics represented by Stapff and more easily identified in the tunnel than on the surface. Instead, the pair of cylindrical synclinal folds drawn by Stapff in the subsoil of Andermatt are the CarboniferousJurassic layers of the Urseren-Gavera shear zone, crossed 


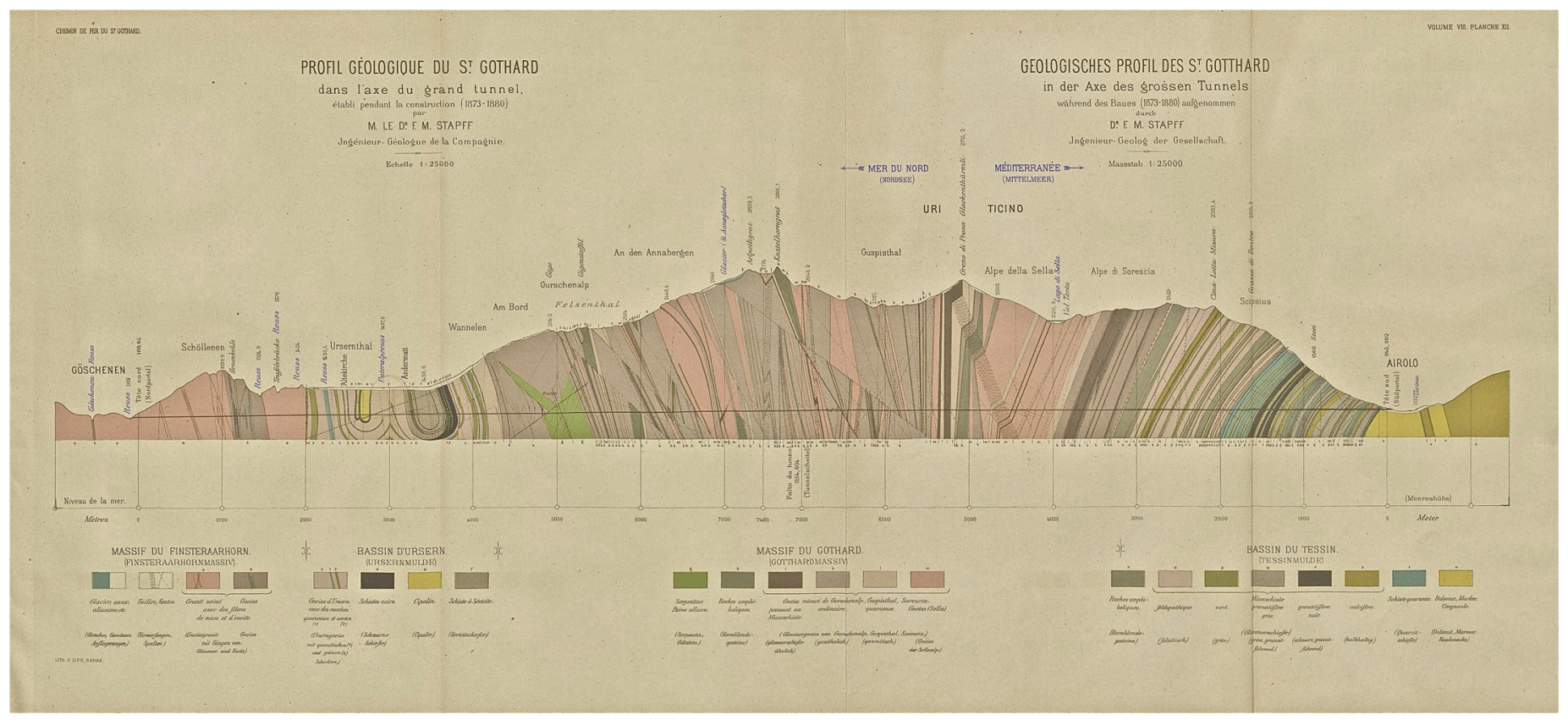

Fig. 4 - Geological profile of the St Gotthard at 1:25,000 scale along the axis of the Great Tunnel, elaborated by the engineer-geologist F.M. STAPFF (1880) during the advance of tunnelling (1873-1880).

by the modern St Gotthard motorway (ZANGERL et alii, 2006); 700 metres below is the base tunnel of the railway, $57 \mathrm{~km}$ long (a world record), inaugurated on May $1^{\text {st, }}$, 2016, after seventeen years of work (GuNTLI et alii, 2016).

\section{BARETTI'S GEOLOGICAL PROJECT FOR A BASAL RAILWAY TUNNEL UNDER MONT BLANC}

Martino Baretti, born in Turin, with a degree in natural sciences from Bologna, had occupied the chair of geology at the University of Turin, succeeding Bartolomeo Gastaldi, his master; then, from 1871, the chair of geology and mineralogy at the local industrial and professional institute. A tireless mountaineer, in 1871-1872 he had drawn up, accompanied by Gastaldi, the geological map of the Dora Riparia valley, and then, alone, maps of the Emilius (1973-1875), Gran Paradiso (1877), northern Graian Alps (1879) and the Mont Blanc massif (18781880) - an immense task crowned by the monograph 'Geologia della Provincia di Torino' (1893), with a geological map, scale 1:50,000.

Baretti had produced the geological relief of the Mont Blanc massif for the provincial authorities of Turin and under the auspices of the the Comite local d'Aoste, promotor of the tunnelling of Mont Blanc; he had then concluded this work with the monograph 'Apercu géologique sur la Chaine du Mont Blanc en rapport avec le traject probable d'un tunnel pour la nouvelle ligne de chemin de fer', published in 1881. His main aim was to predict correctly 'quelles roches et dans quelles conditions de stratification on aurait rencontrées dans le percement d'un tunnel selon une direction et à une profondeur données', thus confuting the complaints of the Sempione supporters, who believed that a tunnel under Mont Blanc was impossible (e.g., Colladon, 1880).

For the necessary topographic work, Baretti used the project of the engineers de Lepinay and Chabloz, similar to that of Bonelli and published in 1880. It extended from Morgex (26 km beyond Aosta) to Taconnaz (High Savoy, $4.5 \mathrm{~km}$ south-west of Chamonix), traced at 1,000 $\mathrm{m}$ a.s.l., with curves and pendences within the limits foreseen for a railway line of the times: overall, it measured $24,810 \mathrm{~m}$, of which $20,710 \mathrm{~m}$ in a tunnel and a rocky cover which exceeded $3,000 \mathrm{~m}$ in its central part. It was a grandiose project, and a precursor of modern railway base tunnels.

The geology of the Mont Blanc tunnel is shown in three documents, scale 1:50,000: Esquisse géognostique (Tab. I), Coupe longitudinale (Tab. II) and Coupe horizontale (Tab. III), showing the railway both on land and in tunnels, the 130 field points at which Baretti had described and measured the 'stratification' of the sedimentary formations, granite (in fact, ductile and brittle anisotropies) and the encasing crystalline schists. These measurements are discussed in the text, together with how the stratification on the advancing front would appear if the direction of the tunnel was changed. The work is divided into three main sectors, proceeding from the valley upwards (Fig. 5).

First Sector - Length 4,210 m, with open tracts and two shallow tunnels, extending from Morgex to Champey (Champex), at the foot of the valley step rising from the plain of Prè-St-Didier (1,004 $\mathrm{m}$ a.s.l.) to Courmayeur $(1,224$ $\mathrm{m})$. South of Morgex is the boundary between 'alluminal' (clayey) and micaceous Carboniferous schists and the underlying crystalline calc-schists, i.e., between the middle Penninic (Zone houillère, Briançonnais) and the external Penninic (Sion-Courmayeur, Brecce di Tarantasia; DE Giusti et alii, 2004): they are described as a complex of calc-schists and local crystalline marble with regular beddings, believed to be solid and easy to drill. Beyond the confluence of the Dora di Verney, the railway route runs along the detritic, morenic and alluvial materials of PrèSt-Didier for $1,170 \mathrm{~m}$, as far as Champey (1,036 $\mathrm{m}$ a.s.l.), where the second sector begins. 


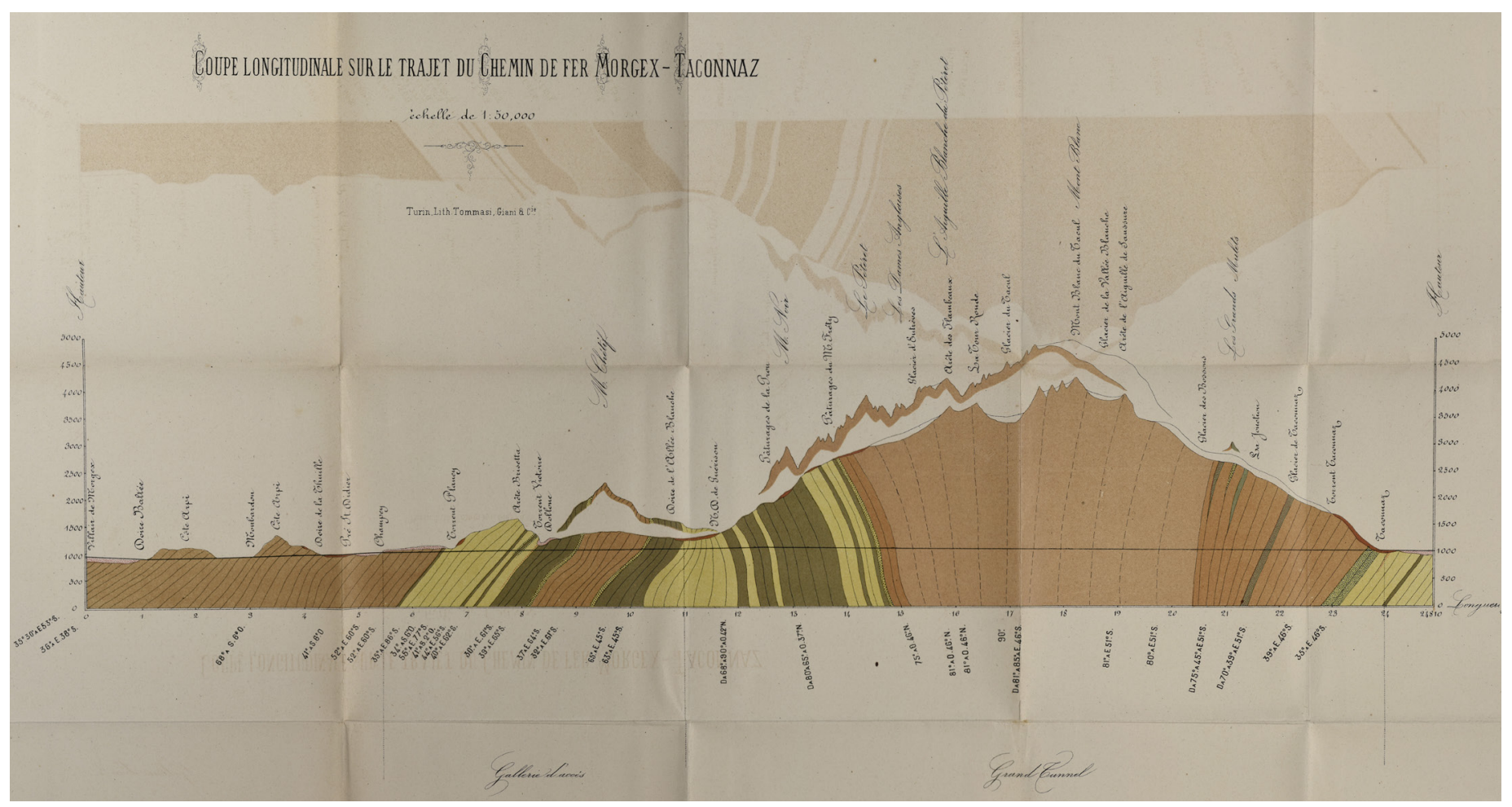

Fig. 5 - Mont Blanc railway base tunnel conceived by BARETTI (1881): longitudinal section along the route Morgex-Taconnaz, 1:50,000 scale, with the "Galerie d'access" et le "Grand tunnel".

Second Sector - This is called the 'Galerie d'access', 5,525 $\mathrm{m}$ long, all underground. It passes under the Arpy valley, Mt. Brisetta (Brisè), the village of Dollone (Dolonne) and Mt Chétif, as far as the subsoil of Entreves. This tract, subdivided into five sections, was believed - rightly - to present the most complex lithological and technical problems, so that Baretti thought it was opportune to supply 'de plus grand détail sur la nature et la disposition des formations géologiques', including precise data of their attitude.

Section 1 - In the first 1,150 m, as far as the subsoil of the Planey stream, the tunnel crosses calc-schists identical to the preceding ones and distinguished only by intercalations of micaschists and quartz schists. The layers were solid and easily drilled.

Section 2 - In the next 1,650 m prevalent dark-grey schists were foreseen, compact or semi-crystalline, with repeated intercalations of black micaceous-quartzose schists, crypto-crystalline quarzites and, in the final stretch, also chalk-anhydrite with altered limestone. It is pointed out that the scale of the figures is too small to show a complete representation of these intercalations in the calcareous mass.

Section 3 - $800 \mathrm{~m}$ long, beyond the Mt. Brisetta calcareous formation follows the underlying micaceous schists, with cavernous limestone, shiny slate and zoned limestone which, in turn, lie on the crystalline basement of Mont Chétif, through a thin layer of white marble (Penninic-Helvetic tectonic boundary). Good general conditions of solidity, presenting no difficulty to drilling.

Section $4-1,175 \mathrm{~m}$ long, this section obliquely cuts the crystalline basement of Mont Chétif, composed of hard, solid rocks, regularly bedded in banks $0.30-2.50 \mathrm{~m}$ thick. From south (roof) to north (bed) the following rocks appear: euritic schistose gneiss (metamorphic porphyry), fine-grain or coarser, with large crystals of feldspar, gneiss with granitoid structure from weak to accentuated, similar to foliated protogine, and various types of minute gneiss. The attitude of beds appears to be constant, plunging SE and tilting between $65^{\circ}$ and $52^{\circ}$.

Section 5 - $750 \mathrm{~m}$ long, this section describes a curve at a depth of about $180 \mathrm{~m}$, running as far as the confluence of the Dore of Ferret and Veny, near Entreves, where the third sector begins. Here are clayey schists with intercalations of black limestone, following by dominant solid and resistent blue marble, appearing in the wall above Notre Dame de la Guerison (cover successions of the Helvetic Zone).

Third sector - Called the 'Grand Tunnel', this sector is $13,100 \mathrm{~m}$ long, passing in a straight line the entire massif of Mont Blanc and its characteristic fan shape, already drawn by preceding authors and confirmed by Baretti with precise measurements. It passes under the glacier of Entreves, the Tour Ronde $(3,792 \mathrm{~m})$, Mont Blanc du Tacul $(4,249 \mathrm{~m})$, the Grand Mulets $(3,050 \mathrm{~m})$ and the tongue of the Taconnaz glacier, the last $765 \mathrm{~m}$ being in the open air. Its description is subdivided into five sections.

Section 1 - 3,625 m long: clayey-calcareous beds, identical to those of the last tract of the access tunnel and their continuation (Helvetic, Pavillon-Col Ferret unit in the Foglio Monte Bianco: alternations of limestone, marl and black schist).

Section 2 - Narrow zone of schistose crystalline rocks (marginal cataclastic belt of granitic basement with porphyroids and impregnations of quartz), plunging N316 by $75^{\circ}$. 
Section 3 - 5,550 m long: protogine, fan-shaped and divergence upwards, 'qui peut être considérée comme la juxtaposition par pression des deux jambes du grand pli, ce-qui imprime un caractère particulier à la structure générale de la châine' (i.e., the eroded anticline of Favre and Zaccagna). The first 2,050 $\mathrm{m}$ belong to the southern limb of the presumed anticline, narrowed at the base, and the next $3,550 \mathrm{~m}$ to the northern one, with many measurements of the protogine 'stratification' (brittleductile foliation) and tabular feldspar on the surface, near the Entreves glacier (protoginic leptinite), between the glaciers of Toula and Entreves (leptinite), Aiguille de la Brenva (typical protogine), Tour Ronde (idem), Capucin du Mt Blanc du Tacul (idem) and Aiguille du Midi (idem). According to Baretti, the protogine is a rock with accentuated granitoid structure, composed of hyaline quartz and milky-white or grey feldspar, with chlorite, talc (white mica) and sometimes small flakes of mica (biotite). The rock is compact, solid to all tests, but not very resistent to drilling, because the quartz is brittle and the feldspar exfoliates along the cleavage, but overall it guarantees solidity due to aggregation of the crystals, the thickness of the banks (exceeding 10-12 m) and their direction, roughly orthogonal to the axis of the tunnel. Therefore, it was not necessary to cover the tunnel wall with brickwork, except in some places where the protogine passed to very fine quartzose-feldspathic leptinite. Baretti's general expectations were substantially correct, although he may have not known about the possibility of rockburst in the vault, a problem recognized and expected by FRANCHI et alii (1908), but again under-evaluated many years later probably also by Bibolini (ZIGNOLI, 1966) and one of the main sudden difficulties found during excavation of the tunnel.

Section 4 - Zone of crystalline schists, similar but more developed and thicker than section 2 (in fact, it is the pregranitic polymetamorphic basement of the French sector). According to surface observations, these are prevailing scistose gneiss rich in mica and others with quartz nodules (now interpreted as paragneiss and anatectic migmatites older than the granitic intrusion) with intercalations of schistose rocks, including crystalline marble at the base of the Aiguille du Midi, the serpentinitic (chloritic-amphibolic) schists of the Grand Mulets, and the amphibolites of the Mur de la Côte. There is no evidence establishing whether these intercalations extend in depth as far as the plane of the tunnel - something which Baretti believed was probable - but in any case irrelevant, due to the quality of the rocky mass, which was prevalently gneissic, very solid, and not difficult to drill.

Section 5-475 m long: a thin zone of calcareous-clayey terrains, a repetition of section 1 (Helvetic: décollement cover units), with morainic deposits at the French point of entry.

\section{GEOLOGICAL AND TECHNICAL FORECASTING}

The drilling of the tunnel (totalling 20,710 m) of the planned Morgex-Taconnaz railway line shows the following features: i) 10,175 $\mathrm{m}$ in very solid rocks (gneiss and protogine granite), probably not requiring masonry cover, especially for the $5,600 \mathrm{~m}$ of protogine; ii) 5,235 $\mathrm{m}$ in calc-schists, almost as solid as the preceding rocks; iii) $7,115 \mathrm{~m}$ in limestone, slates, schists and quartzites, very solid, apart from occasional exceptions; iv) $185 \mathrm{~m}$ in altered calc-schists, which required care. The stratigraphic conditions were favourable for drilling and excavating. Large-scale infiltrations of water were not expected, thanks to the enormous pressure of the rocky load above, which compressed the strata and closed fractures (infiltrations turned out to be copious in the Italian side).

In conclusion, these were Baretti's words: 'Nous répétons encore, que le but de cette relation est de tranquilliser l'opinion publique sur les difficultés géologiques qu'on pourrait rencontrer dans ce travail grandiose, difficultés éxagérées malignement par les adversaires du project'.

The monograph ends with a short evaluation regarding the project of a more superficial tunnel, limited to the Grand Tunnel alone. This would reduce the subterranean tract to just over $15 \mathrm{~km}$ and avoid the critical formations of the Dolonne valley (sheared Penninic front thrust, with cataclasite, carnieule and evaporite) - the situation which had supplied the pretext to adversaries to the Mont Blanc tunnel. It was this solution which was to be chosen eighty years later - but for a road tunnel, not a railway.

Baretti was a staunch supporter of the stratigraphic and chronological concepts of his master Gastaldi, shared by Zaccagna, regarding the sedimentary nature of the 'stratified rocks' of the Alps, including the protogine and their older age - convictions which were confirmed in the opus magnum of the Province of Turin (translated): 'like the central gneiss, the protogine of Mont Blanc, the Valpellina syenitic ones are not eruptive rocks; they are stratified, sedimentary, modified in their structure and mineralogical constitution due to metamorphism' (BARETTI, 1893, p. 151-152). The opposite view was held by Michel-Levy (1890) and PEARCE (1898), the first to clearly sustain the magmatic and intrusive nature of the Mont Blanc granite which, after almost a century, was dated to the Late Carboniferous (313 Ma: BAGGIo et alii, 1967; $304 \pm 3$ Ma: Bussy \& Von Raumer, 1994).

\section{THE SIMPLON RAILWAY TUNNEL}

The prospect of a railway tunnel under Mont Blanc, rivalling that of Simplon, gained new vigour when the French and Italian governments decided to extend their own railways respectively to Chamonix and Aosta, reducing their distance to only $51 \mathrm{~km}$ (VACCARONE, 1866). The first train had reached Aosta on July $5^{\text {th }}, 1886$, and the French engineer STAMm (1874) repeated the proposal of a tunnel under Mont Blanc, stating that, for France, it would be more useful than the Simplon. After preliminary research, Stamm and Leone Maineri had prepared a detailed project involving a tunnel of $11.5 \mathrm{~km}$ between Chamonix and Entreves, and had presented it to the Societé industrielle of Mulhouse (1874) and then to Milan (1875): also in this case, the project did not include any specific geological evaluations. In August of the same year, Stamm wished to present his project to the International Congress of Geographical Sciences and attract funds; however, after his arrival in Paris, aged only 41, he died of cholera on August $2^{\text {nd }}, 1875$ : with him, one of the main supporters of the Mont Blanc railway tunnel was lost (DAL PIAZ \& ARgENTIERI, 2019).

Once the railway tunnels of the San Gottardo (1882) and Colle di Tenda (1900) had been built, hopes for Val d'Aosta were once again dashed. Competition between 
the Mont Blanc tunnel, promised by Napoleon III to the Savoiards, and the Simplon tunnel, between Val d'Ossola and the Canton Vallese, was won by the latter, with much support from Milanese, Swiss and German interests (Duc, 2001; Puschnig \& Graeser, 2006; Cialdini, 2011).

The geology of the Simplon region had long been the subject of detailed research and contrasting interpretations (SchardT, 1903a; Rosenberg, 2020, Fig. 6). The geological study for the tunnel was carried out and finished in 1887 by three eminent scientists: Renevier from Lausanne, Lory from Grenoble, and Heim from Zurich (RENEvIER, 1883; BAuD, 2019). The tunnel, planned by the Swiss engineer Julius Dumur, passed under M. Leone $(3,552 \mathrm{~m})$ and was 19,803 m long, from Iselle (Varzo, $668 \mathrm{~m}$ a.s.l.) to Brig (633 $\mathrm{m})$, its highest point reaching $705 \mathrm{~m}$. Works, directed by the Prussian engineer Carlo Brandau, began in August 1898 with the excavation of a main tunnel and a secondary service one, and were both terminated on February $24^{\text {th }}$, 1905. The inauguration ceremony took place on May $19^{\text {th }}$, 1906, in the presence of Vittorio Emanuele, King of Italy, and Ludwig Forrer, president of the Helvetic Confederation. Regular train services began on June $1^{\text {st }}, 1906$.

For 75 years, the Simplon was the longest railway tunnel in the world - also mentioned because of the various difficulties it had involved, including high-pressure flooding, temperatures exceeding $50^{\circ} \mathrm{C}$, and also the loss of many lives. About 3,000 men had worked every day, and 1520 tons of dynamite had been used to remove one million cubic metres of rock.

Geological studies and applications during excavation were provided by RENEVIER (1899), SCHARDT (1903a, 1903b, 1905), Heim (1904) and Stella (1906). The geological section revealed by the tunnel clearly showed the validity of the new nappe theory, from the external decollement cover nappes to the axial and inner metamorphic basement and cover units of the Pennine and Lepontine Alps, piled in a
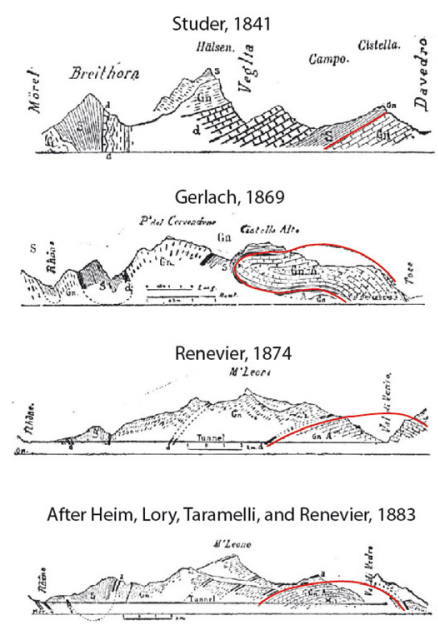

Projets 1890-1993

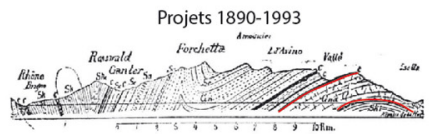

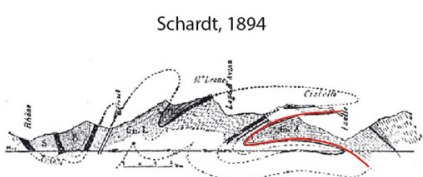

Traverso, 1895

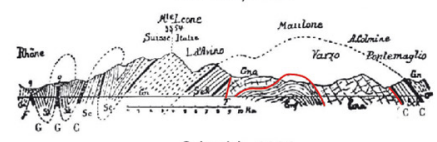

Schmidt, 1901
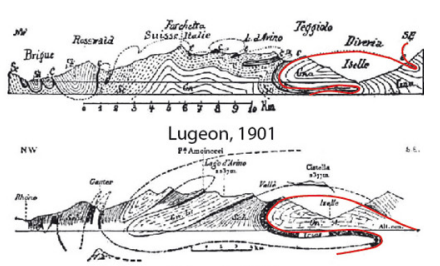

Schardt, 1903

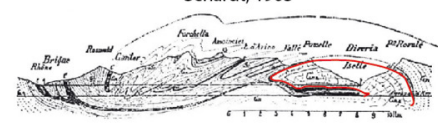

Fig. 6 - Evolution of the geological interpretation of the Simplon core of the Western Alps through the $2^{\text {nd }}$ half of the $19^{\text {th }}$ century, documented by a series of sections (RosENBERG, 2020, modified from SCHARDT, 1903). series of recumbent fold-nappes excellently reconstructed by Lugeon (1902), Schardt (1903a, 1906, 1909), LugEON \& Argand (1905) and Argand (1909, 1911). Milnes (1973), Masson (1983), Dal Piaz \& Dal Piaz (1984) and Rosenberg (2020) provide more details. The Simplon region was studied by SchmidT (1907) and mapped (scale 1:50,000) by Schmidt et alii (1908) and by Stella (1890) who had prepared the original maps, scale 1:25,000, for Sheet 5 (Val Formazza) and Sheet 15 (Domodossola) of the Geological Map of Italy, scale 1:100,000, followed by a structural interpretation (STELLA, 1905) against the nappe theory, still based on fixist tenets of the Geological Survey.

The Simplon tunnel crosses the following six nappes, from south to north: i) Antigorio, basement and a few Mesozoic units; ii) Lebendun, basement and covers; iii) Monte Leone, basement and a few cover metasediments; iv) Berisal (Grand St. Bernard); v) Sion-Courmayeur cover units (external Penninic); vi) Mesozoic décollement units of the inner Helvetic zone (Bigr et alii, 1990; Dal Piaz, 1992; STECK et alii, 1999, including details on lithology).

\section{NEW HOPES FOR THE MONT BLANC TUNNEL AND FURTHER DISAPPOINTMENTS}

In the same period, Duparc \& Mrazec (1898) had published their monograph entitled 'Recherches géologiques et pétrographiques sur le Massif du Mont-Blanc', with a geological map, scale 1:50,000, surveyed between 1890 and 1896. Their work supplied a modern geologic and petrographic description of the granite and the roofing schists, and provided the innovative concept of dynamic metamorphism. Many basic data were taken from the doctoral thesis in petrography by MRAZEC (1892), entitled 'The protogine of Mont-Blanc and the accompanying eruptive rocks': this work confirmed the igneous nature of the protogine and contained a section, scale 1:20,000, of the Italian flank, from Entreves to the Col du Géant, and profiles, scale 1:40,000, crossing the regional structures from Mont Chetif and Val Veny to the Vallée de Chamonix. In the meantime, the Italian side of the Monte Rosa massif and Valsesia had been carefully studied by Artini \& Melzi (1900).

Once the Simplon had been finished, it seemed that the right moment had come to turn to Mont Blanc. However, nothing was done and, awaiting the railway, the Turin engineers Gonella, Silvano and Coggiola presented an over-ambitious project for a high mountain road between Courmayeur and Martigny, across the Col Ferret (2,543 m a.s.l.) and involving 44 hairpin bends. The technical study for the Italian tract, prepared by the engineer Prof. V. Baggi, is illustrated with plans, topographic sections and fine photographs of the Val Ferret and its glaciers (GonELLA et alii, 1906). However, it was not accepted.

\section{Monod’s Mont Blanc PRoJect and Related Geological STUDIES}

The idea of a railway tunnel under Mont Blanc was again relaunched in 1908 by the Valdostan deputy Francesco Farinet, the French engineer Arnold Monod and related Syndicat. Monod had presented a project of four possible paths to a delegation of French and Italian 
members of Parliament who had met at Aosta during a visit by the leaders Giolitti and Clémenceau, suggesting the shorter version $(12.5 \mathrm{~km})$, the solution which was later followed also by the French ministry of public works. The Monod project was based on the detailed geological study prepared by Franchi, Kilian and Jacob (FRANCHI et alii, 1908) for the Syndicat d'études du tunnel du Mont-Blanc et de ses voies d'accès, and subdivided into three unpublished documents: i) 'Rapport géologique sur les projets de tunnels', with the names of the three authors; ii) 'Etude géologique de la zone des rampes d'accès d'Aoste aux tunnels du Mont Blanc', by Franchi; iii) 'Etude sur la rampe d'accès des tunnels du Mont Blanc entre Oex et Chamonix', by Kilian and Jacob.

We present below an extensive summary of the first report, the most important of all the documents. It begins with a geological picture of the Mont Blanc massif and the neighbouring regions which were involved in the north-west trending, $2 \mathrm{~km}$ wide 'faisceau' of the planned four tunnels, from north to south: the Chamonix syncline (Liassic), fan-shaped Mont Blanc massif (crystallinegranitic basement), Veny-Ferret or Entreves syncline (Liassic), Mont Chetif-La Saxe ridge (porphyry), and the southern layers (Triassic-Jurassic) of Dolonne and Vallon de Checouri (Checrouit). In modern interpretations, these were the Helvetic and Ultra-Helvetic basement and cover units, the mélange of the Penninic frontal thrust (DolonnePyramides Calcaires) and, south of Dolonne, the external Penninic units of the Brecce di Tarantasia (Elter \& Elter, 1965; De Giusti et alii, 2004).

The geological sections of the four tunnels, called Projects A, B, C and D, scale 1:50.000 (attached to the report) are shown here in Fig. 7. They were constructed according to the geological map of DuparcK \& MrazeC (1896) and new terrain observations by Kilian and Jacob (French side) and Franchi (Italian side).

The report lacks a topographic map with the traces of the four projects, that we may desume from their description in the text. They extend from the Aosta Valley to the left flank of the Val d'Arve (Chamonix). Project A is the longest tunnel A (17 km): it begins at $1060 \mathrm{~m}$ a.s.l., slightly north of Prè-St-Didier, as the base tunnel described by Baretti, and has its French entrance near Taconnaz (1080 $\mathrm{m}$ a.s.l.). Projects $\mathrm{B}$ and $\mathrm{C}$, respectively 15 and $14.7 \mathrm{~km}$, have their Italian entrance at the base of the southern wall of Mt Chetif, north of Dolonne (Courmayeur), the former near the village of Villette $(1200 \mathrm{~m}$ a.s.l.) and the latter slightly further west; the French entries are respectively located above Tissours, at the foot of Les Pelerins (B, $1085 \mathrm{~m}$ ), and above Grange Neuve, on the left flank of the Bosson glacier $(\mathrm{C}, 1105 \mathrm{~m})$, now greatly regressed. Project $\mathrm{D}$ (shown as $\mathrm{C}$ in some of Franchi's descriptions) is the shortest $(12.5 \mathrm{~km})$, and has its Italian entry point west of Entreves, approximately corresponding to the entry of the present highway tunnel, and the French one slightly south of Granges Neuves (1180 m a.s.l.)

\section{The Italian sector}

The project for Tunnel A begins south of Prè-St-Didier, crossing non-cemented and highly permeable Quaternary deposits for $750 \mathrm{~m}$, capable of producing "les plus grandes difficultés" and requiring special techniques, such as those used for the clayey-sandy fault zone of the Col di Tenda tunnel (BALDACCI \& FRANCHI, 1900). The rocky substrate is composed of Jura-Liassic calc-schists, terrains which then continue along the axis of the tunnel for about $1200 \mathrm{~m}$, with intercalations of belemnite-rich facies, crystalline limestones, sedimentary breccias and a few greenstones (FrANCHI et alii, 1908 b): these are the 'schistes lustrés' of the French geologists and the 'Zona delle Pietre Verdi' (greenstone zone) of the Italians.

These are followed, to the north and underneath, by a large antiformal belt of dolomitic limestones, vacuolar dolomites, chalky and anhydritic bodies of middle-late

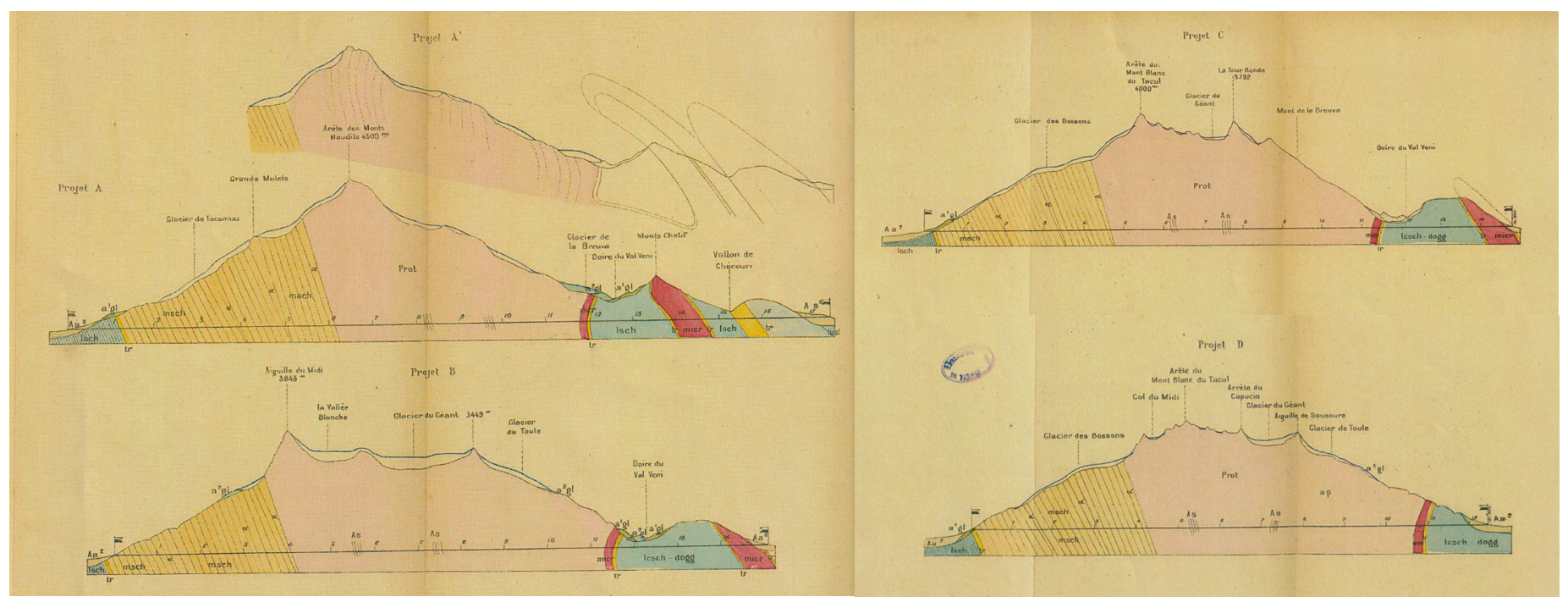

Fig. 7 - Geological sections at 1:50,000 scale of four projects (A-B-C-D) for the Mont Blanc tunnel (Monod's plan) elaborated by Franchi, Kilian and Jacob, inedited report (FrancHI et alii, 1908). A': paired antiformal interpretation of the Mont Chetif sheared 'microgranulites' and Triassic southern inlier. Legend: Protogine (Prot), schistose zones of protogine (As, pink); 'microgranulites' (igneous and volcanic rocks) of Mont Chetif and inner Mont Blanc (Mcr, reddish); gneiss, micaschists, sericitic schists etc (msch, light yellow); amphibolitic bands ( $\alpha$ ); Triassic dolostones, cargneules, chalks (tr, yellow); calcareous Liassic limestone and 'schistes lustrés' (lesch, light blue); hold alluvial-glacial deposits (agl), recent alluvial-glacial and till deposits (Agl). 
Triassic age, with scattered outcrops and sinkholes in the area of Checourì-Chapy-Dolonne. This is 'une très mauvaise zone' (a very bad area) for the drilling works, involving technical difficulties and possible watershoots, as foreseen by comparisons with similar rocks found in the Teggiolo syncline of the Simplon tunnel (SCHARDT, 1903a, 1903b). To the north, further calc-schists of Liassic age bordered by a thin belt of crystalline limestone, often rich in crinoids, with banks of quarzite and baritine, which end the Mesozoic successions of Franchi's Courmayeur syncline.

These terrains lie concordantly on the prominent Mont Chetif-La Saxe ridge, at the southern base of which are planned the entries of Projects B and C. This igneometamorphic body, $900 \mathrm{~m}$ wide, is formed of massive to layered or schistose porphyry with intercalations of 'microgranulites', i.e., fine-grain white-mica granite (DE LAPPARENT, 1883, p. 568). These rocks are difficult to perforate, but have the advantage of allowing a proper motorway tunnel to be constructed, without walling; the materials are dry, although local infiltrations are due to the largest of the subvertical fractures, which cut the flank of Mont Chetif opposite Courmayeur.

Two alternative interpretations are proposed for the structure of the Mont Chetif-La Saxe ridge: 'écaille, pli déversé ou lame de charriage' (for Kilian and Jacob, in accordance with the new nappe theory); Franchi does not share this hypothesis, believing it to be in contrast with the regular path of the calc-schistose layers around the porphyric mass. More generally, Franchi preferred folding without any substantial faults or thrusting, i.e., that 'in place' (autochthonous) setting which he maintained, together with his colleagues of the Geological Service, for the structure and generation of the Western Alps, from the Piedmont zone (Monte Rosa-Gran Paradiso) to the Grand St Bernard massifs and Mont Blanc (Franchi, 1906, 1907; STELLA, 1927).

North and under the Mont Chetif-La Saxe porphyry, tracks A-B-C cross the Mesozoic layers of the VenyFerret syncline (Entreves) for almost $2 \mathrm{~km}$, including dark crystalline and marly limestones, crenulated black slates, grey-bluish limestones (e.g., Notre Dame de la Guerison), with pyrite crystals and traces of belemnites (Pavillon du Mont Frety). The successions are dated to the Lias and related to the Dauphinois facies (FRANCHI et alii, 1908 b; EPARD, 1989). Approaching the contact with the Mont Blanc granite are the layers of the Entreves syncline which, throughout the southern tract, dip south-east by about $45^{\circ}$, gradually become vertical, and then plunge north-west at a high angle below the Mont Blanc crystalline basement: this is the well-known 'structure en champignon' (mushroom structure) or 'en éventail' of Mont Blanc.

The rocks of the Entreves syncline are easy to drill, although perhaps less stable along the tract where the rock above the tunnel reduces its thickness to less than 100 metres. In any case, the rocks are very permeable due to the fractures and a cover of fluvio-glacial deposits impregnated with water - a particularly critical situation in the tract below the confluence of the Dora rivers of Veny and Ferret valleys. The situation improves in the last kilometre of the Mesozoic syncline, with the calc-schistose successions of Mont Frety, which are essentially dry materials and easily drilled.

\section{Central parts of tunnels and french entrances}

The crystalline basement of Mont Blanc begins with a marginal hectometric facies of porphyry, 'microgranulites' and aplites, usually very hard and impermeable, with fracture zones cemented with diffuse hydrothermal impregnations of quartz.

The next granitic body (protogine) is mainly massive, with many diaclases produced by contraction resulting from cooling of the igneous mass and by the Alpine orogenesis. Within the sections, possible schistoselaminated areas have been sketched, probably rich in quartz veins and impregnations. This is followed by the micaschist complex, grouping gneiss, micaschists and seriticit schists, with lenticular intercalations of very hard amphibolites. The complex dips south-east by about $60^{\circ}$, like the planar limit with granite, outcropping in the French side of the massif (Fig. 7). Together, the micaschists and granites are generally very consistent, with hardness and resistence similar to those of the gneisses crossed by the Gotthard tunnel, the Antigorio gneiss in the Simplon massif, and the Albula granite. In particular, the similarity between the crystalline schists of the Gotthard and Mont Blanc and the identity of their granites is emphasised by ScHMIDT (1907).

The granites are also very brittle, with a high risk which - as happened in the Gotthard tunnel - gave rise to unexpected rockbursts, with great danger for workers (see discussion and references in SCHMIDT, 1907). As regards the micaschists, there was the problem of possible 're-swelling, pushing materials', capable of deforming or invading the tunnel. This was the problem at the centre of lively discussions between Albert Heim (1856), who believed in the 'latent plasticity of the rocks', which tended to close all empty spaces at depth, and the young Stapff and Schmidt, who denied the validity of this theory, having observed 'geodes and open fractures' in the Gotthard and Simplon tunnels. Franchi, Kilian and Jacob shared these criticisms and believed that 'they should not be feared', in spite of the considerable thickness and pressure of the overlying rock mass, to the extent that micaschists and granite could become so deformed that they filled the tunnel.

As regards probable veins of water, experience acquired while preceding tunnels were under construction (Mont Cenis, Gotthard, Albula, Simplon) allowed geologists to be 'very optimistic': within the micaschistic complex and the protogine, only dripping and a few small sources of water, fed by subglacial currents along the fracture systems, were to be expected. Only slightly mineralised waters were foreseen, with temperatures not exceeding those of the rock. Franchi added that the large sources of Péteret (Peuterey) and Tronchey, characterised by cold water (T $<5.5^{\circ} \mathrm{C}$ ), were the only ones which could be envisaged to come from the granites crossed by the tunnel, although it was more plausible that they were fed from the watertable in Val Veny and Val Ferret.

The entrances in the Chamonix valley of the four projected tunnels (Fig. 7) are located on glacial and alluvional deposits, which hide the terrains belonging to the internal border of the Chamonix syncline, composed of Liassic black shales and Triassic dolomitic and chalky-anhydritic layers, as shown also by the presence of dissolution sinkholes. They lie concordantly on the micaschists of the crystalline basement, in overturned 
succession, immerging to the south-east at $45^{\circ}-60^{\circ}$ (external part of the Mont Blanc fan).

The Quaternary deposits are generally mobile and highly permeable. The Liassic shales are impermeable, but generally not very resistant, requiring walling. With reference to the experience of the Simplon tunnel, special precautions will be necessary to cross the Triassic terrains, due to possible swellings and shoots of aggressive cold waters in the cases of $\mathrm{A}, \mathrm{C}$ and $\mathrm{D}$. The entrance to tunnel $\mathrm{D}$ is not very stable: it is situated on a moraine covering Triassic chalks, with possible deep cavities and yielding.

\section{Technical forecasts}

Considerable technical difficulties are foreseen on the Italian side for Project A, in the first $750 \mathrm{~m}$ of alluvional deposits and the areas of chalk, carnieules and muddy materials of Dolonne, defined to the north-west by a fault (the future Penninic frontal thrust; De Giusti et alii, 2004). Similar difficulties, but over much shorter tracts, are expected for the thin Triassic strips of the French entrances (Chamonix syncline). Fewer problems are foreseen when crossing several highly fractured and poorly resistent tracts of the Veny-Ferret (Entreves) syncline for projects A-B particularly for the latter. As regards project $\mathrm{D}$, the shortest and having an entrance near Entreves, difficulties are foreseen limited to the first $500 \mathrm{~m}$ of Quaternary deposits expected at the Italian side. As regards drilling works, Mont Blanc is an 'in-place' massif of crystalline-granitic composition, between Liassic synclines.

Waterspouts - Serious difficulties are foreseen in the Italian part of the Triassic zone of Dolonne (project A), due to the possibility of true high-quantity 'sources vauclusiennes' after rainy seasons. These waters and those of the chalks at the French entrances will be more or less mineralised (aggressive) and all probably cold. Other problems will be encountered in the Courmayer syncline, with probably very abundant waters for projects A and B and much smaller ones for project $\mathrm{C}$. The central parts of the tunnels (protogine and crystalline schists) will not give rise to large sources of water, which will have the same temperature as the rock, and there are no indications of dangerous large-scale shoots of cold water, like those which hindered works on the Simplon tunnel.

Temperature - According to Franchi's conclusions, in the pessimistic hypothesis that temperatures should not exceed $55^{\circ} \mathrm{C}$ in tunnel $\mathrm{A}, 52^{\circ} \mathrm{C}$ in tunnel $\mathrm{B}$ and $50^{\circ} \mathrm{C}$ in tunnel $\mathrm{D}$, the maximum temperatures may also fall to $48^{\circ} \mathrm{C}$, $45^{\circ} \mathrm{C}$ and $43^{\circ} \mathrm{C}$, respectively. According to the estimates of Kilian and Jacob and related geothermal profiles, the highest temperatures will reach $55^{\circ} \mathrm{C}$ at most, exceeding $40^{\circ} \mathrm{C}$ only in tracts of about $4 \mathrm{~km}$ for project $\mathrm{A}, 4.5 \mathrm{~km}$ for $\mathrm{B}, 5.5 \mathrm{~km}$ for $\mathrm{C}$, and $4 \mathrm{~km}$ for D. However, it seems prudent to estimate a maximum rock temperature between $48^{\circ} \mathrm{C}$ and $52^{\circ} \mathrm{C}$ in the central part of the tunnels - conditions which are definitely less severe than those of the Simplon.

This was the conclusive judgement of Franchi, Kilian and Jacob (translation): 'Taking into consideration the technical and hygienic precautions acquired by experience in already existing large-scale works (...), the project submitted to our evaluation appears perfectly achievable'. The Mont Blanc tunnel is similar to all the points in the
St. Gotthard tunnel and, to a certain extent, that of the Loetschberg (under construction). The considerable problems encountered in the central parts of the Simplon tunnel will not be found here, since the Simplon massif displays a completely different geological structure and of exceptional complexity: similar difficulties are foreseen only in the first few kilometres of the Italian tract of Project A, whereas the shorter Project D does not appear to present any serious difficulties.

This document was signed at Grenoble, on October $8^{\text {th }}$, 1907, by S. Franchi (Ingenieur au Corps Royal des Mines d'Italie), W. Kilian (Professeur à la Faculté des Sciences), Ch Jacob (Docteur Es-Sciences).

The two other reports, unpublished and shorter, are devoted to a brief geological and technical description of the 'access ramps to the Mont Blanc tunnel': the long tracts from Aosta to Entreves (Franchi) and from Oex to Chamonix (Kilian and Jacob).

\section{Regional research}

This applicative work and related forecasts benefitted from previous regional knowledge documented by the paper which Franchi had written with Kilian \& Lory (FRANCHI et alii, 1908) 'Sur les rapports des schistes lustrés avec les facies dauphinois et briançonnais du Lias', quoted contributions and field trips across the Val d'Aosta, in which FRANCHI (1907) had described and updated regional geology in the now classic section, from the Piccolo San Bernardo to the Mont Blanc massif (Fig. 8A). Franchi knew the area very well and, with his colleague Stella - engineers and excellent mappers of the R. Ufficio Geologico headed by Felice Giordano - had executed (scale 1:25,000) sheets 27 (Monte Bianco) and 28 (Aosta, western sector) of the Geological Map of Italy, scale 1:100,000, completed at the end of the century, with short explanatory notes (FrANCHI, 1899, 1901; STELLa 1901) and later sections (STELla, 1927, Fig. 8B).

It should be noted that the Mont Blanc sheet and almost all the other sheets of the Western Alps were not printed until 1912, when field work had long been concluded. The cause of this delay was due to disagreement on the age of the formation of the 'calc-schists and greenstones' which had arisen between Mattirolo and Zaccagna, orthodox defenders of the older age proposed by Gastaldi, and their young colleague FRANCHI (1898) who had demonstrated its Mesozoic age wholly in the Western Alps, with inevitable implications regarding the legend: this long dispute was finally resolved in 1911 in favour of Franchi by a commission composed of Torquato Taramelli and Carlo F. Parona, especially instituted by the Geological Committee (Dal Piaz \& Dal Piaz, 1984; Dal Piaz et alii, 2015; Barale et alii, 2018). The fall of the Clémenceau government in 1909, the retirement of the deputy Farinet and then the First World War meant that any well-based interest in the Mont Blanc tunnel was set aside for many years.

\section{Renewed interest in the Mont Blanc tunnel}

After the First World War, the epidemic of Spanish flu and the following economic crisis meant that research work took place only very slowly. As regards Mont Blanc and the Aiguilles Rouges, there are the geologic map, scale 


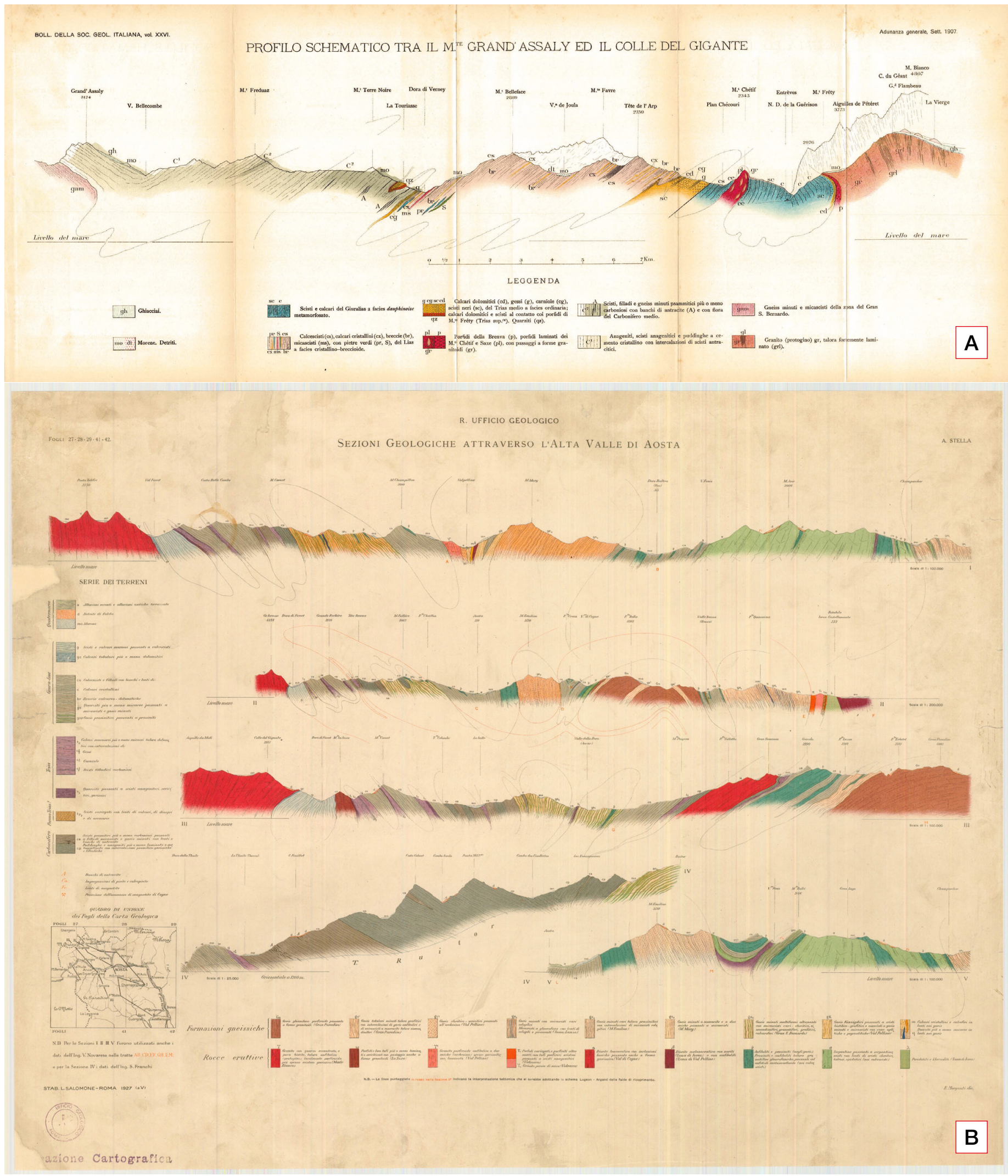

Fig. 8 - (A) Schematic geological profile along the right side of Aosta valley, from Grand Assaly (Ruitor massif) to Colle del Gigante (Mont Blanc) by Franchi at the general assembly of the Italian Geological Society (September 1907), according to his fixistic (autochthonous) views through a seamless sequence of folds. (B) Geological sections across the high Aosta valley, inferred from Sheets 27 (Monte Bianco) - 28 (Aosta) - 29 (Monte Rosa) - 41 (Gran Paradiso) - 42 (Ivrea) of the Geological Map of Italy at 1:100,000 scale, by Stella (1927), based also on data by Novarese (sections I-IV) and Franchi (section IV); dotted red lines indicate the tectonic interpretation that would be obtained by adopting the LugeonArgand scheme of fold-nappes. Drawing by Morganti. 
1:20,000 and studies by CoRBIN \& Oulianoff in the years 1920-1935, later taken up again and completed between 1952 and 1959; the study by PAREJAS (1922) on the syncline of Chamonix and those of Collet $(1924,1927)$ on the tectonic relations between the crystalline massifs of Mont Blanc and the Aiguilles Rouges; the petrographic notes on Mont Blanc and Mont Chétif by Michel-Levy (1928), Corbin \& Oulianoff (1930) and Sanero (1938, 1940), and also that on the tectonics of the protogine by Liechti (1934). The monograph by BELLIÈRE (1958) on the crystalline basement of the Aiguilles Rouges and that of BoRDET (1961) on the Belledonne massif, with references to Mont Blanc, complete the picture of our main regional knowledge at a time when work on the tunnel was just beginning.

Renewed interest in the Mont Blanc tunnel was mentioned in 1933 by the Italian newspaper Corriere della Sera in an article by Carlo Ciucci entitled 'An idea which is becoming reality. The Mont Blanc motorway'. This news mentioned the Italian senator Piero Puricelli, builder of the Milan-Lakes motorway, and Antoine Broon from Geneva, who had convinced Monod to return to his railway project and to present one involving a road tunnel. In 1934, during a congress at Bonneville of French, Italian and Swiss authorities, Monod himself had illustrated the new project: a road tunnel $12,620 \mathrm{~m}$ long, slightly longer than the one we use today, with entrances at 1,220 $\mathrm{m}$ a.s.l. at Chamonix and 1,382 $\mathrm{m}$ a.s.l. at Entrèves (DAL Piaz \& ARgentieri, 2019).

As an alternative, in 1936 the Piedmont engineer Emilio Chauvie had relaunched the unrealistic idea of Gonella et alii (1906) of a link with the Vallese along the high valleys of the Dora and Drance of Ferret, and had presented a project for a road between Courmayeur and Orsières, with a tunnel under the Col Ferret, 6,250 m long and an entrance at 1,790 $\mathrm{m}$ a.s.l. (JeLmoni, 1948). The project was examined again in 1944 by Chauvie, together with engineers Ferdinando Cena and Henry Chenaud (for details, see CENA, 1952). Yet again, the proposals were not accepted: relations between Italy and France, initially good, worsened with the fall of the Laval government, replaced in 1936 by the Popular Front, and were finally put aside due to the war in Ethiopia, sanctions to Italy and, later, the outbreak of the Second World War.

\section{DECISIVE MOVES TO COMPLETE THE MONT BLANC TUNNEL}

\section{The CREATIVE ACTIVITY OF LORA TOTINO}

During the later years of the war, the idea of a tunnel under Mont Blanc was taken up by Count Secondino (Dino) Lora Totino (1900-1980) from Biella, a young and eclectic entrepreneur with a degree in engineering from the Polytechnic of Turin. In 1944, he had asked his engineering professor, Vittorio Zignoli, to evaluate the feasibility of a permanent road link between Courmayeur and Chamonix and, receiving his assent, charged him with planning a tunnel aimed at attracting tourists. This tunnel, $12 \mathrm{~km}$ long and $5 \mathrm{~m}$ wide, for one-way alternating traffic, was later updated in 1946 as a two-way tunnel, $7.5 \mathrm{~m}$ wide and equipped with forced ventilation (ZIGNOLI, 1965). In the same year, Lora Totino had founded the Compagnia per il traforo and started his initiative by excavating from the Italian side, with an entrance at La Palud, near Entreves.
In 1947, the tunnel was 160-200 m long (according to sources), but work was halted by the local administrative and military authorities and not followed up later.

It was in fact an utopistic undertaking, but it did have the effect of relaunching the eternal problem of a permanent link between Courmayeur and Chamonix. Lora Totino believed in tourist development of the magnificent region and, already before the war, between 1934 and 1939, had built the first cableways from Cervinia $(2,050 \mathrm{~m}$ a.s.l.) to Testa Grigia-Plateau Rosà $(3,480 \mathrm{~m})$ and Furggen $(3,486 \mathrm{~m})$, and initiated the controversial urbanisation of the virgin Breuil area. After the war, he had acquired from the military authorities the cableway from Entreves to the Rifugio Torino $(3,375 \mathrm{~m})$, later extended to Punta Helbronner $(3,462 \mathrm{~m})$ and, lastly, the tele-cabin service of Vallée Blanche, between Punta Helbronner and the French Aiguille du Midi $(3,778 \mathrm{~m})$, again following the project of Vittorio Zignoli: this was a spectacular plan, 5,093 m long, which, in 1957, completed the cableway link between Courmayeur and Chamonix, shortly before works on the road tunnel began.

In the meantime, the deputy Paolo Farinet, nephew of Francesco Farinet, had worked hard on starting the Mont Blanc tunnel and obtained the political aid of Alcide De Gasperi and Luigi Einaudi. The situation had initially been uncertain, both because of French competition between High Savoy and the Dauphiné, the latter supporting a second (and now road) tunnel under Fréjus, and of the start of the Grand St Bernard project, linking Saint-Remy $(1875 \mathrm{~m})$ and Bourg-St-Pierre (1918 m); however, the Mont Blanc plan was finally accepted.

Referring now to the site of the Società Italiana per Azioni per il Traforo del Monte Bianco (SITMB), the first step in building the tunnel was the agreement between Italy and France for the construction and management of a road tunnel, which was signed in Paris on March $14^{\text {th }}$ 1953, and approved by the Italian Parliament on July $14^{\text {th }}, 1954$ and by the French National Assembly three years later, on April $12^{\text {th }}, 1957$. The ratification allowed the creation of companies carrying out the works and then management of the tunnel itself: i) in Italy Società Italiana per il Traforo del Monte Bianco (September $1^{\text {st }}$, 1957), chairman Ambassador F. Jacomoni di San Savino, Ceo the engineer G. Anselmetti, from Turin; ii) in France, the company Autoroutes et tunnel du Mont Blanc (June $\left.6^{\text {th }}, 1958\right)$, chairman Edmond Giscard d'Estaing, father of Valéry, the future President of the French Republic. After so many twists and turns and years of discussion, the great enterprise was about to be achieved.

\section{The Project of Vittorio Zignoli}

The first project planned by Zignoli, in 1946, had been used as a base for negotiations, intergovernmental agreements and decrees for building concessions and activating use of the tunnel (ZignOLI, 1965). The ItaloFrench agreement of 1953 involved: i) one roadway, 7 $\mathrm{m}$ wide, and two pavements for footpaths, the northern one being $0.80 \mathrm{~m}$ wide and the southern one $0.35 \mathrm{~m}$; ii) an entirely covered tunnel; iii) ventilation proportionate to traffic calculated at 250 vehicles/hour; iv) lighting to allow traffic to pass with side-lights only; v) an estimate of 5,500,000,000 lire for the Italian part and 5,000,000,000 lire for the French part. 
The topographic map of the tunnel - a difficult task, due to the high-altitude conditions and the extent of glacial areas - was prepared by Pietro Alaria who, years later, supplied a detailed report of it (AlARIA, 1976): begun in 1946, verified in 1951 and checked in 1957 by the engineer Lagrange, the topographic relief was completed in 1958 with a high-precision levelling operation carried out by the Italian and French geographical institutions.

In the meantime, the technicians on both sides had revised the original project and agreed on a new section to the tunnel, with the same width for the two pavements and more space for ventilation, proportioned to estimated traffic flows of 450 vehicles/hour and 600/hour during rush hours, at an average speed of $60 \mathrm{~km} / \mathrm{hour}$. Further variations were introduced during the work.

The final features of the tunnel were: length 11,600 m, width of double carriageway: $7 \mathrm{~m}$, width of pavements: $0,80 \mathrm{~m}$, gradient of the Italian section: $0.25 \%$, that of the French part: $2.4-1.8 \%$, height of the Italian entrance at 1,381 $\mathrm{m}$ a.s.l., $80 \mathrm{~m}$ above the bottom of the valley, height at the French entrance at $1,274 \mathrm{~m}, 260 \mathrm{~m}$ above the bottom of the valley, ventilation shafts under the roadway, concrete cover, lateral widened areas for emergency parking every $300 \mathrm{~m}$, alternating right and left, niches every $100 \mathrm{~m}$ with telephones and fire extinguishers, and safety apparatus for checking $\mathrm{CO}_{2}$ and visibility (for further details, see ZIGNOLI, 1965). Plans for the road deck and ventilation shafts were reviewed by CASTIGLIA \& CHIORINo (1967) of the Politecnico of Turin.

The planned project of 1946 was accompanied by a geognostic note by Aldo Bibolini (1946, unpublished and vainly sought), one of Zignoli's colleagues, without any reference to the three detailed reports of FRANCHI et alii (1908). During the work, the Italian company assigned professional consultations to profs. Luigi Peretti and Lelio Stragiotti of the Politecnico di Torino (various reports for 1959-1961, quoted in ZignOLI, 1965).

The French concessionary company chose a geological and geotechnical report by the engineer Bastien, based on a geological report by Lugeon and Oulianoff.

In the report of the final project, Zignoli (1965) devoted slightly more than one page to geology, noting that the geologists' forecasts 'were very comforting' - with a reference to Bibolini's note which, it seems, was limited to repeating the opinion of BARETTI (1881): this is presumed from the short description of the geology of the tunnel in which, starting from the Italian entrance: i) 'an initial area of particularly hard calcareous-schistose masses, the removal of which might have to be continued for about 1 $\mathrm{km}$ in favourable conditions', with only a few filtrations by water; ii) in the central area, 'after a porphyric belt which, at the depth of the tunnel, is foreseen to be compact and about $150 \mathrm{~m}$ wide', we reach the characteristic granite of Mont Blanc (protogine), associated with schistose rocks, passing sometimes to true micaschists, with quartz-rich aplitic dykes, rocks believed to be, in depth, 'poorly aquiferous, resistent and stable, extending for about 6.5 'km', whereas $3.5 \mathrm{~km}$ of 'compact schistose rock' were foreseen towards the French entrance. In the hydrological field, artesian sources were excluded and, if they existed, were believed to be small, poorly mineralised, and with a beneficial refrigerating effect (in reality, they were very different). The mylonitic belts, reported in other areas of the massif, if also present along the path of the tunnel, might require local reinforcements but, apart from this possibility, 'it is believed that, everywhere in the remaining areas, one could count on possible instantaneous rock falls, due to alterations in the pre-existing elastic equilibrium, altered by tunnelling'. As regards temperatures, Bibolini (in ZIGNOLI, 1965), clearly influenced by data from the Simplon, believed that the tunnel 'might be able, for one kilometer in the central part, to reach a temperature of $45-50^{\circ} \mathrm{C}^{\prime}$; Zignoli favoured a maximum temperature of $40-45^{\circ} \mathrm{C}$ which, according to the engineer Bastien, would not exceed $36-38^{\circ} \mathrm{C}$.

\section{From Field Surveys for Radioactive minerals to the Mont} BLANC TUNNEL

Shortly before the construction site was set up and tunnelling began, the Italian flank of Mont Blanc was subjected to geological fieldwork and detailed geophysical prospections, in a search for radioactive minerals. These led to the discovery that, along the tunnel trace on the surface, many fracture zones were marked by strips of cataclastic and mylonitic granite, sometimes with poor metalliferous mineralisation. Since 1954 in the Western Alps, two geological teams and prospectors for radioactive minerals, attached to the Divisione Geomineraria of Comitato Nazionale Ricerche Nucleari (CNRN, later CNEN), directed by Felice Ippolito, had been carrying out research (DAL PIAZ, 2018). These teams were: Group Alfa, headed by Paolo Baggio, and Group Beta, headed by Sergio Lorenzoni, both with degrees in Geological Sciences from the University of Padua. The main results of their investigations, complete with mineralogical, petrographic and geochemical analyses, were published in a series of monographs entitled Studi e ricerche della Divisione geomineraria $(1958,1959,1960)$, now difficult to find and unfortunately long ignored. Among the most significant contributions on the mineralisation of uranium and thorium in the Western Alps and their geological context were works by Mittempergher, Lorenzoni and Zanettin on the uraniferous deposits in the Permian of the Cottian and Maritime Alps (for references, see DAL PIAZ, 2018) and monographs by BAGGIO (1958) and FRANCESCHETTI (1960) on the granite of Mont Blanc and its mineralisations.

As he himself remembers, Baggio had begun to work on Mont Blanc in 1956, when he was asked by the Divisione Geomineraria to direct prospections in the region. Fieldwork was carried out in 1956-1958 in the area between the Brenva glacier and the Jetoula ridge, above the Pavillon du Mont Fréty, north of Entrèves, documented by unpublished internal reports (Fig. 9A) and concluded with a monograph (BAGGIO, 1958). This paper began with a critical examination of the geological literature on the southern flank of Mont Blanc, later integrated by the monograph by Maria Bianca CITA (1953) on the stratigraphy of the Val Ferret and the fan-shaped structure of the massif, and with some notes by Rudolf TrüMPY (1951, 1952) and Giulio Elter (1953, 1954, 1955). Baggio's monograph continued with a description of the geological, petrographic and geochemical features of the main lithology: various types of granite, enallogenic inclusions, differentiated felsic aplite, quartz dykes and Alpine hydrothermal products. Particular attention was paid to the macro- and microscopic examination of the cataclasite, mylonite and blastomylonite of the granite and to their uranium mineralisations, discovered together with 

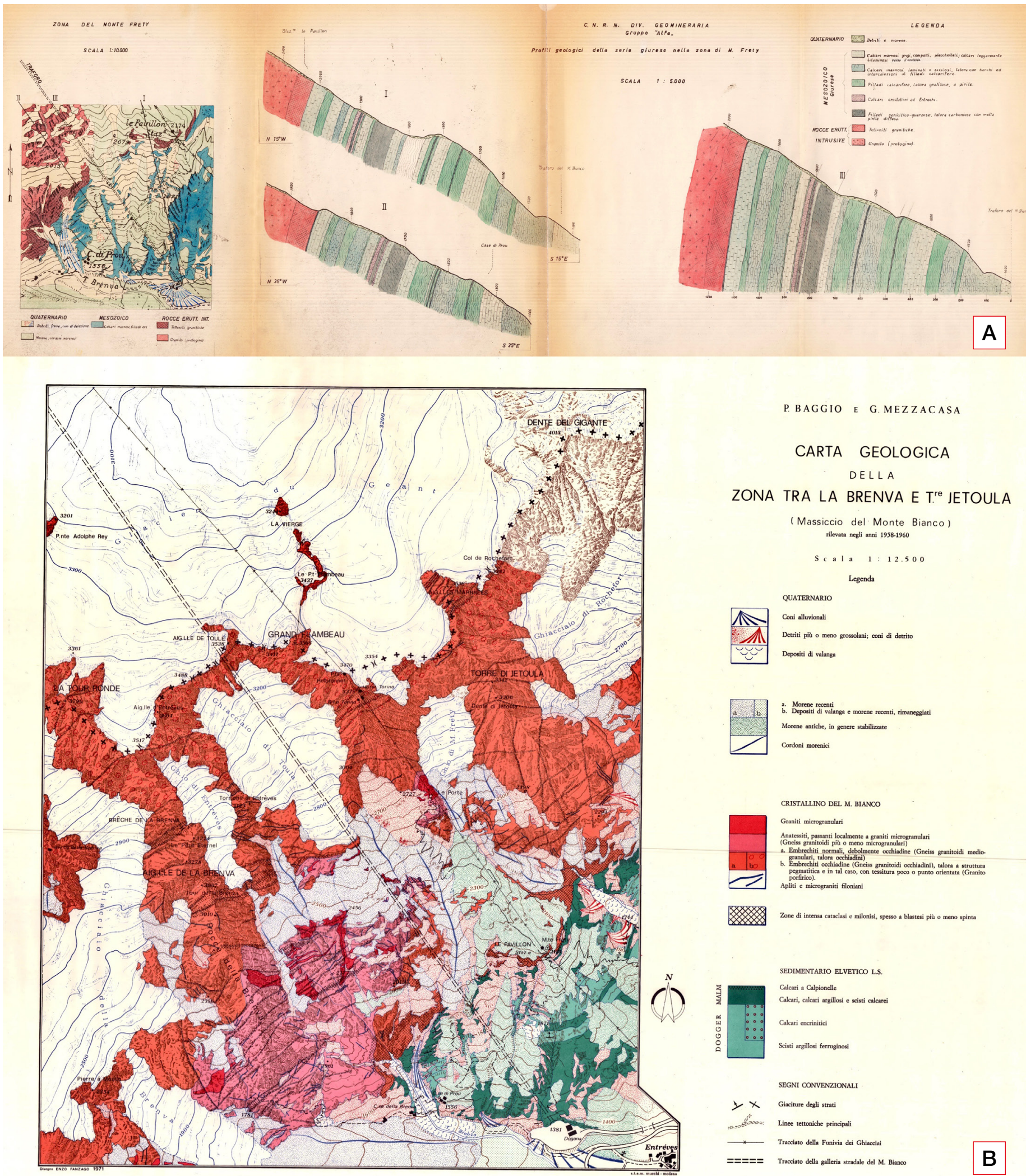

Fig. 9 - (A) Hand drawn geological map of Mont Frety area and profiles I-II-III across the Jurassic series: Divisione Geomineraria, Gruppo Alfa, CNRN, June $20^{\text {th }}$, 1959. (B) Geological map of Brenva-Torre di Jetoula zone, 1:12,500 scale, Italian side of Mont Blanc, BAGGIo \& MEZZACASA, 1971, field survey for radioactive mineral research, 1958-1960. 
the prospectors of Baggio's team. Fig. 9B shows a geological map of the area and related sections, drawn by hand (Divisione Geomineraria, 1959, unpublished), followed by an upgraded edition of the map, signed by BAGGIO \& Mezzacasa (1971), who had carried out the prospection; the track of the tunnel is marked in both maps.

When the Mont Blanc tunnel project was finally about to become reality, the Committee for Geology, Geography and Mineralogy of Italy's national committee for research (CNR), under the auspices of the Accademia Nazionale dei Lincei and promoted by A. Bianchi and Gb. Dal Piaz, had financed a "Programme of Studies on the Tunnel", and had charged the Institute of Geology of the University of Turin (director Roberto Malaroda) and the Laboratory of the CNRN, later CNEN, of Turin (director Paolo Baggio), with the consent of Felice Ippolito, to carry it out.

\section{GEOLOGICAL SURVEY OF THE ITALIAN SIDE OF THE MONT BLANC TUNNEL DURING EXCAVATION}

The mapping, geological and structural research and systematic sampling along the entire Italian tract of the tunnel were carried out by Giuseppe "Gè" Mezzacasa (a mining expert from Agordo school) who he had been transferred from Turin to Courmayeur in order to carry out daily observations of the progress of the excavations, from the beginning of works (January $8^{\text {th }}, 1959$ ) until their conclusion (August 14 $4^{\text {th }}, 1962$ ). This work was carried out under the supervision of Paolo Baggio, Mezzacasa's director of the Gruppo Alfa of the CNRN and then of the $\mathrm{CNR}$, with the collaboration of Gioria (topography), Olivero (temperature measurements) and Caretta (chemistry and physics of waters); optical microscopic study of the samples was carried out by Malaroda in collaboration with Baggio.

The Regional Museum of Natural Sciences of Piedmont, which contains the previous collection of rocks from Fréjus and San Gottardo, has many materials from the Mont Blanc tunnel, initially conserved in Palazzo Carignano, the Museum of Geology and Paleontology of the University of Turin (GAllo, 2004, 2008). They include: i) 538 samples from the tunnel; ii) a collection of photographs of rocks, textures and structures; iii) original datasets, schemes and drawings, scale 1:500, of the geological and structural fieldwork on tunnel samples; iv) thin sections prepared by Armando Coeli and used by Malaroda for optical microscopic study; v) a geological 3D drywall model of the massif (kindly noted by Annalaura Pistarino).

The main results of research, both along the Italian tract of the tunnel $(5,800 \mathrm{~m})$ and in the laboratory, are described in six notes of the Rendiconti Lincei (BAGGIO et alii, 1960; BagGio \& MALARODA, 1961, 1962, 1963, 1964a, 1964b). They show the five progressive states of advance of drilling-represented as a planimetric graph of the vault and sides of the tunnel, in black and white (first note) and in colour (the others) (Fig. 10A and 10B), in which (translation) 'the essential characteristics of the series of terrains are shown, together with their structural setting and the most important areas of cataclastic and mylonitic deformations, including the location and extent of the main flows of water'. It summarises the main data appearing both in the reports which the Divisione Geomineraria of the CNRN had produced, following day by day the advance of the tunnel, and in the diagrams which the same Division made available to technical staff working on the project (BAGGIO et alii, 1960).

Mezzacasa is not mentioned among the authors of these notes, but in those days technical personnel were rarely involved in scientific publications - even when, as in this case, they were dealing with a long and truly exceptional work involving high quality and active participation by personnel. Mezzacasa's contribution is only quoted in footnotes: we report here that of the final article by BAGGIO \& Malaroda (1964b), in which they mention that (translated) 'the collection of data and on-site samples, and photographic documentation, were carried out with intelligent expertise and diligent interest by the mining expert $G$. Mezzacasa, then working for the CNR'. It should be noted that the 'collection of data' included daily geological surveys, data sheets and tables, and drawing of the planimetric geo-structural graphs of the vault and sides of the tunnel.

The research project encountered problems when, in 1962, the Divisione Geomineraria was closed down, due to problems imputed to its management - an event which risked compromising the end of all studies on the Mont Blanc massif. This problem was overcome in 1963, with the passage to the CNR (mainly thanks to Angelo Bianchi) of Baggio, Mezzacasa and other members of personnel of the Alfa Group within the new Study Centre for Geology and Petrology of the Alps, Padua section (DAL PIAZ, 2018). Work on the data and material collected continued at the University of Turin and the CNR laboratories in Padua, and ended with the publication of the above-mentioned notes, followed by a conclusive monography by BAGGIO (1964), which also reported the preliminary results of new radiometric datings (BAGGIO et alii, 1967). These publications may easily be consulted and we therefore believe that it is sufficient to comment on graphs and the main novelties, together with the interpretation proposed for the genesis and evolution of the crystalline basement inspired by the doctrine of 'metasomatic granitisation' of Jung \& Rocoues (1952). Applied by Malaroda \& Schiavinato (1958) to the massif of Argentera, it was now extended to the granite of Mont Blanc: the protogine of Jurine (1806) became a metasomatic embrechite, and returned to being the intrusive granite of modern authors, or its derivatives - with feeble to pervasive mineralogical and structural transformations, imputable to the extensional PermoMesozoic tectonics and the Alpine orogenesis.

The six notes of the Rendiconti Lincei are mentioned in the following five sections, the first devoted to the initial part of the tunnel, almost entirely excavated in the Mesozoic successions of the Helvetic Zone, and the other four to later excavations, all in the granitic basement of Mont Blanc, with references to the planimetric graphs.

\section{FIRST TRACT: THE MESOZOIC SUCCESSIONS FROM THE ITALIAN ENTRANCE TO $1300 \mathrm{M}$}

Excavations in the tunnel began on January $8^{\text {th }}, 1959$ and reached 1304,30 metres on December $14^{\text {th }}, 1959$. This first tract is described in the note by BAGGIO et alii (1960) and appears in the litho-stratigraphic and structural graph of Fig. 10A. It shows a succession of Mesozoic sediments, as follows: i) cherty limestone with rows of sericitic quartzite and local interbedding of clayeysericitic limestone and some phyllites (Lower CretaceousLate Malm?); ii) clayey-sericitic limestone and calcareous 


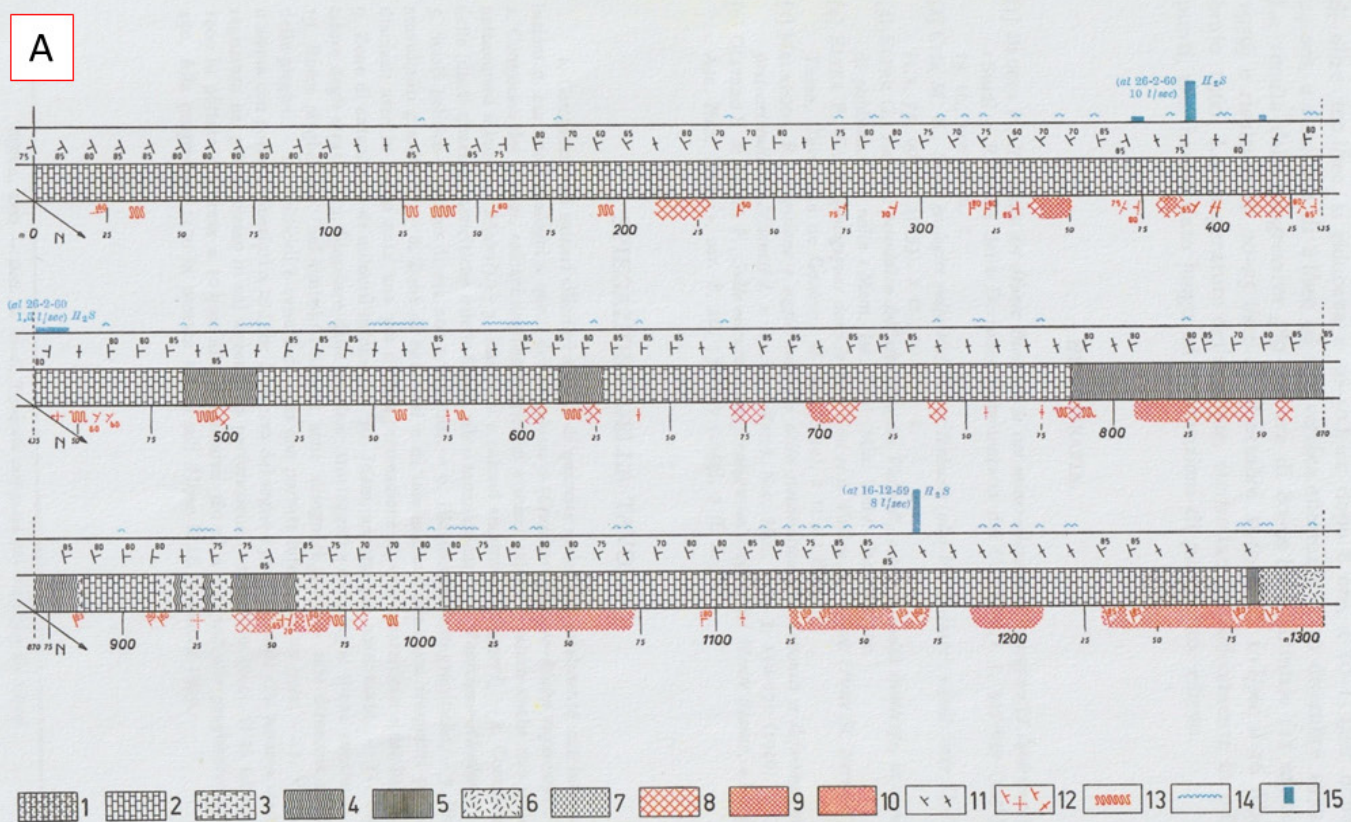

\section{B}
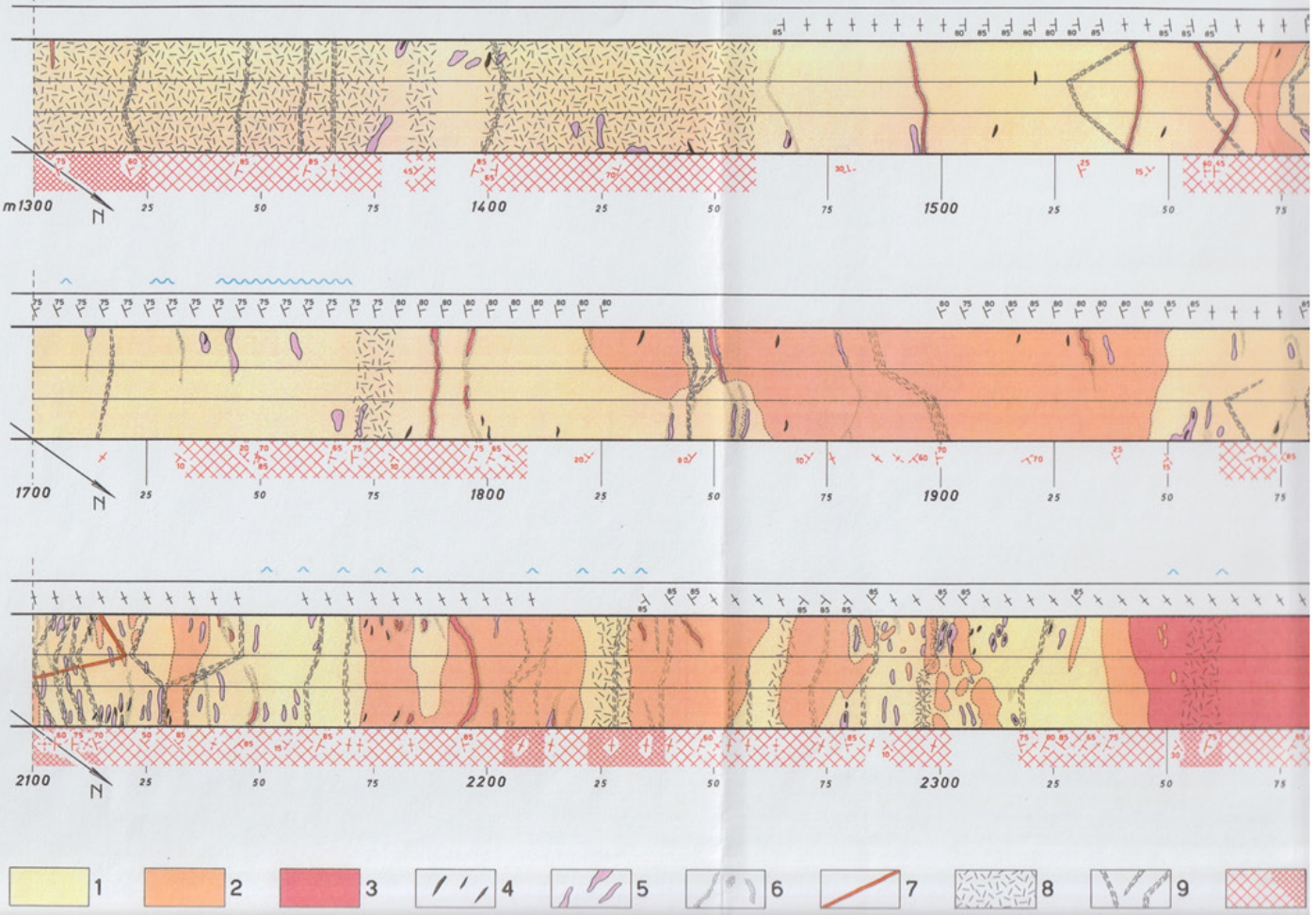

Fig. 10 - Geological graphs of the vault and sides of the first two of progressive advances of Mont Blanc tunnelling, Italian side, surveyed by Mezzacasa and described by BAGgio et alii (1960) and BAGGIO \& MaLARoda (1961). (A) First tract: 0-1,300 m, Legend: 1-5) Lower Cretaceous-Dogger (?) sedimentary succession, 0-1,281.25 m, see text; basement rocks: 6) blastocataclastic granite; 7) blastomylonitic granite; 8) cataclastic and shear zones, often impregnated by quartz and calcite veins; 9) severe cataclastic-mylonitic zone; 10) idem, most pervasive; 11-12) bed and diaclase attitude; 13) folded rocks; 14) dripping and infiltrations less than $10 \mathrm{l} / \mathrm{sec}$; 15) watershoots exceeding 10 litres/sec, and a bar showing the median flow measured on the same day as drilling $(1 \mathrm{~mm}=10 \mathrm{l} /$ sec). (B) Second tract: 1,300-2,500 m, Legend: 1) normal protogine and augen embrechites; 2) aplitisation facies of protogine; 3) microgranular aplitic granite; 4) relics of biotitic gneiss (septa); 5) feldspathisation patches and swarms; 6) late biotitic swarms of feldspathisation zones, mainly discordant to protogine foliation; 7) dykes of microgranular leucocratic granite and aplite; 8) cataclasites and blastocataclasites; 9) mylonites and blastomylonites; 10-11) red ornaments: impregnation of quartz veins with weak, medium to strong intensity; 12-13) structural measures; 14) dripping and infiltrations less than $10 \mathrm{l} / \mathrm{sec}$. 
schists, sometimes with phyllitic facies (Malm?); iii) encrinite and encrinitic limestone (Dogger?); iv) quartzsericitic \pm calcariferous phyllite (Toarcian-Aalenian?); v) pelitic-arenaceous schists (doubtful age). The succession extends from the entrance near Entreves, to 1281,25 m under the southern flank of the Pavillon du Mont Fréty, referred to the undifferentiated Helvetic cover units, in tectonic contact with the granitic basement (CITA, 1953; OulianofF \& TRumpY, 1958; Baggio, 1958; Compagnoni et alii, 1964; Elter \& Elter, 1965). Recently mapped (CARG Sheet n. 68 Monte Bianco, scale 1:50,000, in progress), the Mesozoic succession has been attributed (L. Passeri, personal comment) to the Pavillon-Col Ferret unit, composed of black siliceous schists (comparable with the Dugny Formation of the Helvetic cover nappes, Aalenian), dark limestone, sometimes encrinitic (Bajocian), grey marl and ferruginous shale (Schilt Formation, Oxfordian) and grey-bluish crystalline limestone (Quinten formation, Oxfordian-Tithonian), according to BURRI \& MARRO (1993). Their attitude, measured every $10 \mathrm{~m}$ (mean values), were recorded daily and are shown in the graph: they vary from vertical to strongly dipping towards the inner part of the mountain (north-west), except for the first 160 metres, where they dip outwards, due to gravitational collapse. There are frequent cataclastic and mylonitic bands, mainly in the segments at 800-850 and 1000-1300 m, sometimes accompanied by impregnation of hydro-thermal veins of quartz and calcite.

In the last 23 metres of this first tract, starting from $1281.25 \mathrm{~m}$ (Fig. 10A), the tunnel leaves the Mesozoic successions and penetrates the border shear zone of the crystalline basement, characterised by intense cataclastic and mylonitic deformations. Protoliths, identifiable mainly under the microscope, are medium-grain granite and microgranular aplitic varieties, also shown in Foglio 27 (Monte Bianco) of the Carta Geologica del Regno d'Italia, scale 1:100,000 (Franchi 1901; Franchi \& STELla, 1912; StELla, 1927, Fig. 8B).

Excavations did not present particular difficulties, thanks to the nature of the rocks and the favourable orientation of the tunnel with respect to the stratification. The main problems were two infiltrations of water under pressure and local collapse of material from the vault, due to intercalations of mylonitised phyllite and rock-burst in a tract of very compact cherty limestone (BAGGIO et alii, 1960; ZignOLI, 1965).

THE CRYSTALLINE BASEMENT TO 5800 M AND THE ORIGIN OF PROTOGINE

The second tract of the tunnel is described in the first of five notes by BAGGIO \& MALARODA (1961) and is included between 1,304.30 (December 14 $4^{\text {th }}, 1959$ ) and $2503 \mathrm{~m}$, reached on January $3^{\text {rd }}, 1961$. The third tract, described in the second and third notes of BagGIO \& Malaroda (1962, 1963), reached 3,701 $\mathrm{m}$ (December 31 $\left.{ }^{\text {st }}, 1961\right)$; the fourth tract (BAGGIO \& MALARODA, 1964a) reached 4,900 m (May 26 $6^{\text {th }}, 1962$ ), with half-section excavation, and then a complete section (October 29 ${ }^{\text {th }}, 1962$ ); the fifth and last tract (BagGio \& Malaroda, 1964b) reached the end of the Italian sector of the tunnel $\left(5,800 \mathrm{~m}\right.$, August $\left.3^{\text {rd }}, 1962\right)$ : this is the last report of the Gruppo di Ricerca sul Traforo del Monte Bianco, with which Baggio and Malaroda concluded their geological description of the tunnel, including a comment on the fifth graph which, like the preceding ones, shows the usual structural and hydrological data in the margin.

In the second tract (Fig. 10B; BAGGIO \& MALARODA, 1961) protogine prevails, i.e., a coarse-grain granite, with large crystals of potassic feldspar, idiomorphic or lenticulated, with more or less evident oriented texture, marked by biotite flakes. Unoriented granitic facies are quite common, assigned by the authors to phenomena of 'late aplitisation, with essentially quartz supply', and the original prevalence of sialic components. The protogine passes to microgranular aplitic granite 'due to gradual reabsorption' of biotite and potassic feldspar. Throughout the protogine facies there are concordant and discordant examples of 'feldspathisation' and frequent biotite swarms.

The third, fourth and fifth tracts are shown in the corresponding color graphs (BAGGIO \& MaLAROdA, 1962, 1964 a-b), very similar to the previous one, with complementary petrographic descriptions (BAGGIO \& Malaroda, 1963) which reveal the more explicit influence of the metasomatic doctrine of Joung and Rocques.

The more or less gneissic granite (magmatic and/ or metamorphic foliation) becomes typical 'augen embrechites', magmatic phenocrystals of potassic feldspar become 'more or less idiomorphic porphyroblasts' and aplitic granites become 'anatexites'; the schistosity is marked by the parallel orientation of feldspar and biotitic layers. The graphs distinguish both the main 'facies and small veins of feldspathisation, with potassic feldspar concentrated in phenoblasts with idiomorphic tendency, biotite swarms deriving from late mobilisation, often associated with zones of granitisation, and pegmatoid embrechite', only slightly foliated or not at all, more frequent in the French tract.

The origin of the embrechite (protogine) is attributed to the metasomatic transformation of ancient biotiteplagioclase-rich gneiss, documented by relict nuclei of microgranular biotitic gneiss (septa), round, elliptic or lenticular in shape, and generally of $\mathrm{cm}-\mathrm{dm}$ size, rarely reaching one metre. The granitisation of the biotiteplagioclase gneiss (paleosome) is imputed to 'ancient potassic metasomatism, accompanied by addition of quartz', which transformed it into augen embrechite. This gradually passes to true coarse-grain augen granite, due to the progressive increase of feldspar phenoblasts (in fact, the igneous porphyric granite is transformed into various grades of foliated and more or less gneissic facies).

A peculiar feature is the final enrichment of quartz in typical granoblastic aggregates and, when this becomes substantial, the rock seems to be 'clearly aplitised, i.e., it passes to types of protogine in the process of aplitisation and microgranular aplitic granite'. Late biotite tends to migrate towards the rim of the aplitised bodies and should therefore be Alpine: this is confirmed by preliminary radiometric datings of neogenic biotite, carried out in the Laboratory of Nuclear Geology of the University of Pisa, directed by Giorgio Ferrara, with Rb/Sr ages between 20 and $30 \mathrm{Ma}$ (Baggio \& Malaroda, 1964 b).

As already noted, the graphs show various planar anisotropies, systematically measured along the tunnel (joints, faults, stratification, schistosity of embrechite, cataclasite and mylonite), confirming the fan-shaped structure of the crystalline basement, trending N20EN70E, and a central subvertical sector in the third tract. All the rocks are more or less deformed, with extensive zones characterised by typical mylonite and cataclasite, 
partly recrystallised (blasto-cataclasite). The graphs show through appropriate ornaments the 'zones of cataclasis, extensive lamination and joints, of weak, medium to strong intensity' - areas which contain frequent refills of chlorite and epidote and encrustations of limpid zeolite (stilbite), rosettes of calcite and impregnations of haematite, which make the cataclastic feldspar pink or red.

During the advance of the tunnel, improvised brittle breaking of the rock occurred (tension blows, rock-burst), due to elastic decompression of the rocky mass generated by excavation. These events mainly took place in the vault and its junction at the sides, chiefly in relatively massive rocks: 'the fallen blocks are flakes and plates, sometimes concoidal, less frequently flattened masses', generally in the excavation front. Metal nets fixed with expansion bolts were effective in preventing or containing these dangerous damaged zones.

\section{The SECOND MONOGRaPH OF PAOLO Baggio}

Once the tunnel had been completed, in 1964 Baggio published his monograph 'Contribution to geological knowledge of the Italian flank of Mont Blanc', integrating and summing up his previous surface research in the area between the Brenva glacier and Torre di Jetula (BAGGIO, 1958; BAGgio \& Mezzacasa, 1971; field work carried out in 195960) and later notes, written with Malaroda, on the Mont Blanc tunnel. It also contains an interesting 'Tectonic map of the Italian side of Mont Blanc', scale 1:25,000, extending from the Pyramides Calcaires (Val Veny) to the head of Val Ferret (Fig. 11, drawing by G. Mezzacasa, 1964).

The monograph describes the paraschists and their contact with the granitic nucleus along the left flank of the high Val Veny: paragneiss and felsic migmatite, mapped as 'crystalline pre-Carboniferous schists' in the Mont Blanc and Aosta sheets (1912) of the Geological Map of Italy as the probable southern extension of the Goûter Complex defined by Corbin \& Oulianoff (1924) on the French side. Similar lithotypes were reported for the first time in the Dames Anglaises (Peuterey ridge) and the summit of the Aiguille du Châtelet, south of the Monzino hut. Baggio confirmed the intrusive character of the contact between granite and schists, exposed on both sides of the Brouillard glacier: the contact is clear-cut, without the typical cornubianite or intrusive breccias found elsewhere, and is marked by a thin aplitic band. The granite is a coarse-grain and medium-grain facies: further from the contact it becomes enriched in increasingly frequent phenocrystals of potassic feldspar, passing to non-oriented pegmatoids (southern base of the Aiguille du Châtelet) or the 'migmatitic facies of the augen embrechite'. The more evident 'migmatites in embrechitic facies' (gneiss oeillé of Duparc and Mrazec) are widespread between the Colle del Gigante and the Brenva glacier; bodies of microgranular aplitic granite are located mainly in the southern border of the intrusive nucleus (e.g., Prè de Bar).

In conclusion, and confirming the choice to use the geologic-petrographic terminology of Joung and Rocques, the author repeats: 'the presence of true migmatites (embrechites and anatexites) within the large gneissic zones of the intrusive core and their evolution towards normal granite through transition facies cannot be denied'.

Resuming the main results of structural research on the Italian flank of Mont Blanc, Baggio mentions the substantial parallelism of the Hercynian and Alpine tectonic trends and the pre-Carboniferous age of the former, sealed by the discordant black sandstone of Miage, with Upper Carboniferous flora (FRANCHI, 1901). They are represented by a series of sub-parallel tectonic lines trending NE-SW, composed of alternations of vertical or sub-vertical mylonite, with a NW dip. Due to scale limitations, only these most important tectonic lines are shown in the attached tectonic map (Fig. 11).

Colle del Gigante-Dames Anglaises-Brouillard tectonic line - This line can be followed with continuity across the Rifugio Torino, Brêche della Brenva, Colle dell'Innominata and the glacial basin of Miage. Its eastern extension is difficult to document, due to the local terrain, but it 'seems to find further continuation on the southern flank of the

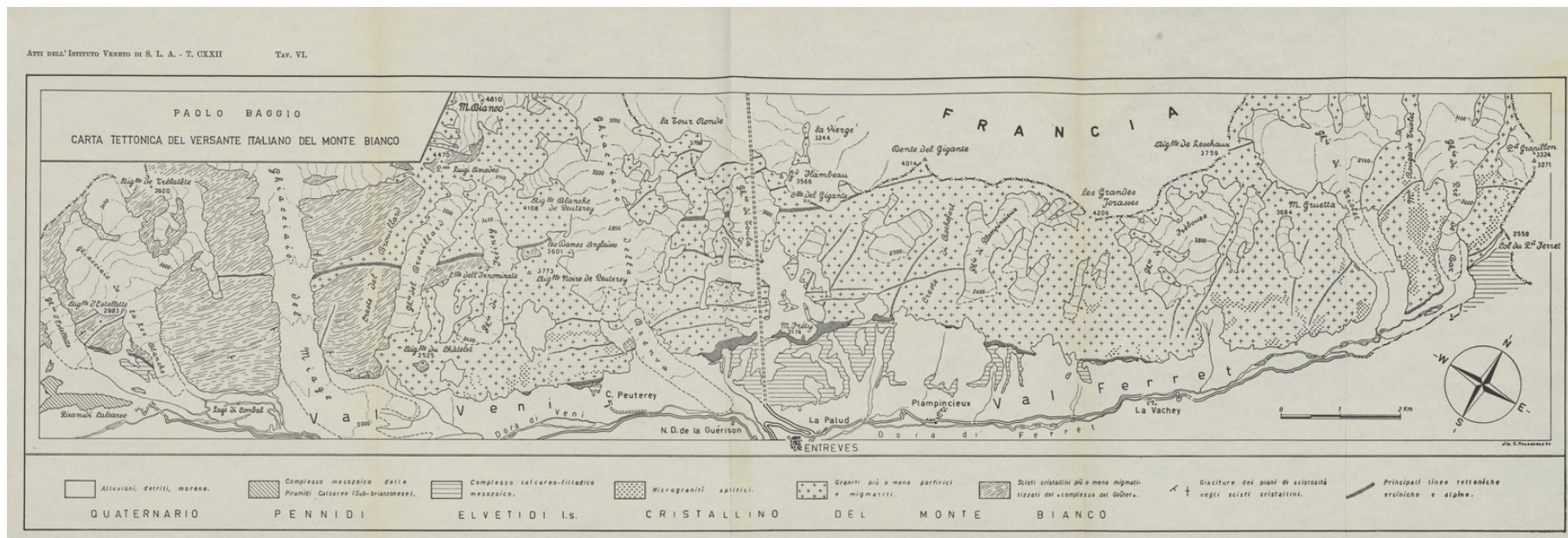

Fig. 11 - Tectonic map of the Italian side of Mont Blanc, scale 1:25,000, extending from the Pyramides Calcaires (Val Veny) to the head of Val Ferret (BAGGIO, 1964; drawing G. Mezzacasa). 
Dente del Gigante' (confirmed, DaL PIAZ, unpublished data, 1963). At the opposite extremity, between the Picco Luigi Amedeo and the Creste del Brouillard, the line dislocates the intrusive contact between the capping crystalline schists of the Goûter complex and the granite of the intrusive nucleus, with a normal displacement of about $1000 \mathrm{~m}$.

Petit Ferret-Mont Frety-Estellette tectonic line Already partly reported (CITA, 1953; BAGGIO, 1958), this line marks the tectonic contact between the crystalline basement of Mont Blanc and the Mesozoic sediments of the Helvetic zone along the Ferret and Veny valleys. It is characterised by cataclasite and a mix of limestone and minor granite slices, visible at the Col Petit Ferret, La Vachey, and under the southern walls of the Aiguille d'Estellette. Its maximum thickness is 120 metres, estimated at Mont Fréty, where 'the Mesozoic terrains clearly plunge under the rocks of the intrusive nucleus'.

The progressive exhumation of Mont Blanc took place 'in a prevalently vertical or subvertical trend, due to a subdivision of the masses into blocks, slices and large listric wedges', bounded by extensive mylonitic and cataclastic shear zones. The preliminary radiometric ages of Alpine biotite (BAGgio \& Malaroda, 1964b) indicate that the rise of Mont Blanc is 'the expression of a single tectonic Alpine phase, corresponding to the Miocene or, more probably, the Oligocene-Miocene', without excluding 'more recent Alpine movements', represented by faults and sandy-clayey fault rocks.

\section{Rb/Sr Age determinations of Samples from the Mont Blanc TUNNEL}

Radiometric dating by Giorgio Ferrara in the Laboratory of Nuclear Geology of the University of Pisa on samples collected in the Italian part of the tunnel were published in a paper by BAGGIO et alii (1967). According to the authors' aims, it was to be the first contribution of a more extensive programme on the problem of the age of Mont Blanc, but, unfortunately, it remained a dream. As regards petrogenetic problems, the paper confirms the importance of metasomatism as the basic cause of polyphase granitisation: 'embrechite, anatexite and granite represent progressive granitisation through a whole series of intermediate facies', according to BAGGIO \& MALARODA (1961, 1962, 1963, 1964a, 1964b) and BAGGIO (1964).

To reassume: i) the so-called granite of the Italian flank of Mont Blanc is a 'migmatite of augen embrechite type'; ii) it gradually passes to pegmatoid augen embrechite and porphyric granite, a local non-foliated variety, sometimes with high contents of quartz; iii) all these rocks contain 'porphyroblasts' of potassic feldspar (pertitic microcline), the result of 'potassic metasomatism', which transformed a series of biotitic gneiss, of which only small relicts (septa) remain; iv) the metasomatic process was accompanied in its final phases and/or followed by cataclastic and mylonitic deformations; v) late mobilisation of biotite, accompanied by quartz and sometimes albite, are responsible for the formation of 'fine-grain anatexite and small patches of aplitic microgranite'.

In conclusion, the granitisation of the Mont Blanc massif is due to two metasomatic phases, separated by a deformation event: 1) potassic metasomatism of the original biotitic gneiss: formation of augen embrechite and augen-anatectic embrechite and, more rarely, porphyric granite, characterised by large microcline porphyroblasts; 2 ) cataclastic and mylonitic deformations, with ovalisation and crushing of the microcline porphyroblasts; 3) quartzalbite metasomatism with mobilisation of neogenic biotite, sometimes accompanied or immediately preceded by intense cataclastic and mylonitic deformation (blastocataclasite and blasto-mylonite; see BAGgIo \& MaLAROdA, 1961). The fine-grain anatexite and aplitic microgranite are the result of this mobilisation.

Sixteen samples were collected in the tunnel (see graphs for location): 7 embrechites of various types, 3 anatexites, 2 aplitic microgranites, 2 biotite-plagioclase gneisses (septa), and two swarms of neogenic biotite. $\mathrm{Rb} /$ Sr dating on whole rock and biotite was carried out: 14 whole-rock isochrons supplied an age of $263 \mathrm{Ma}$; once the septa (pre-metasomatic relics) had been removed, a value of 313 Ma was obtained and interpreted as the 'primary age' of the metasomatic rocks (i.e., the protogine). However, the age of the biotite is Alpine, between 36 and $18 \mathrm{Ma}$, and dispersion of values may be attributed to a mixture of Hercynian biotite ( \pm chloritised) and Alpine biotite, the latter responsible for the lower values.

\section{TUNNELLING, SPRINGS AND THERMAL REGIME}

To complete this history of work and studies on the Italian part of the Mont Blanc tunnel, we report here some notes on the progression of the excavation, taken entirely by ZIGNOLI (1965), on the main springs, taken from graphs, of water chemistry (CARETTA, 1967) and the temperature of the rock mass (PENTA \& Olivero; 1959; Olivero, 1962).

The five graphs described by Baggio and Malaroda synthetise the geological work carried out while the tunnel was being built and represent (in red) cataclastic zones and (in blue) hydric data, i.e., i) dripping and infiltrations less than $10 \mathrm{l} / \mathrm{sec}$ (wavy line); ii) watershoots exceeding 10 $\mathrm{l} / \mathrm{sec}$, and a bar showing the median flow measured on the same day as drilling $(1 \mathrm{~mm}=10 \mathrm{l} / \mathrm{sec})$.

\section{DRILLING PROGRESS}

The tunnel was excavated with a series of compressed air drills installed on a Jumbo boring machine, which could work on two or three mines per day, or with appropriate techniques in cases of half-section drilling or in cuniculi; mining debris was removed by truck. 'At first, advance seemed to be easy', at a speed of 8-10 metres/day, up to three mines of 4 metres each (ZIGNOLI, 1965). It was at this point that difficulties began: at 368,20 $\mathrm{m}$ from the entrance (February $\left.20^{\text {th }}, 1959\right)$ water jets pressurised at $350 \mathrm{l} / \mathrm{sec}$ invaded the tunnel, falling to $10 \mathrm{l} / \mathrm{sec}$ on February 26 (BAGGIO et alii, 1960; graph I). A few weeks later (501 m, April $\left.4^{\text {th }}, 1959\right)$, an intercalation of carbonaceous phyllite caused a chimney to open in the vault and it collapsed, burying the Jumbo: the damaged area involved about $100 \mathrm{~m}$ of the tunnel, and 100 days were necessary before it could be crossed, first with a cuniculus and then in half-section. At $809 \mathrm{~m}$ (August $12^{\text {th }}$, 1959) a second collapsed section of $50 \mathrm{~m}$ appeared and was only crossed 59 days later.

On December $15^{\text {th }}, 1959$, at $1,304 \mathrm{~m}$, 'the first strata of protogine were reached - the so greatly desired granite of Mont 
Blanc'. At this point, 'believing that surprises were going to be less bitter', the workers returned to $501 \mathrm{~m}$, to enlarge the section of the tunnel and to facilitate the movements of mechanical vehicles. On April $11^{\text {th }}, 1960$, a second Jumbo was installed, weighing 40 tons, and digging was resumed in the granite. In the second tract of the tunnel $(1,300-$ 2,500 m; BAGGio \& Malaroda, 1961) only small drips were encountered, in spite of the spread of granitoids with more or less pervasive cataclasite, but immediately after unexpected 'rock falls occurred, that is, almost explosive detachments, due to elastic settlement of the drilled mass'. This situation required the vault to be armed with networks to sustain falling rocks, sometimes extending right to the drilling front. Excavations continued, with further difficulties until April 28 $8^{\text {th }}, 1960$ when, at 3,078.40 m, the workers encountered a 'completely decomposed granite, mylonitised and impregnated with water.' The progress of drilling became very slow: $240 \mathrm{~m}$ in less than five months, with vault collapses, at 3,130 and 3,230 m. More extensive in these zones, but also in others, a clayey-sandy material was found, repeatedly alternating with mylonite, 'the evident extreme product of grinding and alteration'. These were breccias and gouges of the deep extension of the cataclasite-mylonite shear zones mapped at the base of the Toules and Entreves glaciers (BAGGIO, 1964; BagGIO \& Mezzacasa, 1971; Guermani \& Pennacchioni, 1998).

Once the cataclastic zone had been passed, work continued more easily in the third tract, and in less than two months a further $250 \mathrm{~m}$ of tunnel had been drilled. However, on December $10^{\text {th }}, 1960$, at 3,665-3,670 m, a gigantic flow of water flooded the tunnel from a system of open fractures. It had been preceded by a significant fall in rock temperature, which had been measured a kilometre before, decreasing from $21-22^{\circ} \mathrm{C}(2520 \mathrm{~m})$ to a minimum of $13^{\circ} \mathrm{C}$ at $3,668 \mathrm{~m}$ - a particularly anomalous geothermal value, since the overlying rocky cover was about $2000 \mathrm{~m}$ thick (Baggio \& Malaroda, 1962, 1963). The initial flow approached $1000 \mathrm{l} / \mathrm{sec}$ (ZIGNOLI, 1965; $800 \mathrm{l} / \mathrm{sec}$ in BAGGiO \& Malaroda, 1962), and then stabilised at about $400 \mathrm{l} / \mathrm{sec}$ (April $\left.12^{\text {th }}, 1962\right)$ at a temperature of $11.4^{\circ} \mathrm{C}$, slightly lower than the initial value. However, flooding of the workplace and interruption of excavation did have the positive effect of lowering the environmental temperature, as it meant that planned work to cool the workplace during advance did not need be carried out, since the cold air ventilators to remove the explosive gases of the mine and the fumes of the diesel engines were sufficient. Drilling was resumed with difficulty, but then the rock mass gradually became easier, and in February 1961 advance in the entire section was possible for $246 \mathrm{~m}$, the highest speed achieved in the entire work, including the French part. A fractured zone at 4,109 $\mathrm{m}$ required local half-section advance.

Excavation of the fourth and fifth tracts (BAGGIO \& Malaroda, 1964a, 1964b) encountered the usual dripping and only flows from two small springs, $10.5 \mathrm{l} / \mathrm{sec}$ at 4,228 $\mathrm{m}$ and $18 \mathrm{l} / \mathrm{sec}$ at 4,840 m. On April 5 $5^{\text {th }}, 1961$, when drilling had reached 4,417 $\mathrm{m}$, three avalanches fell on the Brenva glacier, just missing the workplace, but the related flow of air caused the collapse of some huts, with three workmen killed and 30 wounded. When work resumed, the rock became 'less unpleasant', allowing peaks of $17.8 \mathrm{~m}$ per day, until 22.01 on August $3^{\text {rd }}$, 1961, when the centre $(5,800 \mathrm{~m})$ of the Mont Blanc tunnel was reached; on August $14^{\text {th }}$, the last diaphragm with the French part fell.

\section{Rock Temperature AND geOthermal GRADIENT}

In an earlier note, Olivero \& PENTA (1959) had described their programme for measuring rock temperature during excavation of the tunnel, i.e., the inferred thermal gradient, together with plans of difficulties to be overcome, bearing in mind procedures previously used during drilling Alpine tunnels (GIORDANO, 1871; ScHARDT, 1903a, 1903b; BIADEGO, 1906), but ignoring the thermal estimates by Kilian and Jacob in FRANCHI et alii (1908)

Tunnel research had been described by OLIVERo (1962) in the report 'First data on the temperatures of the subsoil during the excavation of Mont Blanc', presented by Penta at the Accademia dei Lincei. After having solved various difficulties, from lack of funds for the measurement stations (later obtained from the CNR) to evaluation of water flows, the aim of the programme was thought to be achieved, but was only limited to 'measurement of shallow mine holes'. Compatibly with drilling needs and geohydrologic conditions, the measurement stations were equipped, starting from $980 \mathrm{~m}$ from the entrance and at distances of 200-250 $\mathrm{m}$ from each other, then reduced beyond $3,000 \mathrm{~m}$, to follow temperature ranges which fell as excavation work progressed.

The measurements were carried out 'with scruple and dedication (...) by the mining expert Giuseppe Mezzacasa and the geometra Giorgio Gioria'. The results are given in the five graphs already mentioned and partly reproduced, and in a series of diagrams by Olivero (1962) in which, station by station, measurements of the rock temperature were shown as a function of time, together with the air temperature. Starting from the beginning of the granite, the rock temperature increased from $10-17^{\circ} \mathrm{C}$ to a maximum of $21-22^{\circ} \mathrm{C}$ in the next 2,300 and 2,500 $\mathrm{m}$ approximately, and then gradually fell to $13-14^{\circ} \mathrm{C}$ at $3,350 \mathrm{~m}$. The marked lowering of rock temperature in the Italian sector, not anticipated in detail, was explained by the diffusion of joints and cataclastic areas, although it was later determined as due to 'the influence of cold water of subglacial origin (confirmed by isotopic analysis of oxygen) and in particular at the large water flow at 3,668 $\mathrm{m}$, corresponding to the measured maximum fall in temperature' (Olivero, 1962; CARETTA, 1967). The report by Olivero (1962) is limited to temperatures measured in the second and third tracts of tunnelling and their assessment. The rock temperature measured in the two following tracts appear in the report of BAGGIO \& MALARODA (1962), who reported it in the Italian sector of the tunnel up to about $4,800 \mathrm{~m}$ : in this zone, after considerable thermal depression, the rock temperature gradually rose to about $26^{\circ} \mathrm{C}$. In the French sector, essentially dry, the temperature increased from the initial $12^{\circ}-13^{\circ}$ to the maximum of $30.8^{\circ} \mathrm{C}$, measured under the Aiguille du Midi $(3,778 \mathrm{~m})$, between 3,400 and $3,500 \mathrm{~m}$ from the French entrance (GUdEFIN \& VITEL, 1971).

\section{Water Characteristics}

The physical and chemical characteristics of the water in the Italian tract of the tunnel appear in a report by CARETTA (1967), with references to flow, temperature (from a minimum of $8.5^{\circ} \mathrm{C}$ at $3,665 \mathrm{~m}$ to a maximum of $26.5^{\circ} \mathrm{C}$ at $4,516 \mathrm{~m}$ ), radioactivity (not of particular importance), $\mathrm{pH}$ (average of many sources: April $5^{\text {th }}-6^{\text {th }}, 1963$ : 8.85; 
November $10^{\text {th }}-11^{\text {th }}, 1963: 8.82$; June $28^{\text {th }}-29^{\text {th }}, 1964$ : 8.13 ), fixed residue at $180^{\circ} \mathrm{C}$ (from 0.0460 to $0.2904 \mathrm{~g} / \mathrm{l}$ ), electric conductibility (matching fixed residue), organic substances (2.5-4.7 mg/l, much lower than 30-32, the maximum limit for good-quality drinking water). Water with the relatively highest mineralisation $(0.20-0.25 \mathrm{~g} / \mathrm{l})$ came from the first tract of the tunnel, with $\mathrm{pH}$ consistent with the abundance of carbonatic rocks. Ammonia and nitrites were absent.

Detailed geochemical research on stable isotopes $\left({ }^{18} \mathrm{O},{ }^{2} \mathrm{H},{ }^{34} \mathrm{~S}\right)$ was later carried out by Bortolami et alii (1979), FonTEs et alii (1979) and Zuppi \& BoRTolami (1982) on the groundwater of the tunnel, and showed that the Mont Blanc massif was an excellent natural laboratory for surveys of flows through fractured crystalline rocks and also crucial for evaluation of nuclear waste storage in hard rocks. Based on tritium distribution, BorTOLAMI $e t$ alii (1979) calculated a permeability of $5 \cdot 10^{-7} \mathrm{~m} \bullet \mathrm{s}^{-1}$ for the whole massif, and effective porosity close to $1 \%$, clearly due to the mainly vertical fracture systems.

\section{THE FRENCH SECTOR OF THE MONT BLANC TUNNEL}

On the French side, tunnelling began on May $30^{\text {th }}$, 1959, four months after the Italians, and was carried out by the well-known André Borie Company. At the request of Borie, since 1959 drilling had been supervised by a permanent team of geologists from the BRGM who were asked to 'supply information on the composition and technical characteristics of the rocks in the tunnel', to collect samples, prepare lithological collections and measure temperatures and radioactivity, for the High Commission of Atomic Energy (Guichonnet \& BERNIERI, 1963).

Geological studies had predicted that the contact between the complex of schists and the underlying granite would be found about 1,500 metres from the French entrance: in fact, it was at 3,200 m. Excavation in the schist did not present particular problems, but difficulties arose with the granite, due to frequent exfoliation and sudden fragmentation of the massive rocky mass, a problem which required the installation of containing nets anchored with 180,000 bolts. The advance of drilling was 7-9 $\mathrm{m}$ per day, and sometimes even $11 \mathrm{~m}$.

The survey during excavation of the French side of the tunnel was assigned to the engineer H. Gudefin, author of the unpublished report 'Etudes géologiques dans le tunnel sous le Mont Blanc (versant français) par le Bureau de recherches géologiques et minières (1959-1962)', summarised and developed by VITEL (1963), GUDEFIN (1967), GUDEFIN \& VITEL (1971) and BLÈS (1983). In particular, Gudefin made the graphic relief of the French side of the tunnel at scale 1:100, carried out continuously during the excavation - the so-called 'scientific film of the tunnel': this is reported by GUDEFIN \& VITEL (1971) The subject deserves deeper archival work, which we suggest to our colleagues of the Comité Francais d'Histoire de la Géologie.

The Borie company had data exclusivity for ten years, i.e., limiting its distribution, unlike the results of research in the Italian part - soon published, as we have seen, by the Accademia Nazionale dei Lincei. In October 1962, requested by the BRGM, a meeting at Chamonix had been organised to ascertain the geology of the tunnel, work on which had just been finished: French, Swiss and Italian specialists participated but, also in this case, no public information can be found. At the meeting, no basic innovations were presented on the geology of the Mont Blanc massif, apart from systematic observations along the tunnel (GuICHONNET, 1963). The main novelty in the French part was the presence, instead of the foreseen sharp contact between schists and granite, of a transition zone $400 \mathrm{~m}$ wide (Fig. 12), characterised by multiple imbrication of these lithotypes along a complex network of fractures (GudEFIN \& Vitel, 1971). Poor mineralisations of $\mathrm{Pb}-\mathrm{Zn}, \mathrm{Cu}$ and uraniferous minerals were found, similar to those detected on the surface of the Italian side (BAGGIO, 1958; FrANCESCHETTI, 1960); lacking, or sometimes kept by their finders, were the expected geodes of fine quartz, which have made the Mont Blanc granite famous.

\section{FROM GUDEFIN'S SURVEY TO VITEL'S THESIS}

The student George Vitel had been charged by the scientific office of the BRGM to describe the petrographic features of the 'série cristallophillienne et cristalline' along the French part of the Mont Blanc tunnel and to complete them with chemical analyses from the Centre de Recherches Pétrographiques et Géochimiques (CRPG) of Nancy. This study constituted the main part of his 1965 doctorate thesis ( $3^{\text {rd }}$ cycle), at the University of Grenoble. Vitel's research had begun in the summer of 1963, when most of the tunnel had already been covered by a concrete sheath, so that he was forced to carry out his fieldwork along the surface track of the French part of the tunnel between the Mer de Glace and Les Houches. Fieldwork was represented on the IGN topographic sheets, to the same scale of 1:20,000 as the geological maps of Duparc and Mrazec.

The lithological observations collected by Gudefin during the progression of drilling are reported by Vitel in a detailed data-sheet showing the rock types, their locations and a short description, mainly inferred from Gudefin's graphic relief of the gallery (GUDEFIN \& VITEL, 1971), (Fig. 13). From the French entry to 3,102 m (proceeding towards Italy) the tunnel drilled the 'série cristallophyllien', a pre-granitic complex of fine-grain quartz-feldspathic gneiss and micaschists, with repeated alternations of banded or chloritic gneiss, micaceous quartzite, sometimes associated with marble and carbonatic schists, amphibolite, augen gneiss, dykes of granite and aplite, cataclasite and mylonite, locally rich in pyrite. The succession is overturned north-west, above the Triassic formations of the Col de Balme. The so-called 'transition zone' (3,102-3,524 m) follows: as already noted at the Chamonix meeting, the contact between the 'série cristallophyllien' and the granite is a transition zone with often confused structures, due to an 'inextricable mélange of crystalline schists and granite' (Fig. 13). This then passes to granite, initially with inclusions of amphibolic schists and gneiss enriched with quartz and chloritic impregnations, and then to a massive 'pseudo-stratified' granite (due to decompression), granitised or amphibolic schists and granite $(3,473-3,524$ $\mathrm{m})$. These are followed to the middle of the tunnel $(5,800 \mathrm{~m})$ by the typical protogine: porphyroid granite with feldspar phenocrystals of $2-3 \mathrm{~cm}$, locally reaching $10 \mathrm{~cm}$, mediumgrain granular varieties, dark types with planar structure, and cataclastic to mylonitic facies. The 'strata' tip SE by $70^{\circ}-80^{\circ}$, indicating that this is still the external sector 


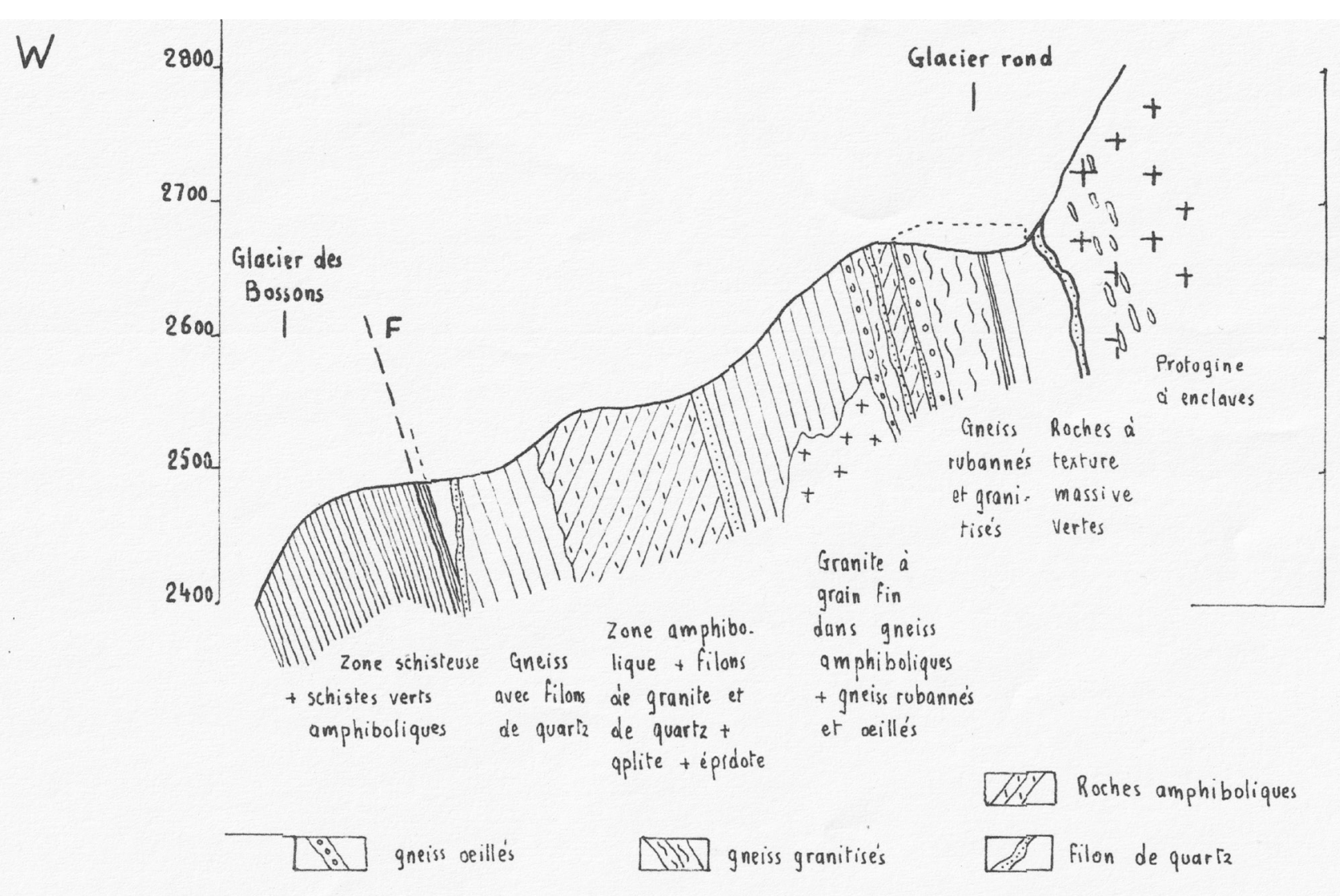

Fig. 12 - G. VITEL, Thèse (1965): geological section of the transition zone between the paraschist complex and protogine, French side.

of the 'eroded antiform' of the pioniers - today's fan. The granite is deformed by pervasive fracture systems: i) one, called 'classic' because of its frequency, trends N60-70E, subvertical to SE; it is cut by an orthogonal system which plunges NW and dislocates granitic dykes; ii) a network of subvertical joints, trending north-south and east-west, and cutting the main regional trends of the chain.

GUDEFIN \& VITEL (1971) also described the general conditions of the excavation works, focusing to the relationships between the geo-structural setting and the direction of tunnel, as well as the decompression rockbursts developed in the massive granite generally 2-3 days after the mine blasting.

The fracture systems shown in Gudefin's graphs are reported and reworked by BLÈs (1983), with particular attention to relations between small fractures and large faults, variations in the direction and density of fractures with depth, the effects on the rock mass of natural and artificial decompressions, and hydrological inferences. Soon after, a surface study of the fracture systems of the entire Mont Blanc massif was carried out by geologists from Florence (BERTINI et alii, 1985).

\section{Petrographic and geochemical study}

Vitel (1963) and Gudefin \& Vitel (1971) describe the petrographic, structural and geochemical features of a series of samples, probably collected by Gudefin's team. In particular, they distinguish the main lithological groups (crystalline schists and protogine), rock-forming minerals and their modal composition, and location along the tunnel.

The crystalline schists of the 'série cristallophyllien' are represented by: i) fine-grain gneiss (dominant facies); ii) sericitic gneiss, augen and banded gneiss, with quartzfeldspar layers alternating with micaceous films (frequent) and many accessory facies; iii) 'gneiss mouchetés', biotite gneiss, micaschists, sericitic and chloritic schists, quartzite, leptinite, amphibolite, and 'cipollino' marble. Of significance is the description in the paragneiss of relict porphyblasts of quartz-1 and fine-grain quartz-2 of dynamic recrystallisation or in cataclastic structures, albite-oligoclase porphyroblasts, generally altered, and evidence of two generations of biotite. Mylonite, phyllonite and pseudo-tachylite mark the shearzones and penetrative fracturing.

The whole-rock analysis (CRPG of Nancy) of four protogine samples is consistent with the composition of a monzonitic alkaline granite. Mineralogical associations: quartz, orthoclase, plagioclase (An 0-15) sometimes zoned, green biotite, chlorite, muscovite, sericite, epidote, with associated saussurite, myrmechite, perthite, micropegmatite; accessory components: titanite, ilmenite, leucoxene, calcite, apatite, rutile, garnet, pyrite, and calcopyrite. Two generations of quartz are described, one as fractured phenocrystals and the other as small elements with mosaic structure.

\section{Geological history}

The 'série cristallophyllien' is a monotonous crystalline complex of detrital origin, with intercalations of 
Tunnel sous le Mont-Blanc_ Coupe : de la zone de transition

\section{$:$ de la zone centrale du granite}
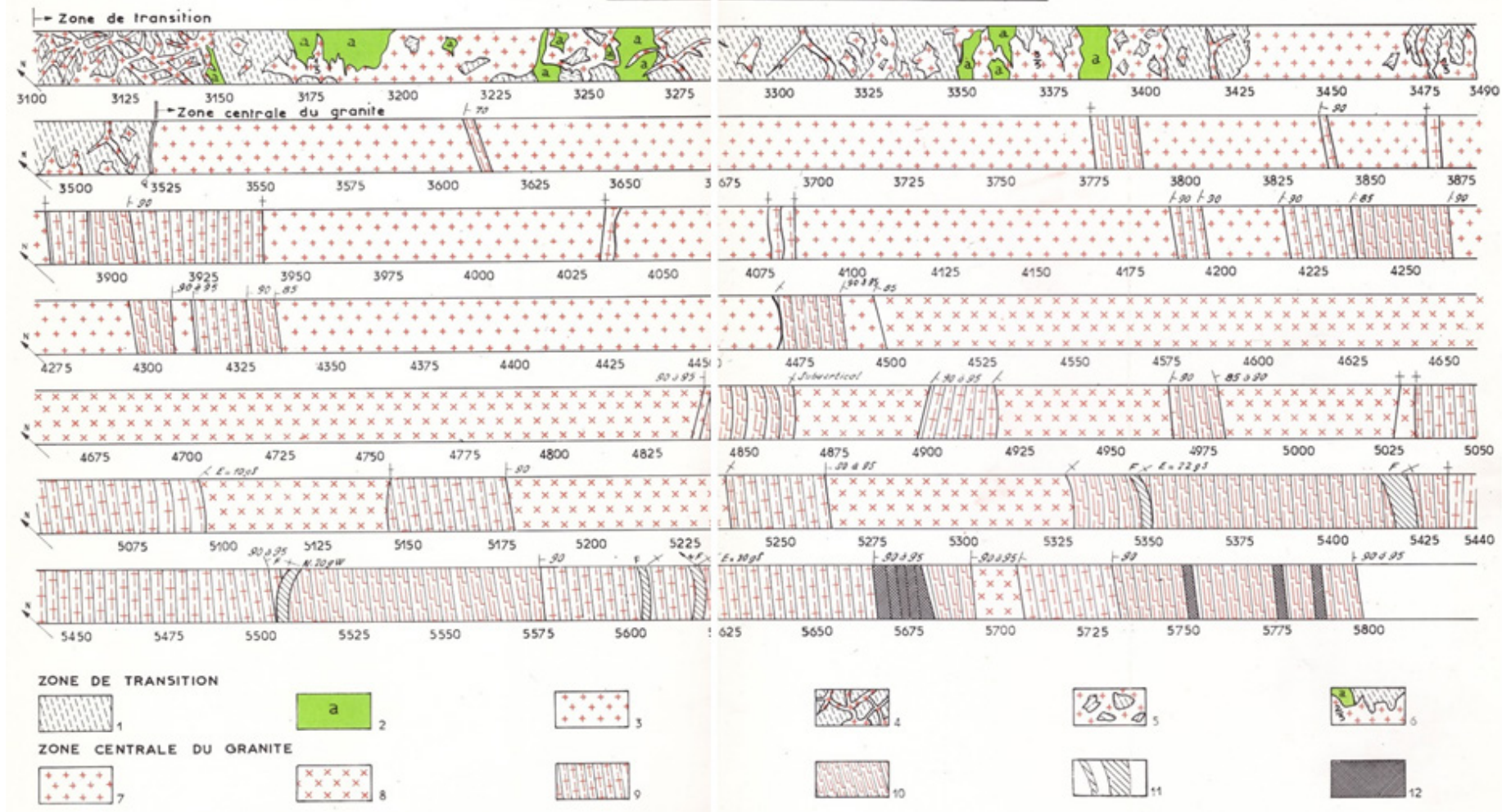

Caupe atoblic per H. GUDEFIN

SGR Jura-Alpes

Fig. 13 - Excerpt of geological graphs of the French side of the Mont Blanc tunnel, surveyed by Gudefin during excavation (low quality copy of the inedited report of GUDEFIN \& VITEL, 1971). Transition zone, 3,102-3,524 m from the French entrance: 1) phyllitic rocks; 2) massive amphibolite; 3) massive granite; 4) dykes and intrusive apophyses; 5) granite with relict nuclei of phyllitic rocks (intrusive breccia); 6) imbricated alternances of granite and metamorphic rocks. Granite central zone, 3,524-5,800 m: 7) granite; 8) porphyric granite; 9) foliated porphyroid granite; 10) sheared to mylonitic granite; 11) phyllonite; 12) friable altered mylonite; F) fault.

orthogneiss, amphibolite and old marble. It is characterised by amphibolite-facies regional metamorphism, preWestphalian in age, because it is absent in the overlying sandstone with Carboniferous flora: relics of biotite, muscovite, garnet and oligoclase are indicative of the 'zone des micaschistes inférieurs' (burial metamorphism). Two prealpine tectonic phases are evident, one trending NNO-SSE and NNE-SSO, and the other, also found in the Permo-Carboniferous layers, characterised by $\mathrm{N}-\mathrm{S}$ folds and attributed to Permian tectonics.

The granite emplacement, initially referred to the Caledonian orogenesis (Oulianoff, 1947), is of Late Carboniferous age, according to the whole-rock $\mathrm{Rb} /$ $\mathrm{Sr}$ isochron of BAGGIO et alii (1967). Vitel evaluates two petrogenetic hypotheses on the origin of the protogine and its relationships with tectonics: i) 'post-tectonic granite' of intrusive type (classic conception); ii) 'syntectonic granite' and 'metasomatic granitisation', the hypothesis preferred by Vittel, certainly influenced by Michel, one of his teachers. During the Alpine orogenesis, the crystalline basement underwent retrograde metamorphism, as shown by chloritisation of biotite, alterations of plagioclase, and the development of epizonal associations with sericite, albite, epidote, quartz, titanite and rutile. This was wellknown at that time in the Helvetic external massifs of Mont Blanc (Corbin \& Oulianoff, 1938), Aiguilles Rouges (BELlière, 1958) and Belledonne (Bordet, 1961); its Alpine age (41 Ma) was confirmed by $\mathrm{K}-\mathrm{Ar}$ isotopic dating by Krummenacher \& Evernden (1960). The late mobilisation of quartz and new biotite (BAGGIO \& MALARODA, 1964) was contemporaneous with the oligo-miocenic Alpine phases (BAGGIO et alii, 1967), a period during which Mont Blanc rapidly rose, accompanied by brittle deformations mainly due to oblique accretion of tectonic slices.

The main results of Vitel's thesis were taken up in the report by GUDEFIN \& VITEL (1971), also extending to the Chamonix syncline. It also notes that the Carboniferous successions cover the chronological interval from Westphalian-D to Stefanian-A, Late-Hercynian plutons are composed of both homogeneous and porphyric granite, and older paraschists also contain intercalations of metavulcanite. Two mineralogical associations are described: one (magmatic), with quartz, oligoclase, microcline-orthoclase, biotite and orthite, and another 
(recrystallised), with quartz-2, albite, perthite, biotite-2, epidote, chlorite and sericite.

\section{PETROGRAPHIC STUdY OF SAMPLES FROM THE FRENCH TRACT OF} THE TUNNEL

The historical collection of samples from the Mont Blanc tunnel, now in the Regional Museum of Natural Sciences in Turin, includes 366 samples, 194 from the Italian part and 172 from the French one: the former, probably collected by Mezzacasa, were given precise descriptions, with references to the notes of Baggio and Malaroda; the French ones only reported the sampling location. In order to fill this gap, the young museum curator L.M. Gallo had the excellent idea, together with Borghi and Porro, recent graduates, of providing the petrographic descriptions and creating a catalogue which lists 97 selected samples of granite and the older schists, all from the French part of the tunnel (BoRgHI et alii, 1987).

After an updated geological picture of the Mont Blanc massif, and a schematic profile along the axis of the tunnel, the paper described the main lithotypes of the French part and their evolutionary history. It also confirmed the existence of two 'key events', separated by the 'LateHercynian intrusion' of the granite and documented by particular metamorphic transformations: i) the preAlpine event, pre-Westphalian, to which the origin of the most important foliation was linked, was attributed to an early Hercynian phase; ii) the Alpine event, which was responsible for the partial low-grade metamorphic transformation of the intrusive granite and the final exhumation of the massif.

The representative samples of the pre-granitic (polymetamorphic) complex are 'paraderivatives, orthoderivatives of granitoid type, metabasites and granophyric porphyroids'. Among the paraderivatives, they are represented in order of decreasing abundance: fine-grain gneiss, micaschists, mylonitic schists and gneiss; augen gneiss with two micas and metagranite with associated dykes; among the metabasites: amphibolite, retrogressed facies and amphibolic gneiss with mylonitic structure. The mineral associations and microstructures of these groups are described in detail, from the relics of pregranitic metamorphism (garnet, biotite, muscovite, feldspar, plagioclase, quartz in schists and migmatites; diopside in carbonatic fels; potassic feldspar, plagioclase, biotite in augen gneiss), to the mono-metamorphic features of granophyres, mylonite and polyphase cataclasite, and greenschist-facies Alpine retrogression.

The samples of intrusive granite (protogine Auct.), indicated as metagranite, are characterised by two mineral associations: i) magmatic: composed of quartz, orthoclase with frequent pertite and myrmechite, zoned plagioclase, with more or less altered oligoclase-andesine core and albitic borders, and usually decoloured biotite; ii) Alpine, with mylonitic features and greenschist facies: quartz-2, microcline, albite, greenish biotite- $2 \pm$ epidote, and sericite, followed by the static growth of phrenite, chlorite \pm albite and epidote. The frequent cataclastic structure of quartz and other magmatic crystals, within a fine matrix of quartz and albite, was due to the dynamic recrystallisation and cataclasis of primary minerals. The tectono-metamorphic foliation described in the Italian part by Baggio and Malaroda is not reported, except in the contact zone between the granite and schists, noted by Gudefin \& Vitel (1971). The pegmatitic dykes associated with the main intrusive mass contain primary white mica and tourmaline.

\section{EPILOGUE}

Since Roman age, people living on both sides of the Alps had been seeking different 'north-west passages', first overriding the mountains and then moving under them. Tunnelling of the chain has been a journey in both space and time, exploring the great collisional suture that has brought closer and than sewed Africa and Europe through geological eras.

In the year 2020, during the age of globalization, the COVID-19 pandemy has suddenly erected invisible, but impenetrable, barriers to worldwide connections. Our freedom to move has quickly and strongly been restricted for health and safety reasons. Thus, Homo Sapiens sapiens is nowadays enforced once again to change perspective on its presence as temporary guest on planet Earth.

Hoping this continental (and local) separation should be only temporary, we presented in this paper a storytelling of the scientific and technological challenge of crossing the Alps, going down through the natural barricades. In our thinking, especially in times of physical separation, the transalpine tunnels enterprises take on a particular meaning: every man involved, directly nor indirectly, in excavating in the bowels of the Earth - from Kings and Presidents, to engineers, geologists, surveyors and workmen - has been, somehow, a modern Ulysses crossing the Pillars of Hercules.

Among all stories we have briefly but faithfully presented in this paper, some of them deserve a special mention: i) the innovative geological projects conceived in the last decades of the $19^{\text {th }}$ century by Felice Giordano and Martino Baretti and, at the century turn, by Franchi, Kilian and Jacob, for the Gothard and Mont Blanc railway tunnels, the first drilled, the last not; ii) the geological contributions of Paolo Baggio and Roberto Malaroda to the Mont Blanc road tunnel, supported by the field and underground survey of Giuseppe 'Gè' Mezzacasa during excavation works.

The macro- and microscopic descriptions which Baggio and Malaroda published between 1958 and 1964 had reinterpreted the granite and its metamorphic derivatives of the 'intrusive nucleus' of Mont Blanc as various types of embrechite, anatexite and microgranular aplitic granite, based on the petrogenetic doctrine of dominant metasomatic processes.

In reality, as documented partly in previous literature and extensively in modern works, these were: i) the large idiomorphic potassic feldspars of the protogine are not phenoblasts produced by metasomatic fluids, but phenocrystals of an igneous granite which intruded into the complex of older paraschists and migmatite which forms the roof of the Late Carboniferous batholith (313 $\mathrm{Ma})$; ii) the various types of embrechite described in the tunnel are not derived from the metasomatism of ancient paragneisses, nor are they prodromes of anatectic granite, but varieties from weakly foliated, cataclastic, gneissic or mylonitic types of the granite itself, as a 
combined effect of the Permian extension, Mesozoic continental rifting and Alpine tectono-metamorphic overprint; iii) the aggregates of fine-grain quartz are not the only result of hydrothermal activity, which was also abundant, younger, but with different characteristics: they are also due to the dynamic re-crystallisation of large crystals of magmatic quartz; iv) brittle initial deformations, followed by ductile shear zones, often associated with quartz, albite, biotite, chlorite and zeolite, in turn followed by later brittle deformation.

As a whole, these processes characterise the Alpine evolution of the granitic body and its neogenic exhumation (e.g., Guermani \& Pennacchioni, 1988; Rolland et alii, 2008; Glotzbach et alii, 2011; Egli \& Mancktelow, 2013; Egli et alii 2017). In spite of the metasomatic interpretation, the high quality and detail of the geological survey by Baggio and Mezzacasa on the surface and by Mezzacasa in the tunnel must be confirmed and emphasised, and particularly the representation in the maps and graphs of the various features of deformation. Giuseppe Mezzacasa had been a sort of 'ghostwriter', because at that time technical personnel was rarely involved in scientific publications and his contribution is only quoted in short footnotes. Time has come, six decades after, to recognize him the merit of having been a protagonist, and not only a minor character, of the unraveling the Mont Blanc hidden secrets.

It is worth to note that the progress of transalpine tunnelling walked alongside to the evolution of geological understanding of the Alps. Geological knowledge and applications are fundamental tools for carrying out subsurface engineering works, guiding land planning and projects' design. The facts we described witness how loss of time, money and human lives can be often related to political and technical choices not adequately supported by geological studies and field survey. The historical Gottardo's case is the first emblematic example, due to the forward-looking vision and skills of the engineergeologist Felice Giordano, following his friend Quintino Sella to be fully aware, at the end of $19^{\text {th }}$ century, of the importance of step-by-step geological mapping and structural analysis for great works.

We hope that this article could represent a tribute to and lift the oblivion veil over all scientist and technicians that, by means of geological studies, surveys, maps and sections, allowed mountains to be metaphorically transparent, thus making it easier and safer to physically pass through them.

\section{AcKNowledgements}

We wish to dedicate this article to the memory of Paolo Baggio and Giuseppe Mezzacasa.

Management and library staff of the Accademia Nazionale dei Lincei, Accademia Nazionale delle Scienze detta dei XL, Accademia Nazionale delle Scienze di Torino, Istituto Veneto di Scienze Lettere ed Arti, Servizio Geologico d'Italia (ISPRA), Dipartimento di Geoscienze of the University of Padova, as well as the Bibliothèque nationale de France, are warmly thanked for referencing and reproduction of historical documents, maps and sections. Annalaura Pistarino kindly provided original news on sample collections, photographs and geological documents on the Mont Blanc tunnel, presently kept by the Museo Regionale di Scienze Naturali di Torino. Renata Mezzacasa told us valuable news about her husband Giuseppe, his work and their stay in Cormayeur during excavation of the tunnel. The colleagues D. Bernoulli, A. Borghi, A.M. Chiorino,
D. Cosentino, G. Godard, G. Mortara, C. Rosenberg, F.M. Petti and M. Sella are acknowledged for documents, discussions and fruitful suggestions. S. Pelizza kindly provided his presentation on Piemonte cross-alpine tunnels to the WTC 2019. The authors also thank Gabriel Walton for her support in improving the English version of the manuscript. The manuscript benefited from accurate comments and suggestions by G.B. Vai, an anonymous reviewer and the Associate Editor.

\section{REFERENCES}

Alaria P. (1976) - Cantiere Monte Bianco. Operazioni topografiche per il tracciamento della galleria e un po' di storia del tunnel secondo le memorie del topografo: anni 1946-1965. Ed. Collegio dei Geometri di Torino e Provincia, $468 \mathrm{pp}$.

ARGAND E. (1909) - L'exploration géologique des Alpes pennines centrales. Bull. Soc. Vaudoise Sci. nat., 45, 217-276.

Argand E. (1911) - Les Nappes de recouvrement des Alpes Pennines et leur prolongement structuraux. Mat. Carte géol. Suisse, N.S. 31-26.

ARTini E. \& MELzi G. (1900) - Ricerche petrografiche e geologiche sulla Valsesia. Mem. R. Istituto Lombardo Sci. Lett., 18, 219-390.

BAGGIo P. (1958) - Il granito del Monte Bianco e le sue mineralizzazioni uranifere. Studi ricerche Divisione geomineraria CNEN, 1, 3-128.

BAGgio P. (1964) - Contributo alla conoscenza geologica del versante italiano del Monte Bianco. Atti Istituto Veneto Sci. Lett. Arti, 122, 293-325.

Baggio P. \& Malaroda R. (1961) - Il traforo del Monte Bianco: prime osservazioni sul tratto dalla progressiva 1300 alla progressiva 2500 (parte italiana). Rend. Acc. Naz. Lincei, 30(6), 909-929.

Baggio P. \& Malaroda R. (1962) - Il traforo del Monte Bianco: prime osservazioni sul tratto dalla progressiva 2500 alla progressiva 3700 (parte italiana). Rend. Acc. Naz. Lincei, 33(3/4), 149-152.

Baggio P. \& MaLARoda R. (1963) - I tipi Iitologici incontrati nella parte italiana del traforo del Monte Bianco tra la progressiva 2500 e 3700. Rend. Acc. Naz. Lincei, 34(3), 293-298.

Baggio P. \& Malaroda R. (1964a) - Il traforo del Monte Bianco: prime osservazioni geologiche sul tratto dalla progressiva 3700 alla progressiva 4900 (parte italiana). Rend. Acc. Naz. Lincei, 36(6), 858-864.

Baggio P. \& Malaroda R. (1964b) - Il traforo del Monte Bianco: prime osservazioni sul tratto dalla progressiva 4900 alla progressiva 5800. Rend. Acc. Naz. Lincei, 37(3-4), 118-122.

Baggio P. \& Mezzacasa G. (1971) - Carta geologica della zona tra la Brenva e T. Jetoula (Massiccio del Monte Bianco). STEM Mucchi, Modena.

Baggio P., Elter G. \& Malaroda R. (1960) - Il traforo del Monte Bianco: prime osservazioni geologiche sul tratto dall'imbocco alla progressiva 1300. Rend. Acc. Naz. Lincei, 28, 470-476.

Baggio P., Ferrara G. \& Malaroda R. (1967) - Results of some $\mathrm{Rb} / \mathrm{Sr}$ age determinations of the rocks of the Mont Blanc tunnel. Boll. Soc. Geol. It., 86, 193-212.

Baldacci L. \& Franchi S. (1900) - Studio geologico della Galleria del Colle di Tenda (Linea Cuneo-Ventimiglia). Boll. R. Comitato Geol. d'Italia, 31, 33-87, carta geol. 1:50.000 e profilo geol. 1:25.000.

Barale L., Mosca P. \& Fioraso G. (2018) - Il "periodo d'oro" degli studi geologici nelle Alpi Marittime tra il XIX e il XX secolo. Rend. Online Soc. Geol. It., 44, 64-71.

Baretti M. (1881) - Apercu géologique sur la Chaine du Mont Blanc en rapport avec le traject probable d'un tunnel pour la nouvelle ligne de chemin de fer. Mem. Comité local d'Aoste promoteur de la percée du Mont Blanc, J. Candeletti Editeur-Imprimeur, Turin, 38 pp. Esquisse géognostique.

Baretti M. (1893) - Geologia della Provincia di Torino. Casanova, Torino, $732 \mathrm{pp}$.

Baretti M., Bruno C., Bruno L., Gastaldi B. \& Gerlach H. (1860 1879) - Gran Carta degli Stati Sardi in Terraferma (Carta Geologica delle Alpi Piemontesi o delle Alpi Occidentali). 29 Fogli alla scala 1:50.000, disegnati a mano.

Bellière J. (1958) - Contribution à l'étude pétrogénetique des schistes cristallins du mssif des Aiguilles Rouges (Haute Savoie). Annales Societé Géol. Belgique, 81, 1-198.

Bertoglio G. \& Chabod R. (1966) - Due trafori. Rivista mensile Club Alpino Italiano, anno 87 (3), LXXXV, 3-21. 
Biadego G.B. (1906) - I grandi trafori alpini Fréjus, San Gottardo, Sempione ed altre gallerie eseguite a perforazione meccanica. Ulrico Hoepli Editore, Milano, 2 vol., 1228 pp.

Bibolini A. (1946) - Note geologiche-geognostiche inerenti al traforo del Monte Bianco. Relazione inedita, Torino.

Bigi G., Castellarin A., Coli M., Dal Piaz G.V., Sartori R., Scandone P. \& VAI G.B. (1990) - Structural Model of Italy scale 1:500.000, sheet 1. CNR. Progetto Finalizzato Geodinamica, SELCA Firenze.

Bignami E. (1861) - Cenisio e Fréjus con una lettera del Generale Menabrea. G. Barbera Editore, 349 pp. e carta speciale del Cenisio.

Blès J.L. aVec la collaboration de D. Bonijoly (1983) - Contract $n$. 148-80-7 WAS-F (RS) Fracturation profonde des massifs rocheux granitiques. Etude documentaire. Rapport B.R.G.M. 83 SGN 858 GEO, 53 pp.

Bonelli J. (1880) - Projet d'un chemin de fer international à faibles pentes à travers les Apennins et les Alpes par la chaine du MontBlanc offrant le double avantage de relier la Ligurie à Geneve ou directement l'Italie à la France. Imprimerie franco-italienne, Torino, 56 pp., avec planimetrie, profil géneéral de la ligne et coupe trasversale du groupe du Mont-Blanc.

Bordet C. (1961) - Recherches géologiques sur la partie septentrionale du massif de Belledonne (Alpes francaises). Mém. Serv. Carte géol. France, 22, 218 pp.

Borghi A., Gallo L.M. \& Porro A. (1987) - Osservazioni petrografiche nel settore francese del traforo del Monte Bianco. Boll. Museo Regionale Sci. Nat. Torino, 5(1), 69-96.

Bortolami G.C., Fontes J.Ch., Lale Demoz D., Olive Ph., Quijano L. \& ZuPPI G.M. (1979) - Infiltration rate through the crystalline massif of Mont-Blanc evidenced by environmenttal isotope measurements. Proceeding of Work-shop on low-flow, low-permeability measurements in largely impermeable rocks, O.E.C.D. - I.A.E.A., 237-247.

Burri M. \& Marro C., aVec la contribution de F. Bussy (1993) - Atlas géologique de la Suisse 1:25 000, Feuille 1345 Orsières, Notice explicative. Service hydrologique et géologique national, $75 \mathrm{pp}$.

Bussy F. \& von Raumer J. (1994) - U-Pb geochronology of Palaeozoic magmatic events in the Mont-Blanc crystalline massif, Western Alps. Schweiz. Mineral. Petrogr. Mitt., 74, 514-515.

Campanino F. \& Polino R. (2002) - Carta geologica delle Alpi Piemontesi (1860-1879 ca.). Fotomosaico al 1:380.000 dei 29 fogli al 1:50.000 rilevati da $M$. Baretti, $B$. Gastaldi, $H$. Gerlach, con la collaborazione di C. Bruno, L. Bruno e G. Michelotti. Regione Piemonte, Museo Regionale Sci. Nat. di Torino, Litografia Geda, Nichelino.

CARETta U. (1967) - Studi sulle acque scaturite nel tratto italiano della Galleria del Monte Bianco. Atti Istituto Veneto Sci. Lett. Arti, Cl. Sci mat. nat., 125, 391-413.

Castiglia C. \& Chiorino M.A. (1967) - L'impalcato stradale del traforo del Monte Bianco. La Rivista della Strada, XXXVI, n. 309, 447-470.

Cavinato G.P., Di Luzio E., Moscatelli M., Vallone R., Averardi M., Valente A. \& Papale S. (2006) - The new Col di Tenda tunnel between Italy and France: Integrated geological investigations and geophysical prospections for preliminary studies on the Italian side. Engineering Geology, 88, 90-109.

Cena F. (1952) - Galleria autostradale sotto il Col Ferret. Cronache Economiche, Camera di Commercio, Industria e Agricoltura di Torino, 120(12), 23-29.

Chabrand E. (1910) - Le Pertuis du Viso lla plus ancienne trouée souterraine des Alpes): la légende et l'histoire. Ed. Xavier Drevet.

CIALdini P. (2011) - Frejus. Storia del primo traforo delle Alpi e degli uomini che lo realizzarono 1871-2011. Ministero Infrastrutture e Trasporti, $79 \mathrm{pp}$.

CiтA M.B. (1953) - Studi geologici sulla Val Ferret italiana (Alta Val d'Aosta). Boll. Servizio Geol. d'Italia, 65, 66-172.

Colladon D. (1880) - Notes sur les inconvénients et les difficultés du tunnem étudié sous le Mont-Blanc et de ses lignes d'accès projetées. Advantage incontestable d'un chemin de fer international par le Simplon. A. Druin libr., Paris, 79 pp.

Collet L.W. (1924) - Description générale du Massif du Mont-Blanc 2: Aperçu sur la géologie du Mont Blanc et des Aiguilles Rouges. Librairie Fischbacher, Paris, 51 pp.

Collet L.W. (1927) - The Structure of the Alps. Edward Arnold \& Co., London, 289 pp.

Collotti E. \& Collotti Pischel E. (1974) - La storia contemporanea attraverso $i$ documenti. Zanichelli, Bologna, 352 pp.
Compagnoni R., Elter G. \& Sturani C. (1964) - Segnalazione di Albiano fossilifero nel tratto valdostano della zona delfinese-elvetica. Rend. Acc. Naz. Lincei, 36, 391-394.

Console F. (2016) - 1872: Felice Giordano e la Carta Geologica del San Gottardo. Geoitaliani. https:/www.geoitaliani.it/2016/01/ gottardo.html

Conte M. (1863) - Rapport sur le percement du grand tunnel des Alpes. Dunod Editeur, Paris, 51 pp.

Corbin P. \& Oulianoff N. (1927-1959) - Carte géologique du Massif du Mont-Blanc à l'échelle du 1/20.000, avec notes explicatives: Feuilles Servoz-Les-Houches (1927), Chamonix (1928), Les Tins (1929), Vallorcine (1930), Le Tour (1931), Argentières (1932), Mt. Dolent (1934), Talèfre (1935), Mt Blanc sommet (1952), Aiguilles du Midi (1954), Miage (1959).

Corbin P. \& Oulianoff N. (1930) - Observations sur le metamorphisme de contact produit par la protogine du Mont-Blanc. Bull. Soc. géol. France, 30, 563-570.

Consi P. (2018) - Sommeiller, Germain. Dizionario biografico degli Italiani, v. 93

Dal Piaz G.B. \& Dal Piaz G.V. (1984) - Sviluppo delle concezioni faldistiche nell'interpretazione tettonica delle Alpi (1840-1940). Soc. Geologica Italiana, vol. giubilare $1^{\circ}$ centenario, PitagoraTecnoprint Bologna, 41-70.

Dal Piaz G.V. (1992) - Le Alpi dal M. Bianco al Lago Maggiore. Volume I: 13 itinerari. Guide Geol. Regionali, Soc. Geol. It., BE-MA Milano $311 \mathrm{pp}$.

DAL Piaz G.V. (1996) - Felice Giordano and the geology of the Matterhorn. Atti Acc. Sci. Torino, 130, 163-179.

DAL PIAZ G.V. (2013) - Risorse e montagna: il territorio nella politica scientifica. Atti Convegni Lincei: Quintino Sella scienziato e statista per l'Unità d'Italia, Roma, 5-6 Dicembre 2011, 269, 113-143.

Dal PIAZ G.V. (2018) - Felice Ippolito, il Comitato Nazionale per le Ricerche Nucleari e la ricerca di minerali radioattivi nel basamento cristallino delle Alpi. Rend. Online Soc. Geol. It., 44, 30-36.

Dal Piaz G.V. \& Argentieri A. (2019) - Sessant'anni del Traforo del Monte Bianco, la storia di una impresa. Prologo: da Annibale alle grandi gallerie alpine. Acque Sotterranee. Italian Journal of Groundwater, AS30-404, 75-81.

Dal Piaz G.V., Bistacchi A., Gianotti F., Monopoli B., Passeri L. con la collaborazione di Bertolo D., Bonetto F., Ciarapica G., Dal Piaz G., Gouffon Y., Massironi M., Ratto S., Schiavo A. \& Toffolon G. (2015) - Carta Geologica d'Italia alla scala 1:50.000: foglio 070 Monte Cervino e Note illustrative. APAT, Regione Autonoma Valle d'Aosta, 431 pp., e Mem. descrittive Carta Geol. d'Italia, ISPRA Servizio Geol. d'Italia, 101, $272 \mathrm{pp}$.

De Giusti F., Dal Piaz G.V., Massironi M. \& Schiavo A. (2004) - Carta geotettonica della Valle d'Aosta alla scala 1:150.000. Mem. Sci. Geol., 55(2003), 129-149.

Duc G. (2001) - Project de tunnel ferroviaire du Simplon et geneèse du réseau de chemins de fer de Suisse occidentale (1836-1909). In C. Humair: Aux sources du succès hydroélectrique suisse: l'introduction de l'éclairage internationales et trajectoires des compagnies privées. Valesia, 56, 495-617.

Dufrénoy A. \& Elie de Beaumont L. (1840) - Carte géologique de la France 1:500.000. Serv. Carte géol. France.

Dufrénoy A. \& Elie de Beaumont L. (1841) - Explication de la Carte géologique de la France. Serv. Carte géol. France, Tome premier.

Duparc L. \& Mrazek L. avec la collaboration de Pearce F. (1896). Carte géologique du Massif du Mont-Blanc. Scale 1:50.000, Levée de 1890-1896, Genève.

DuPARc L. \& MrazeK L. (1898)-Recherches gèologiques et pétrographiques sur le Massif du Mont-Blanc. Mém. Soc. Phys. Hist. Nat. Genève 33(1), $227 \mathrm{pp}$.

Egli D. \& Mancktelow N. (2013) - The structural history of the Mont Blanc massif with regard to models for its recent exhumation. Swiss J. Geosci., 106, 469-489.

Egli D., Mancktelow N. \& Spikings R. (2017) - Constraints from 40Ar/39Ar geochronology on the timing of Alpine shear zones in the Mont Blanc-Aiguilles Rouges region of the European Alps Tectonics, 36. https://doi.org/10.1002/2016TC004450

Elie de Beaumont L. (1871 a) - Sur les roches qu'on a rencontrées dans le creusement du tunnel des Alpes occidentales, entre Modane et Bardonnèche. C.R. des séances de l'Académie des Sciences, t. LXXI et LXXIII, séances 4 juillet 1870 et 18 septembre 1871,42 pp. 
Elie de Beaumont L. (1871 b) - Geologie des Alpes et du tunnel des Alpes. Actualités scientifiques publiées par M. l'Abbé Moigno, M. Gauthier-Villars, Imprimeur-Libraire, Paris, 1-70.

Elter G. (1953) - Sul rilevamento geologico di alcune zone dei fogli 27 (Monte Bianco) e 28 (Aosta). Boll. Servizio Geol. d'It., 75, 692-698.

Elter G. (1954) - Osservazioni geologiche nella regione di Courmayeur (alta Valle d'Aosta). Pubbl. Istituto Geologia Univ. Torino, 2, 85-93.

Elter G. (1955) - Nuovi risultati del rilevamento dei fogli Monte Bianco e Aosta. Boll. Serv. Geol. d'It., 76, 477-479.

Elter G. \& Elter P. (1965) - Carta geologica della regione del Piccolo S. Bernardo (versante italiano). Note illustrative. Mem. Istituti Geol. Min. Univ. Padova, 25, 53 pp.

EPARD J. L. (1989) - Stratigraphie du Trias et du Lias dauphinois entre Belledonne, Aiguilles Rouges et Mont-Blanc. Boll. Soc. Vaudoise Sci. nat., 79(4), 301-338.

Favre A. (1862) - Carte géologique des parties de la Savoie, du Piémont et de la Suisse, voisines du Mont-Blanc par Alphonse Favre Professeur de Géologie à l'Academie de Genève, échelle 1/150.000. Gravure et impression J. Wurster et C.ie, Winterthur.

FAVRe A. (1867 a) - Recherches géologiques dans les parties de la Savoie, du Piémont et de la Suisse voisines du Mont-Blanc. Vol. I, 464 p.; vol. II, 437 p.; vol. III, 587 p., Masson et Fils Editeurs, Paris.

FAVRE A. (1867 b) - Recherches géologiques dans les parties de la Savoie, du Piémont et de la Suisse voisines du Mont-Blanc. Atlas: 32 Planches. Masson et Fils Editeurs, Paris.

Fontes J.CH., Bortolami G.C. \& Zuppi G.M. (1979) - Hydrologie isotopique du massif $d u$ Mont-Blanc. Isotope Hydrology, vol. 1, I.A.E.A., Vienna, 411-440.

FORBES J.D. (1843) - Travels through the Alps of Savoy and other parts of the Pennine chain with observations of the phenomena of glaciers. Adam and Charles Black, Edinburgh, 424 pp.

Franceschetti G. (1960) - Manifestazioni metallifere nel granito del $M$. Bianco e negli scisti incassanti (versante italiano). Studi ricerche Divisione geomineraria CNEN, 3, 105-136, carta 1:50.000.

FRANCHI S. (1898) - Sull'età mesozoica della zona delle pietre verdi nelle Alpi Occidentali. Boll. R. Comitato Geol. d'Italia, 29, 173-247 e 325-482.

FRANCHI S. (1899) - Nuove località con fossili mesozoici nella zona delle pietre verdi presso il Colle del Piccolo San Bernardo (Valle d'Aosta). Boll. R. Comitato Geol. d'Italia, 30, 303-324.

Franchi S. (1901) - Rilevamenti geologici del 1900-1901. Boll. R. Comitato Geol. d'Italia, 32, 35-39, parte ufficiale.

FRANCHI S. (1899) - Nuove località con fossili mesozoici nella zona delle pietre verdi presso il Colle del Piccolo S. Bernardo (Valle d'Aosta). Boll. R. Comitato Geol. d'Italia, 30(4), 303-324.

Franchi S. (1906) - Sulla tettonica della zona del Piemonte. Boll. R. Comitato Geol. d'Italia, 37, 118-144.

FRANCHI S. (1907) - Relazione sulle excursioni in Valle d'Aosta (12 13 settembre 1907) della Societa geologica italiana. Boll. Soc. Geol. It., 26(1), 157-187.

Franchi S. \& Stella A. (1912) - Foglio Monte Bianco. Carta Geologica d'Italia alla scala 1:100.000.

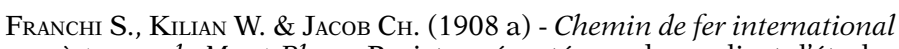
à travers le Mont-Blanc. Projets présentés par le syndicat d'études du tunnel du Mont-Blanc et de ses voies d'accès. I) Rapport géologique sur les projets de tunnels (...) par M.M. Secondo Franchi, W. Kilian et Ch. Jacob, II) Etude géologique de la zone des rampes d'accès d'Aoste aux tunnels du Mont Blanc par M. Secondo Franchi. III) Etude sur la rampe d'accès des tunnels du Mont Blanc entre Oex et Chamonix par W. Kilian et Ch. Jacob.

Franchi S., Kilian W. \& Lory P. (1908b) - Sur les rapports des Schistes lustrés avec les facies dauphinois et brianconnais du Lias. B.C.G.F., 119, XVIII, 119 (1907-1908), 135-141.

Gallo L.M. (2004) - Le collezioni geologiche e litologiche del Museo di Geologia e Paleontologia dell Università di Torino. Museo Regionale Sci. Nat., Torino, $288 \mathrm{pp}$.

Gallo L.M. (2008) - Le collezioni geologiche e litologiche del Museo di Geologia e Paleontologia dell'Università: dalle origini al Museo Regionale di Scienze Naturali di Torino. Memorie Museologia scientifica, 2, 59-64.

GASTALDI B. (1871) - Brevi cenni intorno ai terreni attraversati dalla galleria delle Alpi Cozie. Boll. R. Comitato Geol. d'Italia., 1871 (910), $198 \mathrm{pp}$.
Gastaldi B. (1872) - Cenni sulla costituzione geologica del Piemonte. Boll. R. Comitato Geol. d'Italia, 3(1-2), 14-32 (estratto da nota pubblicata nella Enciclopedia Agraria Italiana).

Gerlach H. (1869) - Die Penninischen Alpen. N. Denkschr. allg. schweiz. Ges. Naturwiss, 23, 1-132, mit Karte der Penninischen Alpen, 1:200.000.

GioRdano F. (1871) - Sulla temperatura della roccia nella Galleria delle Alpi Cozie (detta volgarmente del Cenisio). Boll. R. Comitato Geol. d'Italia, 1871 (1-2), Gennaio-Febbraio 1871, 1-63.

GioRdANO F. (1872) - Esame geologico della catena alpina del San Gottardo che deve essere attraversata dalla Grande Galleria della Ferrovia italo-elvetica. Firenze, Tipografia G. Barbera, 33 pp., Carta geologica del San Gottardo 1:50.000.

GioRdano F. (1873) - Esame geologico della catena alpina del San Gottardo che deve essere attraversata dalla grande galleria della ferrovia italo-elvetica. Mem. per servire alla descrizione della Carta Geol. d'Italia, a cura R. Comitato Geol. del Regno, 2 (1) 63-93, carta 1:50.000.

Glotzbach C., Reinecker J., Danišík M., Rahn M., Frisch W. \& SPIEgEl C. (2008) - Neogene exhumation history of the Mont Blanc massif, western Alps. Tectonics, 27, TC4011. https://doi. org/10.1029/2008TC002257

Glotzbach C., VAN der Beek P.A. \& SPIEgel C. (2011) - Episodic exhumation and relief growth in the Mont Blanc massif. Western Alps from numerical modelling of thermochronology data. Earth Planet. Sci. Letters, 304, 417-430.

Gonella F., Silvano E. \& Coggiola E. (1906) - Da Courmayeur a Martigny, strada rotabile. Tipografia G.U. Cassone, succ. G. Candeletti, Torino aprile 1906, 36 pp., 3 tav.

Grandis S., Grattoni S. \& Sommeiller G. (1863) - Traforo delle Alpi tra Bardonneché e Modane. Relazione della Direzione Tecnica alla Direzione Generale delle Strade Ferrate dello Stato, Torino.

Gudefin H. (1967) - Observations sur les venues d'eau au cours du percement du tunnel sous le Mont-Blanc. Bull. B.R.G.M., 4, 95107.

Gudefin H. \& Vitel G. (1970) - Observations géologiques et géotechniques sur la partie française du tunnel sous le Mont-Blanc (Alpes occidentales). Rapport B.R.G.M. n 70 SGN 322 JAL, 67 pp.

Guermani A. \& Pennacchioni G. (1998) - Brittle precursors of plastic deformation in a granite: an example from the Mont Blanc massif (Helvetic, western Alps). J. Struct. Geology, 20, 135-148.

Guichonnet P. (1952) - Le project de tunnel routier sous le Mont-Blanc. Revue Géographie Alpine, 40(2), 329-347.

Guichonnet P. \& Bernieri U. (1963) - Historique de la percée du Mont-Blanc. (Les Précurseurs) Première partie 1814-1945. Aosta, Imprimerie Valdotaine, 85 pp, 24 tav. f.t.

Guntli P., Keller F., Lucchini R. \& Rust S. (2016)-Gotthard-Basistunnel: geologie, Geotechnik, Hydogeologie - zusammenfassender Schlussbericht. Rapports du Service géologique national, 7, 180 pp.

HeIm A. (1878) - Untersuchungen über den Mechanismus der Gebirgsbildung im Anschluss an die geologische Monographie der Tödi-Windgällen-Gruppe. Benno Schwabe Verlags., Basel.

Hегм A. (1904) - Ueber die geologische Voraussicht beim Simplontunnel. Eclogae Geol. Helv., 4, 365-384.

JANIN B. (1962) - Les tunnels routiers du Mont-Blanc et du Grand-SaintBernard, les perspectives de leur ouverture pour la vallée d'Aoste. Revue Géographie Alpine, 50, 87-120.

Jelmoni F.A. (1948) - La Galleria del Gran San Bernardo per l'itinerario Svizzera-Torino-Mare. Relazione tecnica orientativa. Compagnia Aosta-Martigny. Unione Tipografica, Milano, 47 pp.

Jung J. \& Roques M. (1952) - Introduction à l'étude zonéographique des formations cristallophylliennes. Bull. Serv. Carte géol. France, n. 235, 50, 1-61.

JuRINE L. (1806) - Lettre à Monsiur Gillet-Laumont. Journal des Mines, 19, 113, 367-378.

Laporte P. (1963) - Le tunnel du Mont Blanc. Annuaire Français de Droit International, 9, 259-277.

Lapparent A., DE (1883) - Traité de Géologie. F. Savy, Paris.

Liechti H. (1934) - Sur la tectonique de la 'protogine' du massif du Mont-Blanc. Schweiz. Mineral. Petrogr. Mitt., 14, 176-195.

Lesca C. (1993) - Il primo traforo delle Alpi. Tecnica e storia. Strade Ferrate del Piemonte, Politecnico di Torino, 177-199. 
LESCA C. (1998) - Tre ingegneri per un traforo. La storia della ferrovia del Frejus. Editrice Melli, Borgone di Susa-Torino, $181 \mathrm{pp}$.

LoRy C. (1846) - Etudes sur les terrains secondaires des Alpes dans les environs de Grenoble. Thèse, Faculté des Sciences, Paris.

Lory C. (1857) - Esquisse d'une carte géologique du Dauphiné. Bull. Soc. géol. France, 2e série, Seance du 2 novembre 1957, 15, 10-69.

Lory C. (1858) - Carte géologique du Dauphiné (Isère, Droôme, Hautes-Alpes) 1:250.000, par M. Ch. Lory, professeur de géologie à la Faculté des sciences de Grenoble. A. Merle et Cie LibrairesEditeurs, Grenoble. Bibl. patrim. numérique de l'École nationale supérieure des mines de Paris (Mines ParisTech).

Lory C. (1860) - Description géologique du Dauphiné (Isère, Droôme, Hautes-Alpes) pour servir à l'explication de la Carte géologique de cette province. Savy, Paris, $747 \mathrm{pp}$.

Lory C., Piller L. \& Vallet P. (1869) - Carte géologique du département de la Savoie, échelle 1:150.000. Lithographie A. Perrin, Chamberry.

Lugeon M. (1902) - Sur la coupe géologique du massif du Simplon. Comptes-rendus séances de l'Acad. d. Science., Paris 24 mars

LugEON M. \& ARGAND E. (1905) - Sur les grandes nappes de recouvrement de la Zone du Piémont. C.R. Acad. Science Paris, 140, 1364-1367.

Malaroda R. \& Schiavinato G. (1958) - Le Anatessiti dell'Argentera. Rend. Soc. Min. It., 14, 249-274.

Masson H. (1983) - La géologie en Suisse de 1882 à 1932. Eclogae Geol. Helv., 76, 47-64.

Maus H. J. M. (1850 a) - Relazione del Cavaliere Enrico Maus sugli studi da lui fatti della strada ferrata da Chambéry a Torino e sulla macchina da lui proposta per il perforamento dell'Alpi fra Modane e Bardonnèche (p. 1-34), e Rapporto dell'Ispettore Cavaliere Pietro Paleocapa fattane alla Commissione incaricata dell'esame (p. 3550) coi Processi verbali della Commissione medesima (p. 51-56), Stamperia Reale, Torino 1850, original from Harvard University.

Maus H. J. M. (1850 b) - Rapport sur les études du chemin de fer de Chambéry à Turin et de la machine proposée pour exécuter le tunnel des Alpes entre Modane et Bardonnèche par le Chevalier Henri Maus et Rapport rédigé au nom de la commission chargée de l'examen de ces études par le Chevalier Pierre Paleocapa; suivi des procèsverbaux des séances de cette commission. Imprimerie Royale, Turin, $56 \mathrm{pp}$.

Maus H.J.M. (1850 c) - Strada ferrata fra l'Italia e la Francia: risposta alle osservazioni state fatte sulla conferenza, la scelta del tracciamento, ed $i$ mezzi d'esecuzione della strada ferrata da Torino al confine francese presso il lago del Bourget di H. Maus. Stamperia reale, Torino, 62, $7 \mathrm{p}$

Medail J.F. (1841) - Projet de percement des Alpes entre Bardonneche et Modane. Imprimerie Dumoulin, Ronet et Sibuet, Lyon, 16 pp.

Michel-Levy M. (1890) - Etudes sur les roches cristallines et eruptives du Mont Blanc. Bull. Carte géol. France, 9, 1-54.

Michel-Levy M. (1928) - Sericitoschistes des chaines du Mont-Blanc et des Aiguilles Rouges qui sont des mylonites recristallisées postérieurs au granite. Bull. Soc. géol. France, ser. 4., 28, 255-260.

Milnes A.G. (1973) - Structural interpretation of the classic Simplon Tunnel section of the Central Alps. Geol. Soc. Am. Bull., 64, 269274.

Mortillet G., DE (1872) - Géologie du tunnel de Fréjus ou percée du Mont-Cénis. Revue savoisienne, Imprimerie A. Perrissin, Annecy, $16 \mathrm{pp}$.

Mrazec L. (1892) - La protogine du Mont-Blanc et les roches éruptives qui l'accompagnent. Thèse de Pétrographie pour Docteur-enSciences, Fac. Sciences, Univ. Genève, G. Georg Editeur, Genève, $89 \mathrm{pp}$.

Oberhänsti R., Bousquet R., Engi M., Goffé B., Gosso G., Handy M., Höck V., Koller F., Lardeaux J. M., Poliano R. Rossi P., Schuster R., Schwarz S. \& Spalla M. (2004). Metamorphic Structure of the Alps (1:1 000 000). Paris: Commission for the Geological Map of the World (UNESCO).

Olivero S. (1962) - Primi dati sulle temperature del sottosuolo nel traforo del Monte Bianco. Rend. Acc. Naz. Lincei, 32, 192-203.

Olivero S. \& Penta F. (1959) - Sulle misure di temperatura nel traforo del Monte Bianco. Rend. Acc. Naz. Lincei, 26, 731-737.

Oulianoff N. \& Trümpy R. (1958) - Feuille du Grand St Bernard et sa notice explicative. Atlas geol. Suisse 1/25.000, Feuille 33, Comm. Géol. Suisse Berne, 39 pp.
Paleocapa P. (1850) - Rapporto fattone alla commissione incaricata dell'esame. In H. Maus: Relazione sugli studi sulla strada ferrata da Chambéry a Torino e sulla macchina proposta per il perforamento delle Alpi fra Modane e Bardonnèche. Stamperia Reale, Torino.

ParéJAS Ed. (1922) - Géologie de la zone de Chamonix comprise entre le Mont-Blanc et les Aiguilles Rouges. Mém. Soc. Phys. Hist. nat. Genève, 39(7), 373-442.

Palmero G. (1872) - Cronaca del Traforo delle Alpi Cozie e memorie di Torino e Bardonecchia nei giorni 17, 18 e 19 Settembre 1871. Eredi Botta, Torino, 207 pp.

Pearce F. (1898) - Recherches sur le versant SE du massif Mont-Blanc. Thèse Univ. Genève, Arch. Sci. Phys. Nat. Genève, 133 pp.

Piatti G.B. (1858) - Il gigantesco traforamento del Monte Cenisio, le macchine che lo operano, e il vero autore del progetto. Giornale dell'ingegnere-architetto ed agronomo, 6, 569-576, 629-644.

Puschnig A.R. \& Graeser S. (2006) - 100 Jahre Simplon-Eisenbahntunnel - Beitrag von Baslern beim Bau des Tunnels und zur Geologie des Simplons. Mitt. Naturforsch. Ges. beider Basel, 9, 67-86.

ReNeVIER E. (1883) - Etude géologique du project du Tunnel coudé au Simplon (en collaboration avec MM. Lory, Heim et Taramelli). Bull. Soc. Vaudoise Sci. nat., 29, 1-28.

Renevier E. (1899) - Etude géologique du Tunnel du Simplon. Eclogae Geol. Helv., 6, 31-35.

Rolland Y., Rossi M., Cox S.F., Corsini M., ManckTelow N.S., Pennacchioni G., Fornari M. \& Boullier A.M. (2008) $-{ }^{40} \mathrm{Ar} /{ }^{39} \mathrm{Ar}$ dating of synkinematic white mica: insights from fluid-rock reaction in low-grade shear zones (Mont Blanc Massif) and constraints on timing of deformation in the NW external Alps. Geological Society, London, Special Publ., 299, 293-315.

Romano S. (1977) - Storia d'Italia dal Risorgimento ai giorni nostri. Longanesi, $90 \mathrm{pp}$.

Ransom P.J.G. (1999) - The Mont Cenis Fell Railway. Twelveheads Press, 92 pp.

ROSENBERG C. (2020) - Alpine sections through time: a mirror of evolving observations and thoughts on the tectonics of the Alps. In N. Bellahsen \& C. Rosenberg (Eds): Geodynamics of the Alps, ISTE Editions.

RouilLER J. F. (1955) - La traversée rouitière des Alpes et le tunnel sous le Mont-Blanc. Le Globe, revue genevoise de Géographie, 94, 19-61.

SANERO E. (1938) - Studi petrografici sulle formazioni granitiche e porfiriche del Monte Chetif. Periodico di Mineralogai, 1938, 161214.

SANero E. (1940) - Studi petrografici sul Massiccio del Monte Bianco. Il granito. R. Accademia d'Italia, Rend. Cl. Sci. fis. mat. nat., ser 7, 1(11), 4 pp.

SCHARDT H. (1903a) - Note sur le profil géologique et la tectonique du Simplon comparés aux travaux antérieurs. Eclogae Geol. Helv., 8(2), 173-200.

SCHARDT H. (1903b) - Note sur le profil geologique et la tectonique du Massif du Simplon suivi d'un rapport supplementaire sur les venues d'eau rencontree dans le Tunnel du Simplon du cote d'Iselle. Imprimerie Cobaz, Lausanne, 40 pp.

SCHARDT H. (1905) - Les résultats scientifiques du percement du tunnel du Simplon: géologie-hydrologie-thermique. Bull. technique Suisse romande, 31(10), 125-128.

SchaRdT H. (1906) - Die modernen Anschaungen über den Bau und die Entstehung des Alpengebirges. Actes, St Gallen, 308-346.

SCHARDT H. (1909) - Coup d'oeuil sur la géologie et la tectonique des Alpes et du Canton du Valais. Bull. Soc. Murithienne du Valais, 35, 246-354.

SснміDт C. (1907) - Ueber die Geologie des Simplongebietes und die Tektonik der Schweizer Alpen. Eclogae Geol. Helv., 9, 484-584.

SснміDт C. (1908) - Die Geologie des Simplongebirges und des Simplontunnels. Rektoratsprogramm der Univ. Basel für 1906 und 1907, Basel.

Schmidt C. \& Preiswerk H. (1908) - Erläuterungen zur geologischen Karte des Simplongruppe. Geol. Karte d. Schweiz, Erläuterungen n. 6.

Schmidt C., Preiswerk H. \& Stella A. (1908) - Geologische Karte der Simplon-Gruppe in 1:50.000. Beitrage zur Geol. der Schweiz, Lief. 26, Spezialkarte n. 48, Geol. Komm. 
SEllari P. (2011) - Uno sguardo alle ferrovie italiane nell'Ottocento postunitario. Studi e Ricerche Socio-Territoriali, Napoli, 1, 99122.

SISMONDA A. (1839) - Osservazioni geologiche e mineralogiche sopra $i$ monti posti tra la Valle d'Aosta e quella di Susa in Piedmonte. Mem. R. Acc. Sci. Torino, 1, 1-42.

Sismonda A. (1845) - Notizie e schiarimenti sulla costituzione delle Alpi Piemontesi. Mem. R. Acc. Sci. Torino, 9, 123 pp.

Sismonda A. (1862-66) - Carta geologica di Savoja, Piemonte e Liguria. Governo di S.M. Vittorio Emanuele II, Re d'Italia.

Sismonda A. (1872) - Observations du commandeur Ange Sismonda a l'article de Gabriel De Mortillet publie dans la Revue Savoisienne sous le titre de Geologie du Tunnel de Frejus ou percee du MontCenis. Comptes rendus Acad. Science Turin, 7, 12 pp.

Sismonda A., Stoppani A. \& GioRdano F. (1865) - Rapporto della Commissione istituita per l'esame geologico delle grandi gallerie progettate attraverso le Alpi Italo-Elvetiche. Boll. Trimestrale Club Alpino di Torino, Tipografia Cassone, Torino, 1865 (3), 35-51. Ristampa inl Boll. Trimestrale del Club Alpino, 1866.

SommeILler G. (1857) - Risposta dell'ingegnere Sommeiller alle accuse mosse dal signor G.B. Piatti contro gli ingegneri Grandis, Grattoni e Sommeiller. Botta, Torino, $60 \mathrm{pp}$.

Sommeiller G., Grattoni S., Grandis S. (1863) - Traforo delle Alpi tra Bardonneche e Modane. Relazione della Direzione Tecnica alla Direzione Generale delle Strade ferrate dello Stato. Tipografia Ceresole e Panizza, Torino.

Stamm E. (1874) - Mémoire sur un Chemin de Fer perçant le Massif du Mont-Blanc et rejoignant la Vallée D'Aoste à l'Haute-Savoie. Présenté à la Société Industrielle de Mulhouse, Seance du 24 Juin 1874. Imprimerie de Vevuve Bader \& Cie., Mulhouse, 33 pp.

Stamm E. (1874) - Ferrovia del Monte Bianco progetto dell'ingegnere Ernesto Stamm, studiato sul luogo colla collaborazione dell'ing. Leone Maimeri. Tipografia del Monitore delle Strade ferrate, Torino, $36 \mathrm{pp}$

StapFF F.M. (1880) - Geologisches Profil des St. Gotthard in der Axe des sgrossen Tunnels waehrend des Baues (1873-1880) aufgenommen. Maasstab 1:25000. Rapports du Conseil général Suisse, Annexe spéciale, Imprimérie C. J. Wiss, Berne, 59 pp.

Steck A., Bigioggero B., Dal Piaz G.V., Escher A., Martinotti G. \& Masson H. (1999) - Carte tectonique des Alpes de Suisse occidentale et des régions avoisinantes, 1:100.000. Serv. hydrol. géol. nat. Carte spéc. n. 123, 4 feuilles.

Stella A. (1901) - Rilevamenti geologici del 1900. Boll. R. Comitato Geol. d'Italia, 36, 39-43, parte ufficiale.

Stella A. (1905) - Il problema geotettonico dell'Ossola e del Sempione. Boll. R. Comitato Geol. d'Italia, 36, 5-41.

Stella A. (1906) - Cenni geologici sulle nuove linee di accesso al Sempione, etc. In Relazione sugli studi e lavori eseguiti dal 1897 al 1905. Soc. Italiana per le Strade Ferrate del Mediterraneo. Tipografia D. Squarci, Roma, 390 pp., album 74 tav.
Stella A. (1927) - Sezioni geologiche attraverso l'alta Valle d'Aosta. R. Ufficio Geologico, Roma.

StUder B. (1851) - Geologie der Schweiz. Erster Band: Mittelzone und südliche Nebenzone der Alpen. Stämpfli \& Schultess, Bern und Zurich, tomo 1, 223 pp.

TAJANi F. (1939) - Storia delle ferrovie italiane. A cento anni dall'apertura della prima linea. Garzanti, Milano, 280 pp.

Thurmann J. (1856) - Essai d'Orographie jurassique. Mém. Inst. Nat. Genevois, 4, $168 \mathrm{pp}$.

TREVES M. (1864) - Sulla perforazione meccanica delle gallerie ferroviarie ed in particolare sul gigantesco traforo delle Alpi Cozie detto del Moncenisio. Saggio storico descrittivo, Tipografia del Commercio, Venezia 1864, 124 pp.

TRÜMPY R. (1951) - Sur les racine helvétiques et les "Schistes lustrés" entre le Rhône et la vallée de Bagnes (région de la Pierre Avoi). Eclogae Geol. Helv., 44, 338-347.

TRÜMPY R. (1952) - Presence probable du Jurassique superieur et du Crétace inferieur au SW du massif du Mont-Blanc. C.R. sommaires des Séances Soc. Géol. France, 1952 (9), 149-151.

VAcCarone L. (1866) - La ferrovia della Valle d'Aosta. Rivista Mensile del Club Alpino Italiano, 5(7), 201-206.

Vaccarone L. (1881) - Le Pertuis du Viso: Étude historique d'après des documents inédits conservés aux archives nationales de Turin. Ed. F. Casanova, Torino, 1881.

Viganò M. (2007) - "Petrus Morettinus tribunus militum". Un ingegnere della Valle Maggia all'estero: Pietro Morettini (1660-1737). Libero Casagrande, Bellinzona.

Vitel G. (1965) - Etude pétrographique du tunnel du Mont-Blanc (Partie francaise) et recherches géologiques complémentaires dans le massif Mont-Blanc-Aiguilles-Rouges. These doct. 3e cycle, Univ. Grenoble, 89 pp.

Whymper E. (1871) - Scrambles amongst the Alps in the Years 1860 1869. John Murray, London, 432 pp.

Zaccagna D. (1888) - Nota sulla Geologia delle Alpi occidentali. Boll. R. Comitato Geol. d' ltalia, Ser. II, 8(11-12), Novembre e Dicembre, 341-417, con due tavole di sezioni e una carta geologica.

Zaccagna D. \& Mattirolo O. (1892) - Riassunto di osservazioni geologiche fatte sul versante occidentale delle Alpi Graie. Boll. R. Comitato Geol. d' ltalia, 23, 175-244 e 311-404.

ZANGERL C., Loew S. \& EBerhardt E. (2006) - Structure, geometry and formation of brittle discontinuities in anisotropic crystalline rocks of the Central Gotthard Massif, Switzerland. Ecloage. Geol. Helv., 99, 271-290.

Zignoli V. (1965) - Il Traforo del Monte Bianco. Autostrade, n. 6 , Giugno 1965, 39 pp.

Zuppi G.M. \& Bortolami G.C. (1982) - Hydrogeology: a privileged field for environmental stable isotopes applications some Italian examples. Rend. SIMP, 38, 1197-1212.

Manuscript received 29 May July 2020; accepted 21 September 2020; published online 25 November 2020; editorial responsibility and handling by M. Frezzotti. 